\title{
TSD-DOSE: A Radiological'Dose Assessment Model for Treatment, Storage, and Disposal Facilities
}

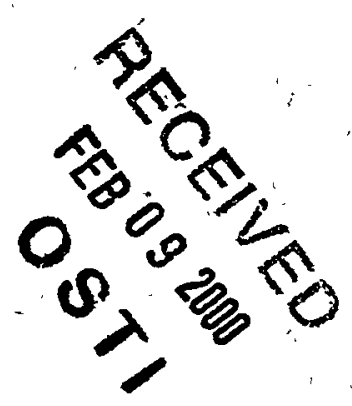

Environmental Assessment Division Árgonne National Laboratory

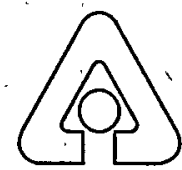

Operated by The University of Chicago, under Contract W-31-109-Eng-38, for the

United States Department of Energy 


\section{Argonne National Laboratory}

Argonne National Laboratory, with facilities in the states of Illinois and Idaho, is owned by the United States Government, and operated by the University of Chicago under the provisions of a contract with the Department of Energy.

This technical memo is a product of Argonne's Environmentál Assessment Division (EAD). For information on the division's scientific and engineering àctivities, contact:

Director, Environmental Assessment Division

Argonne National Laboratory

Argonne, Illinois 60439-4815

Telephione (630) 252-3107

Presented in this technical memo are preliminary results of ongoing work or work that is more limited in scope and depth than that described in formal reports issued by the EAD.

Publishing support services were provided by Argonne's Information and Publishing Division (for more information, see IPD's home page: http://www,ipd.ani.gov/).

\section{Disclaimer}

This report was prepared as an account of work sponsored by an agency of the United States Government. Neither the United States Governiment nor any agency thereof, nor any of their-employees, makes any warranty, express or implied, or assumes any legal liability.or responsibility for the accuracy, completeness, or usefulness of any information, apparatus, product, or process disclosed, or represents that its use would not infringe privately owned rights. 'Reference herein to any specific commercial product, process, or service by trade name, trademark, manufacturer, or otherwise, does not necessarily constitute or imply its endorsement, recommendation, or favoring by the United States Government or any agency thereof. The views and opinions of authors expressed herein do not necessarily state or reflect those of the United States Government or any agency thereof. 


\section{DISCLAIMER}

Portions of this document may be illegible in electronic image products. Images are produced from the best available original document. 


\section{TSD-DOSE: A Radiological Dose Assessment Model for Treatment, Storage, and Disposal Facilities}

by M. Pfingston, J. Arnish, D. LePoire, and S.-Y. Chen

Environmental Assessment Division,

Argonne National Laboratory, 9700 South Cass Avenue, Argonne, Illinois 60439

September 1998

Work sponsored by United States Department of Energy,

Assistant Secretary for Environmental Management 
This report is printed on recycled paper. 


\section{PREFACE}

In May 1991, the U.S. Department of Energy (DOE), Office of Waste Operations, issued a nationwide moratorium on shipping potentially mixed waste (waste with both radioactive and hazardous chemical components) from DOE facilities to commercial treatment, storage, and disposal (TSD) facilities. Studies subsequently were conducted to evaluate the radiological impacts associated with DOE's prior shipments of such materials (Stevens et al. 1995a; Chen et al. 1996). ${ }^{1}$ In March 1997, a radiological assessment computer code - TSD-DOSE (Version 1.1) - was developed to utilize waste-specific and site-specific data to estimate potential radiological doses to on-site workers and the off-site public from waste-handling operations at a TSD facility. The code was based on detailed assessments of potential radiological exposures and doses at eight commercial hazardous waste TSD facilities. The code was developed to provide both DOE and commercial TSD facilities with a rapid and costeffective method for assessing potential human radiological impacts from processing (at commercial facilities) chemical wastes contaminated with trace amounts of radionuclides.

In December 1997, DOE initiated revisions to the TSD-DOSE code to incorporate comments received from users and to add new features. Improvements were made to increase the capability, accuracy, and flexibility of TSD-DOSE. This manual describes these enhancements. Updates to Version 2.0 and above include the following:

- Inclusion of RESRAD External Model: For analysis of the worker dose, the new version of TSD-DOSE incorporates the external gamma dose model used in the existing residual radioactive (RESRAD) material guidelines code (Yu et al. 1993). The RESRAD external exposure model is based on the U.S. Environmental Protection Agency's (EPA's) Federal Guidance Report No. 12 (FGR-12) (Eckerman and Ryman 1993), in combination with the Monte Carlo N-Particle (MCNP) transport code (Briesmeister 1993). This external dose model incorporates external dose conversion factors from FGR-12 and allows the user to vary the source dimensions and the shielding thickness. RESRAD is the computer code used in implementing DOE's residual radioactive material guidelines.

- Inclusion of 85 Radionuclides: One of the most substantial improvements to TSD-DOSE has been the expansion of the source term to a total of 85 radionuclides. Decay product radionuclides that have half-lives of less than 30 days are also included to maintain consistency with RESRAD. Expanding the source term to 85 radionuclides also maintains consistency with PNL-9405 (Aaberg et al. 1995), for which an extensive study was conducted of the radionuclides present in waste streams of various DOE facilities.

\footnotetext{
${ }^{1}$ References cited in this Preface are included in the reference list for the main text (Chapter 6).
} 
- Verification and Benchmarking of TSD-DOSE Model: TSD-DOSE has been validated against spreadsheet calculations to ensure that the worker doses are being computed correctly. The external model has been benchmarked against MCNP to ensure proper code execution for similarly shaped sources having similar material types. In addition, the off-site models have been benchmarked against the CAP88-PC computer code (EPA 1992). These verifications are documented in Chapter 5 of this manual.

- Other Modifications: Radionuclide-specific release fractions have been added to TSD-DOSE Version 2.0 and above. The user may accept the default release fractions or may enter site-specific information (if available) into TSDDOSE. Also, radionuclide food transfer factors have been updated for each new radionuclide added to TSD-DOSE. The food transfer factors are derived from vegetable/soil transfer factors and meat and milk transfer factors obtained from the RESRAD code and documented in Wang et al. (1993). 


\section{CONTENTS}

PREFACE .

iii

ACKNOWLEDGMENTS

NOTATION

ABSTRACT

1 INTRODUCTION

1.1 Objective

1

1.2 Background .................................................................................................. 2

1.3 Applicability ........................................................................................................ 3

1.4 Scope and Organization ................................................................................... 3

2 OVERVIEW OF THE MODEL ................................................................................... 5

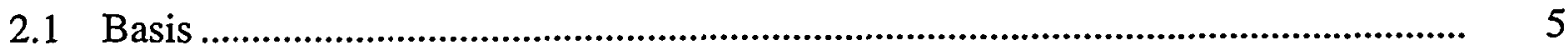

2.2 Methodology ................................................................................................................. 6

2.3 Reference Operations ..................................................................................................... 6

2.3.1 Operation 1 - Transport to a TSD Facility ...................................................... 7

2.3.2 Operation 2 - Receiving and Sampling.......................................................... 7

2.3.3 Operation 3 - Storage.............................................................................. 8

2.3.4 Operation 4 - Incineration.............................................................................. 8

2.3.5 Operation 5 - On-Site Landfill....................................................................... 9

2.3.6 Operation 6 - Transport to Off-Site Landfill .................................................... 9

2.3.7 Operation 7 - Incinerator Maintenance .......................................................... 10

2.4 Receptors.............................................................................................................. 10

2.5 Isotope Selection ............................................................................................ 10

$3 \quad$ ANALYSIS OF WORKER DOSES .................................................................................... 12

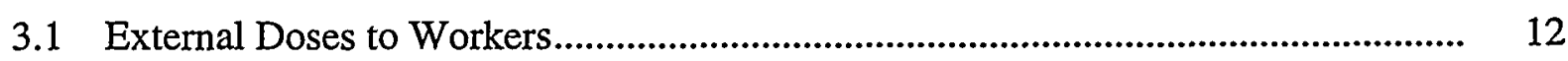

3.1.1 Operations 1,2 , and 3............................................................................... 17

3.1.2 Operations 4, 5, and 6........................................................................ 18

3.1.3 Operation 7 …............................................................................................ 19

3.2 Internal Doses to Workers.................................................................................... 20

3.2.1 Operation 2C - Inspect and Sample the Drums ........................................... 21

3.2.2 Operation 4 - Incineration....................................................................... 23

3.2.3 Operation 5 - Landfill Operations......................................................... 24

3.2.4 Operation 7 - Maintenance of the Incinerator System ................................. 25 


\section{CONTENTS (Cont.)}

4 ANALYSIS OF THE OFF-SITE PUBLIC DOSE ............................................................. 26

4.1 Normal Stack Release .............................................................................................. 26

4.1.1 Model for Doses to an Individual.................................................................... 27

4.1.2 Model for Doses to the General Population .................................................... 30

4.2 Landfill Operations........................................................................................................ 32

5 VERIFICATION AND BENCHMARKING OF TSD-DOSE MODEL ........................... 33

5.1 Verification and Benchmarking of Worker Doses .......................................................... 33

5.1.1 Verification of Internal Doses to Workers ...................................................... 33

5.1.2 Benchmarking of External Doses to Workers ................................................... 38

5.2 Verification and Benchmarking of Off-Site Public Dose............................................ 38

5.2.1 Verification of Effective Dose Conversion Factors ....................................... 38

5.2.2 Verification of Off-Site Individual Model ..................................................... 41

5.2.3 Verification of Off-Site Population Model .................................................. 41

5.2.4 Benchmarking of Off-Site Public Doses ........................................................... 41

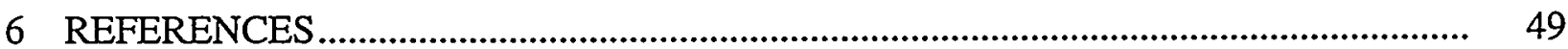

APPENDIX A: Program Instructions ……...................................................................... A-1

APPENDIX B： Worker Dose Parameter Values ……….............................................................. B-1

APPENDIX C: Glossary ............................................................................................ C-1

\section{FIGURES}

1 Exposure Geometry Considered for Area Factor Calculation........................................... 15

2 Cross Section of Exposure Geometry Showing Element of Integration for Area Factor Calculation......................................................................................................

3 Verification of Internal Doses to Workers from Sampling and Inspection, Normal Stack Release, Landfill, and Incinerator Maintenance

Operations for Radium-226.

$4 \quad$ Verification of the Effective Dose Conversion Factor for Cobalt-60 …........................... 39

$5 \quad$ Verification of the Effective Dose Conversion Factor for U-238+D ............................... 39 


\section{FIGURES (Cont.)}

6 Verification of the Off-Site Individual Dose from Incineration Operations for Cobalt-60

$7 \quad$ Verification of the Off-Site Individual Dose from Landfill Operations for Cobalt-60

8 Verification of the Off-Site Population Dose from Incineration Operations for Cobalt-60..

9 Verification of the Off-Site Population Dose from Landfill Operations for Cobalt-60

10 Correlation of Off-Site Individual Dose Calculations: TSD-DOSE versus CAP88-PC

11 Correlation of Off-Site Population Dose Calculations: TSD-DOSE versus CAP88-PC

12 CAP88-PC versus TSD-DOSE Individual Dose Benchmarking for All Radionuclides Based on a 1-Ci Release

13 CAP88-PC versus TSD-DOSE Population Dose Benchmarking for All Radionuclides Based on a 1-Ci Release.

A.1 Main Screen of TSD-DOSE

A.2 Program Map of the GUI.

A.3 Adjustable Parameters Screen for Transport to TSD Facility

A.4 The Menu Bar

A.5 Flowchart for GUI Usage

A-10

\section{TABLES}

$1 \quad$ Isotopes Used in the Dose Assessment Model................................................................... 4

2 Relationship between Receptors and TSD Operations ..................................................... 11

3 Parameters Used in Evaluating Internal Dose to Workers

from Sampling and Inspection Operations. 


\section{TABLES (Cont.)}

$4 \quad$ Parameters Used in Evaluating Internal Dose to Workers

from Normal Stack Release

5 Parameters Used in Evaluating Internal Dose to Workers

from Landfill Operations.

6 Parameters Used in Evaluating Internal Dose to Workers

from Incinerator Maintenance

36

7 Comparison of Internal TSD-DOSE Model Predictions with Spreadsheet

Calculations for the Worker from Sampling and Inspection, Normal Stack

Release, Landfill, and Incinerator Maintenance Operations

8 General Parameters and Values Used for the Off-Site Exposure Models in TSD-DOSE

9 Comparison of TSD-DOSE Model Predictions with CAP88-PC Calculations

for the Individual and General Population for Stack Releases

from Incineration and for Landfill Operations

B.1 Parameter Ranges Based on Eight Previously Assessed TSD Facilities

B-4

B.2 External Dose Default Parameter Values.

B-5

B.3 Internal Dose Default Parameter Values

B-6 


\section{ACKNOWLEDGMENTS}

The authors wish to express their thanks to the U.S. Department of Energy (DOE), Office of Environmental Management (EM), for funding this project. Also, we want to thank C. Ma, T. Wheeler, and M. Shannon, affiliated with M.H. Chew \& Associates, Inc., Livermore, California, for their contribution to the analysis of worker doses.

Leadership for this project has been provided by the DOE program manager, Hank Himpler, and the former program manager, Lee Stevens. Appreciation is also extended to Bruce Burnett of BDM and Kirk Owens of Science Applications International Corporation for their assistance. We also thank Gustavo Vazquez and Andrew Wallo of DOE, Office of Environmental Policy and Assistance, and Fred Monette and Sunita Kamboj of Argonne National Laboratory for their critical reviews and substantive recommendations in preparation of this document. 


\section{NOTATION}

The following is a list of the acronyms, initialisms, and abbreviations (including elements and units of measure) used in this document. Acronyms and abbreviations used only in tables and equations are defined in the respective tables and equations.

\section{ACRONYMS, INITIALISMS, AND ABBREVIATIIONS}

$\begin{array}{ll}\text { Aptus } & \text { Aptus Environmental Services, Inc. } \\ \text { CFR } & \text { Code of Federal Regulations } \\ \text { CWM } & \text { Chemical Waste Management, Inc. } \\ \text { DOE } & \text { U.S. Department of Energy } \\ \text { ENSCO } & \text { Environmental Systems Company, Inc. } \\ \text { EPA } & \text { U.S. Environmental Protection Agency } \\ \text { FGR } & \text { Federal Guidance Report } \\ \text { GUI } & \text { graphical user interface } \\ \text { ICRP } & \text { International Commission on Radiological Protection } \\ \text { LWD } & \text { LWD, Inc. } \\ \text { MCNP } & \text { Monte Carlo N-Particle code } \\ \text { NCRP } & \text { National Council on Radiation Protection and Measurements } \\ \text { PC } & \text { personal computer } \\ \text { RAM } & \text { random access memory } \\ \text { RES } & \text { Rollins Environmental Services, Inc. } \\ \text { RESRAD } & \text { residual radioactive material guidelines code } \\ \text { RPC } & \text { respirable particulate concentration } \\ \text { SDM } & \text { S.D. Myers, Inc. } \\ \text { TSD } & \text { treatment, storage, and disposal }\end{array}$

\section{ELEMENTS}

$\begin{array}{llllll}\mathrm{Ac} & \text { Actinium } & \mathrm{Cm} & \text { Curium } & \mathrm{Nb} & \text { Niobium } \\ \mathrm{Ag} & \text { Silver } & \mathrm{Co} & \text { Cobalt } & \mathrm{Ni} & \text { Nickel } \\ \mathrm{Al} & \text { Aluminum } & \mathrm{Cs} & \text { Cesium } & \mathrm{Np} & \text { Neptunium } \\ \mathrm{Am} & \text { Americium } & \mathrm{Eu} & \text { Europium } & \mathrm{Pa} & \text { Protactinium } \\ \mathrm{Au} & \text { Gold } & \mathrm{Fe} & \text { Iron } & \mathrm{Pb} & \text { Lead } \\ \mathrm{Bi} & \text { Bismuth } & \mathrm{Gd} & \text { Gadolinium } & \mathrm{Pm} & \text { Promethium } \\ \mathrm{C} & \text { Carbon } & \mathrm{Ge} & \text { Germanium } & \mathrm{Po} & \text { Polonium } \\ \mathrm{Ca} & \text { Calcium } & \mathrm{H} & \text { Hydrogen } & \mathrm{Pu} & \text { Plutonium } \\ \mathrm{Cd} & \text { Cadmium } & \mathrm{I} & \text { Iodine } & \mathrm{Ra} & \text { Radium } \\ \mathrm{Ce} & \text { Cerium } & \mathrm{K} & \text { Potassium } & \mathrm{Ru} & \text { Ruthenium } \\ \mathrm{Cf} & \text { Californium } & \mathrm{Mn} & \text { Manganese } & \mathrm{S} & \text { Sulfur } \\ \mathrm{Cl} & \text { Chlorine } & \mathrm{Na} & \text { Sodium } & \mathrm{Sb} & \text { Antimony }\end{array}$




\section{ELEMENTS (Cont.)}

$\begin{array}{llllll}\text { Sc } & \text { Scandium } & \text { Sr } & \text { Strontium } & \text { Th } & \text { Thorium } \\ \text { Se } & \text { Selenium } & \text { Ta } & \text { Tantalum } & \text { Tl } & \text { Thallium } \\ \text { Sm } & \text { Samarium } & \text { Tc } & \text { Technetium } & \text { U } & \text { Uranium } \\ \text { Sn } & \text { Tin } & \text { Te } & \text { Tellurium } & \text { Zr } & \text { Zirconium }\end{array}$

\section{UNITS OF MEASURE}

$\begin{array}{llll}{ }^{\circ} \mathrm{C} & \text { degree(s) Celsius } & \mathrm{m}^{2} & \text { square meter(s) } \\ { }^{\circ} \mathrm{F} & \text { degree(s) Fahrenheit } & \mathrm{m}^{3} & \text { cubic meter(s) } \\ \mathrm{Ci} & \text { curie(s) } & \mathrm{mg} & \text { milligram(s) } \\ \mathrm{cm} & \text { centimeter(s) } & \mathrm{mi} & \text { mile(s) } \\ \mathrm{cm}^{3} & \text { cubic centimeter(s) } & \mathrm{min} & \text { minute(s) } \\ \mathrm{ft} & \text { foot (feet) } & \mathrm{mm} & \text { millimeter(s) } \\ \mathrm{ft}^{3} & \text { cubic foot (feet) } & \mathrm{mph} & \text { mile(s) per hour } \\ \mathrm{g} & \text { gram(s) } & \mathrm{mrem} & \text { millirem } \\ \mathrm{gal} & \text { gallon(s) } & \mathrm{pCi} & \text { picocurie(s) } \\ \mathrm{h} & \text { hour(s) } & \mathrm{s} & \text { second(s) } \\ \mathrm{in} . & \text { inch(es) } & \mathrm{yr} & \text { year(s) } \\ \mathrm{lb} & \text { pound(s) } & \mu \mathrm{m} & \text { micrometer(s) } \\ \mathrm{m} & \text { meter(s) } & & \end{array}$




\title{
TSD-DOSE: A RADIOLOGICAL DOSE ASSESSMENT MODEL FOR TREATMENT, STORAGE, AND DISPOSAL FACILITIES
}

by

M. Pfingston, J. Arnish, D. LePoire, and S.-Y. Chen

\begin{abstract}
Past practices at U.S. Department of Energy (DOE) field facilities resulted in the presence of trace amounts of radioactive materials in some hazardous chemical wastes shipped from these facilities. In May 1991, the DOE Office of Waste Operations issued a nationwide moratorium on shipping all hazardous waste until procedures could be established to ensure that only nonradioactive hazardous waste would be shipped from DOE facilities to commercial treatment, storage, and disposal (TSD) facilities. To aid in assessing the potential impacts of shipments of mixed radioactive and chemically hazardous wastes, a radiological assessment computer model (or code) was developed on the basis of detailed assessments of potential radiological exposures and doses for eight commercial hazardous waste TSD facilities. The model, called TSD-DOSE, is designed to incorporate waste-specific and site-specific data to estimate potential radiological doses to on-site workers and the off-site public from waste-handling operations at a TSD facility. The code is intended to provide both DOE and commercial TSD facilities with a rapid and cost-effective method for assessing potential human radiation exposures from the processing of chemical wastes contaminated with trace amounts of radionuclides.
\end{abstract}

\section{INTRODUCTION}

\subsection{OBJECTIVE}

The dose assessment model TSD-DOSE provides the U.S. Department of Energy (DOE) with a simple, easy-to-use tool for estimating radiological doses to workers and the surrounding public at a commercial treatment, storage, and disposal (TSD) facility for hazardous waste as a result of processing waste slightly contaminated with radionuclides. The dose assessment model has been developed as part of a larger effort to dispose of hazardous waste potentially contaminated with radionuclides and currently stored at several DOE sites. The model provides information that may be used by DOE, regulators, facility operators, and others in their approval decision-making process. The intent of this document is to provide the user with a basic 
understanding of the development and technical background of the model, as well as instructions for operating the computer program.

\subsection{BACKGROUND}

In May 1991, DOE Headquarters learned that past practices at DOE field facilities resulted in the presence of minute amounts of radioactive contamination in some hazardous wastes. These hazardous wastes had been shipped to various commercial TSD facilities not licensed to receive radioactive materials. As a result of these shipments, DOE Headquarters mandated a moratorium that stopped off-site shipment from DOE facilities of hazardous wastes until procedures could be established to ensure that only nonradioactive hazardous waste would be shipped.

To determine the radiation exposures for commercial hazardous waste workers and the off-site public resulting from previous contaminated shipments, detailed radiological dose assessments were performed for the following eight TSD facilities:

- Aptus Environmental Services, Inc. (Aptus), Coffeyville, Kansas (Aptus 1992);

- Chemical Waste Management, Inc. (CWM), Chicago, nlinois (CWM 1994);

- Chemical Waste Management, Inc., Emelle, Alabama (CWM 1993a);

- Chemical Waste Management, Inc., Lake Charles, Louisiana (CWM 1993b);

- Environmental Systems Company, Inc. (ENSCO), El Dorado, Arkansas (ENSCO 1993);

- LWD, Inc. (LWD), Calvert City, Kentucky (LWD 1993);

- Rollins Environmental Services, Inc. (RES), Deer Park, Texas (RES 1994); and

- S.D. Myers, Inc. (SDM), Tallmadge, Ohio (SDM 1993).

Doses at these eight facilities were assessed on an annual basis rather than shipment by shipment. Worker doses ranged from $2 \times 10^{-6}$ mrem to $7 \times 10^{-2}$ mrem annually. Annual doses to the maximally exposed off-site individual were between $1 \times 10^{-7} \mathrm{mrem}$ and $1 \times 10^{-3} \mathrm{mrem}$. Off-site population doses were between $4 \times 10^{-7}$ person-rem and $3 \times 10^{-1}$ person-rem. These 
doses are extremely small and are well within the regulatory limits. Typical individual background radiation doses from terrestrial and cosmic sources range from 50 mrem to 200 mrem annually (NCRP 1987). The dose assessments for these eight facilities indicated that it is highly unlikely that the previous shipments resulted in health impacts to the workers or the public. The issues related to the radiological dose assessment for the TSD facilities were summarized by Stevens et al. (1995a).

Because the detailed assessments indicated extremely small doses, the benefits of conducting additional dose assessments using this level of detail could not justify the resources required to perform them. The TSD-DOSE dose assessment model was originally developed as a cost-effective alternative to performing additional detailed dose assessments of shipments made prior to the shipping moratorium. The experience and insight gained from the detailed studies of the eight TSD facilities became the bases for TSD-DOSE model development.

Earlier versions of the model (Stevens et al. 1995b) were spreadsheets that required an intricate understanding of the model. Therefore, to make the model easy to understand and to apply to future shipments, a Windows ${ }^{\circledR}$-based, point-and-click graphical user interface (GUI) was created. The approach has been summarized by Stevens et al. (1996) and by Chen et al. (1996).

\subsection{APPLICABILITY}

The TSD-DOSE assessment model can be applied in situations that meet both of the following criteria:

- The TSD facility being evaluated processes waste in a manner that can be modeled by using the reference operations described in Section 2.3.

- The shipment being assessed contains one or more of the radionuclides listed in Table 1 (and insignificant amounts of any others).

The purpose of the model is to enable TSD facilities, site managers, and others to calculate possible radiological doses from processing DOE waste shipments and to assess the risks involved. The model can also be used by DOE personnel to screen possible shipments.

\subsection{SCOPE AND ORGANIZATION}

The purpose of this document is to explain the technical basis of the dose assessment model TSD-DOSE and to provide instructions on using the GUI. This document is organized 
TABLE 1 Isotopes Used in the Dose Assessment Model

\begin{tabular}{llll}
\hline & & & \\
Ac-227+D & Cs-134 & Np-237+D & Sr-85 \\
Ag-108+D & Cs-135 & Pa-231 & Sr-89 \\
Ag-110m+D & Cs-137+D & Pb-210+D & Sr-90+D \\
A-126 & Eu-152 & Pm-147 & Ta-182 \\
Am-241 & Eu-154 & Po-210 & Tc-99 \\
Am-243+D & Eu-155 & Pu-238 & Te-125m \\
Au-195 & Fe-55 & Pu-239 & Th-228+D \\
Bi-207 & Fe-59 & Pu-240 & Th-229+D \\
C-14 & Gd-152 & Pu-241+D & Th-230 \\
Ca-41 & Gd-153 & Pu-242 & Th-232 \\
Ca-45 & Ge-68+D & Pu-244+D & Tl-204 \\
Cd-109 & H-3 & Ra-226+D & U-232 \\
Ce-141 & $\mathrm{I}-125$ & Ra-228+D & U-233 \\
Ce-144+D & I-129 & Ru-106+D & U-234 \\
Cf-252 & Ir-192 & S-35 & U-235+D \\
Cl-36 & K-40 & Sb-124 & U-236 \\
Cm-242 & Mn-54 & Sb-125+D & U-238+D \\
Cm-243 & Na-22 & Sc-46 & Zn-65 \\
Cm-244 & Nb-94 & Se-75 & Zr-95+D \\
Cm-248 & Nb-95 & Sm-147 & \\
Co-57 & Ni-59 & Sm-151 & \\
Co-60 & Ni-63 & Sn-113+D & \\
\hline
\end{tabular}

a The $+D$ notation refers to radionuclide progeny that have half-lives of less than 30 days. The radionuclide progeny are assumed to be in secular equilibrium with the parent radionuclide.

into six chapters (including this Introduction) and three appendixes. Chapter 2 presents an overview of the approach used to develop the model and also establishes the major operations and the operational steps used to model a TSD facility. Chapter 3 presents the derivation of the formulas used to calculate external and internal doses for workers. Chapter 4 contains the formulas for off-site doses to the general public. Information on verification and benchmarking for the worker and the off-site public exposure models incorporated into TSD-DOSE is presented in Chapter 5. Chapter 6 provides citations for the references cited in the document. Appendix A presents instructions for operating the GUI. Appendix B gives the data used in worker dose calculations. Appendix $C$ is a glossary of terms. 


\section{OVERVIEW OF THE MODEL}

This chapter describes the basis for the TSD-DOSE dose assessment model, presents the methodology used to develop it, and provides a general overview of the model and of the generalized TSD facility operations on which it is based. This chapter provides information needed to understand the basic principles of the model without including the detailed equations and derivations used for the calculations. The detailed technical information and appropriate equations are presented in Chapters 3 and 4.

\subsection{BASIS}

The TSD-DOSE model is based on information acquired and results obtained from indepth radiological dose assessments performed for eight TSD facilities that received slightly contaminated DOE waste prior to the 1991 shipping moratorium (Aptus 1992; CWM 1993a-b, 1994; ENSCO 1993; LWD 1993; SDM 1993; RES 1994). Two main conclusions from the eight detailed assessments that led to the development of the model are as follows:

- Waste handling and treatment operations for various TSD facilities are similar. For example, incinerators of different designs follow similar operational steps as far as radiation exposure is concerned. This similarity allowed generalized operations and operational steps to be developed for the model.

- The radioactivity levels in the shipments and the resulting doses were extremely small and had no discernible health impacts on the workers or the public. This conclusion allowed the use of conservative modeling generalizations and simplifications that still resulted in small calculated doses.

These two conclusions suggest that for slightly contaminated wastes, consideration of detailed variations of operations is not important for dose calculations. If details of TSD facility activities were generalized by using conservative assumptions and if minor details were omitted, the resultant calculated doses would remain extremely low. Therefore, for dose calculations involving slightly contaminated waste, operations of the same type can be approximated by reference operations that encompass the major activities. The concept of reference operations is the basis of this dose assessment model. 


\subsection{METHODOLOGY}

The TSD-DOSE model was developed in four basic steps:

- Development of Reference Operations. Seven reference operations that might contribute to radiation exposures for TSD facility workers and the public were developed on the basis of information gathered from the eight previously analyzed TSD facilities. Each operation was subdivided into a series of steps. Key parameters and ranges of their values were chosen on the basis of observations made during walk-throughs of the eight TSD facilities. Each reference operation is treated as an individual module. Facilities are modeled by combining the applicable reference operations or modules.

- Selection of Isotopes. Eighty-five isotopes were selected for dose calculations in the model on the basis of a survey of the characteristics of DOE low-level waste streams and the previous TSD facility dose assessments.

- Development of Dose Calculations. Mathematical models were developed to calculate doses to on-site workers and the off-site public for each reference operation. Through use of conservative parameter values derived from the eight TSD facilities, bounding dose calculations were performed on the basis of unit activity. Methods were then developed, where necessary, to adjust the bounding doses to achieve more accurate values by using actual facility parameters. The calculations are discussed in detail in Chapters 3 and 4.

- Development of a Graphical User Interface. TSD-DOSE is a PC-based program that runs on any IBM-compatible computer (80386 or higher). The model uses a simple point-and-click means of constructing cases. Default values are provided for most input parameters, although site-specific values can be used if data are available. The model contains detailed help screens to aid the user. The model is run by (1) choosing one or more reference operations to describe waste processing at the facility of interest, (2) defining the source term by choosing from the list of 85 radionuclides and entering the activity levels, and (3) choosing the receptors of interest. The code output includes a list of all input parameters and detailed assessment results. Detailed system requirements and a description of the GUI are provided in Appendix A.

\subsection{REFERENCE OPERATIONS}

The seven reference operations developed on the basis of the eight previously analyzed TSD facilities are described in the following subsections. Each operation consists of several 
operational steps, which are briefly described. The majority of these operations result in only external radiation exposure to TSD facility workers, but public doses or internal worker doses are also noted where applicable.

\subsubsection{Operation 1 - Transport to a TSD Facility}

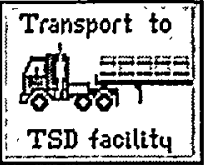

For transport of waste to a TSD facility, the transport vehicle is modeled as a flatbed truck carrying 40 drums. The operation consists of four steps:

A. Load and Secure Shipment. This step involves loading and securing the drums onto a flatbed truck for transport to a TSD facility.

B. Drive. This step involves driving the loaded truck to a TSD facility.

C. Rest. This step refers to rest breaks that the driver takes in the back of the cab of the flatbed truck en route to a TSD facility.

D. Perform en Route Maintenance. This step involves truck maintenance activities en route to the TSD facility, such as checking tires or refueling.

\subsubsection{Operation 2-Receiving and Sampling}

Receiving

마 II

and Sampling
The receiving and sampling operation involves the activities associated with receiving the waste at the TSD facility, including weighing the vehicle; checking the manifest; and unloading, sampling, and transporting the waste to the storage area. The activities are modeled in five steps:

A. Weigh Truck, Inspect Manifest. This step includes all check-in activities prior to unloading the waste.

B. Unload Drums. This step includes unloading the drums from the truck and moving them to the sampling area with either a forklift or hand truck.

C. Inspect and Sample the Drums. This step involves a worker standing next to an open drum to sample the waste. The assumption is made that the worker incurs an internal dose from this operation because of inhalation of vapors or dust from the open waste drum. 
D. Transfer Solids to Storage. This step involves transporting drums containing solid waste to a storage area before incineration or burial.

E. Pump Drummed Liquids to Storage Tank. This step involves a worker standing next to the drum while liquids are pumped into a large tank in a storage area.

\subsubsection{Operation 3-Storage}

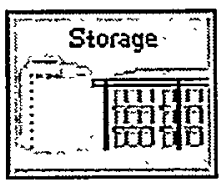

The storage operation involves storing the waste prior to incineration or burial. The operation consists of three steps:

A. Work in Solid Waste Storage Area. This step models a worker's exposure to drummed solid waste while working in the storage area. Doses depend on the amount of time workers spend in the vicinity of the waste.

B. Transfer Solids. This step involves transferring the drummed solid waste to an incinerator or landfill.

C. Work in Liquid Waste Storage Area. This step models a worker's exposure in the liquid waste storage tank area. Doses depend on the amount of time workers spend in the vicinity of the waste.

\subsubsection{Operation 4 - Incineration}

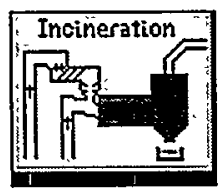

The incineration operation models the incineration of waste and the removal of ash and loose plateout, but it does not include removal of plateout from the kiln walls, which is modeled in the incinerator maintenance operation. Incineration consists of four steps:

A. Incinerate Waste. No external dose results from incineration of the waste because all workers are assumed to be a significant distance from the kiln. Incinerator stack release is the primary contributor to off-site public doses. On-site workers can be affected by incinerator emissions under fumigation or building-wake conditions (or both).

B. Collect Residue in Bin. This step involves placing residues from the filters and scrubbers and those from maintenance activities in a rectangular bin. 
C. Transport Bin to Storage Area. This step involves transporting the residues in the rectangular bin to the storage area.

D. Transport Bin from Storage Area. This step involves transporting the residues in the bin from the storage area to a mixing pit in preparation for on-site burial or to a dump truck for transport off-site.

\subsubsection{Operation 5 - On-Site Landfill}

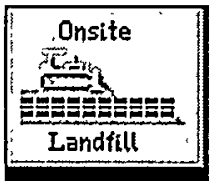

The on-site landfill operation includes the activities leading to burial of the waste or residues from incineration in an on-site landfill. The actual burial of the waste at the landfill is not included because of the amount of shielding (i.e., bulldozer and 8 in. of soil) between the worker and the source. This operation consists of four steps:

A. Unload Waste to Mixing Pit. This step models the unloading of the waste from a dump truck to a mixing pit. This step could also result in an internal dose to landfill workers because of the dust generated when the waste is dumped.

B. Mix Waste in Mixing Pit. This step involves mixing and stabilizing the waste in a below-grade mixing pit before burial in a landfill.

C. Load Truck and Transport Waste to Landfill. This step models loading the stabilized waste into a dump truck and transporting it to the on-site landfill.

D. Unload Truck at Landfill. This step models the unloading of the stabilized waste into the on-site landfill.

\subsubsection{Operation 6 - Transport to Off-Site Landfill}

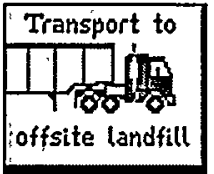

The transport to off-site landfill operation involves transporting the incineration residues to an off-site landfill for burial. The operation consists of four steps:
A. Load and Secure Waste. This step involves loading the residues from incineration onto a dump truck for transport to an off-site landfill.

B. Drive. This step involves driving the dump truck to the off-site landfill. 
C. Rest. This step refers to rest breaks that the driver takes en route from the TSD facility.

D. Perform en Route Maintenance. This step involves truck maintenance activities en route to the off-site landfill, such as checking tires or refueling.

\subsubsection{Operation 7 - Incinerator Maintenance}

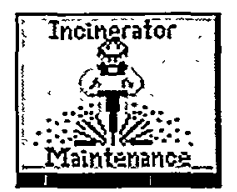

The incinerator maintenance operation involves removing plateout from the inside of the kiln and consists of only one step. The activities involved in this operation include using jackhammers to remove the plateout and bricks from the interior of the kiln and removing the debris. The assumption is made that the dust generated by the removal of the plateout results in an internal dose to incineration workers.

\subsection{RECEPTORS}

The TSD-DOSE model estimates doses to workers and the off-site public from treatment, storage, and disposal of waste contaminated with small quantities of radionuclides. The on-site TSD facility receptors include drivers, receiving workers, incinerator workers, landfill workers, and the collective worker population. Off-site receptors are analyzed for both individuals and populations living within 50 miles of the TSD facility. Table 2 shows which operations contribute to the dose for each receptor.

\subsection{ISOTOPE SELECTION}

The isotopes available in the dose assessment model are listed in Table 1. On the basis of previous TSD facility dose assessments; a survey of DOE waste streams; Code of Federal Regulations, Title 10, Part 61 (10 CFR61); and similar dose calculation codes, these isotopes were assumed to encompass the majority of the radionuclides present in DOE wastes. 
TABLE 2 Relationship between Receptors and TSD Operations ${ }^{a}$

\begin{tabular}{lcc}
\hline \multicolumn{1}{c}{ Receptor } & $\begin{array}{c}\text { Sources of } \\
\text { Internal Exposure }\end{array}$ & $\begin{array}{c}\text { Sources of } \\
\text { External Exposure }\end{array}$ \\
\hline Driver & $4(10 \%)^{\mathrm{b}}$ & 1,6 \\
Receiving worker & 2,4 & 2,3 \\
Incineration worker & 4,7 & $3,4,7$ \\
Landfill worker & 4,5 & 5 \\
Off-site individual & 4,5 & 4,5 \\
Off-site population & 4,5 & 4,5 \\
\hline
\end{tabular}

a Operations key: 1, transport to TSD facility; 2 , receiving and sampling; 3 , storage; 4 , incineration; 5 , on-site landfill; 6 , transport to off-site landfill; and 7, incinerator maintenance.

b The driver is assumed to be present at the site only $10 \%$ of the time. 


\section{ANALYSIS OF WORKER DOSES}

This chapter describes the methods used to calculate the individual doses to workers. Sections 3.1 and 3.2 discuss calculations of external and internal doses, respectively. In addition to calculating these individual doses, the TSD-DOSE model also calculates the collective dose to the worker population. The worker population dose (reported in person-rem) is estimated by multiplying the number of workers involved in an operation by the individual dose for that operation. The parameters used in the dose calculations for the TSD worker are provided in Appendix B. Chapter 4 describes the methods used to calculate off-site doses to the public.

\subsection{EXTERNAL DOSES TO WORKERS}

This section presents the formulas used to calculate the worker external doses associated with the reference operations. The external model in TSD-DOSE provides the unique feature of allowing users to choose geometry parameters on-line. This feature permits users to construct their tailored scenarios for volume-contaminated sources. External doses $\left(D^{\text {ext }}\right)$ for both solids and liquids are presented in terms of the effective dose equivalent:

$$
\begin{gathered}
D^{\text {ext }}=\sum \sum\left(D_{i, j}^{\text {ext, solid }}+D_{i, j}^{\text {extliquid }}\right) \\
D_{i, j}^{\text {ext, solid }}=D C F_{i, j}^{\text {ext }} A_{i} \cdot P_{j} \cdot T_{j} \cdot N_{j} \cdot F S W_{j} \cdot \frac{1}{M} \\
D_{i, j}^{\text {ext,liquid }}=D C F_{i, j}^{\text {ext }} A_{i} \cdot P_{j} \cdot T_{j} \cdot N_{j} \cdot\left(1-F S W_{j}\right) \cdot \frac{1}{M},
\end{gathered}
$$

where

$$
\begin{aligned}
D_{i, j}^{\text {ext, solid }}= & \begin{array}{l}
\text { external radiation dose for radionuclide } i \text { from operation } j \text { for solid waste } \\
(\text { mrem }) ;
\end{array} \\
D_{i, j}^{\text {ext liquid }}= & \text { external radiation dose for radionuclide } i \text { from operation } j \text { for liquid waste } \\
& (\text { mrem); } \\
& \\
D C F_{i, j}^{\text {ext }}= & \text { external dose conversion factor dependent on source geometry }(g), \text { source } \\
& \text { distance }(d), \text { source density }(\rho), \text { and source shielding (sh) } \\
& {[(\text { mrem } / \mathrm{h}) /(\mathrm{pCi} / \mathrm{g})] ; }
\end{aligned}
$$


$A_{i}=$ total activity of radionuclide $i$ in the waste stream (pCi);

$P_{j}=$ process factor, equal to processed waste-specific activity divided by unprocessed waste-specific activity (dimensionless);

$T_{j}=$ duration of the operation (h);

$N_{j}=$ number of times each operation is performed (dimensionless);

$F S W_{j}=$ fraction of solid waste for each operation (dimensionless); and

$$
M=\text { total mass of waste }(\mathrm{g}) .
$$

The subscript $i$ denotes the various isotopes, and the subscript $j$ denotes various operational steps. The external dose for each individual worker is summed across all isotopes and all operations applicable to that worker.

The external dose conversion factor depends on the geometry of the source relative to the point where the dose is to be evaluated. Each volume is modeled as a rectangular source. The geometry is specified by the length, height, and width of the source; the perpendicular distance between the source and receptor; and the shielding between the source and receptor. The external model in TSD-DOSE uses the latest U.S. Environmental Protection Agency (EPA) external dose conversion factors of Federal Guidance Report No. 12 (FGR-12) (Eckerman and Ryman 1993), which include dose contributions from both gamma and beta radiation. TSD-DOSE uses these dose conversion factors for rotational exposure as reference points. The methodology described by Kamboj (1998) for corrections due to the finite size was extended to include differences in source configuration. The external dose conversion factor is derived as follows:

$$
D C F_{i, j}^{e x t}=D_{\infty, i} \times F_{C D} \times F_{A, j}^{n u c} \times F_{s, j}
$$

where

$$
\begin{aligned}
D C F_{i, j}^{e x t}= & \begin{array}{l}
\text { external dose conversion factor for radionuclide } i[(\mathrm{mrem} / \mathrm{h}) /(\mathrm{pCi} / \mathrm{g})] \text { for } \\
\text { operation } j ;
\end{array} \\
D_{\infty, i}= & \begin{array}{l}
\text { FGR-12 dose conversion factor for semi-infinite volume-contaminated } \\
\text { source for radionuclide } i[(\mathrm{mrem} / \mathrm{h}) /(\mathrm{pCi} / \mathrm{g})] ;
\end{array} \\
F_{C D}= & \text { depth-and-cover factor (dimensionless); }
\end{aligned}
$$


$\begin{aligned} F_{A, j}^{n u c}= & \text { radionuclide-specific area factor for a circular area for operation } \mathrm{j} \\ & \text { (dimensionless) } ; \text { and }\end{aligned}$

$F_{s, j}=$ shape factor for operation $\mathrm{j}$ (dimensionless).

Dose conversion factors are given in FGR-12 for surface and uniformly distributed volume sources at four specific thicknesses $(1,5,15 \mathrm{~cm}$, and effectively infinite) with soil density of $1.6 \mathrm{~g} / \mathrm{cm}^{3}$. FGR-12 assumes that sources are infinite in lateral extent. In actual situations, sources can have any depth, shape, cover, and size. A depth-and-cover factor function, $F_{C D}$, was developed with regression analysis to express the attenuation for radionuclides. Three independent radionuclide-specific parameters were determined by using the effective dose equivalent values of FGR-12 at different depths. A depth-and-cover factor function was derived from the depth factor function by considering both dose contribution and attenuation from different depths:

$$
F_{C D}=\frac{D\left(T_{c}=t_{c}, T_{s}=t_{s}\right)}{D\left(T_{c}=0, T_{s}=\infty\right)}=A e^{-K_{A} \rho_{c} t_{c}}\left(1-e^{-K_{A} \rho_{s} t_{s}}\right)+B e^{-K_{B} \rho_{c} t_{c}}\left(1-e^{-K_{B} \rho_{s} t_{s}}\right)
$$

where

$$
\begin{aligned}
A, B & =\text { fit parameters (dimensionless), } \\
K_{A}, K_{B} & =\text { fit parameters }\left(\mathrm{cm}^{2} / \mathrm{g}\right) \\
t_{c} & =\text { cover thickness }(\mathrm{cm}) \\
\rho_{c} & =\text { cover density }\left(\mathrm{g} / \mathrm{cm}^{3}\right) \\
t_{s} & =\text { source depth }(\mathrm{cm}) \\
\rho_{s} & =\text { source density }\left(\mathrm{g} / \mathrm{cm}^{3}\right) \\
T_{c} & =\text { cover parameter }(\mathrm{m}), \text { and } \\
T_{s} & =\text { source depth parameter }(\mathrm{m})
\end{aligned}
$$

The energy-dependent area factor, $F_{A}(E i)$, is used to derive the radionuclide-specific area factor $F_{A j} n u c$. This factor considers point kernel dose integral, $D\left(R, t_{a}, t_{c}, t_{s}\right)$, over the source thickness $\left(t_{s}\right)$, radius $(R)$, distance from the receptor to the plane of the source and air interface $\left(t_{a}\right)$, and thickness of the shielding material $\left(t_{c}\right)$, for rotational (ROT) geometry depicted in 
Figure 1. The area factor is the ratio of the dose integrals for the geometry being considered and the infinite slab geometry:

$$
\mathrm{F}_{A, j}(\mathrm{Ei})=\frac{\mathrm{D}\left(\mathrm{R}=\mathrm{r}, \mathrm{T}_{\mathrm{a}}=1 \mathrm{~m}, \mathrm{~T}_{\mathrm{c}}=\mathrm{t}_{\mathrm{c}}, \mathrm{T}_{\mathrm{s}}=\mathrm{t}_{\mathrm{s}}\right)}{\mathrm{D}\left(\mathrm{R}=\infty, \mathrm{T}_{\mathrm{a}}=1 \mathrm{~m}, \mathrm{~T}_{\mathrm{c}}=\mathrm{t}_{\mathrm{c}}, \mathrm{T}_{\mathrm{s}}=\mathrm{t}_{\mathrm{s}}\right)},
$$

where the function $D$ is the dose evaluated by using the point kernel method (Figure 2):

$$
D\left(R, t_{a}, t_{c}, t_{s}\right)=K \int_{V_{s}} e^{-z} \frac{B(z)}{4 \pi l^{2}} d V
$$

where

$$
z=\frac{\mu_{a} t_{a}+\mu_{c} t_{c}+\mu_{s} t}{t_{a}+t_{c}+t} l
$$

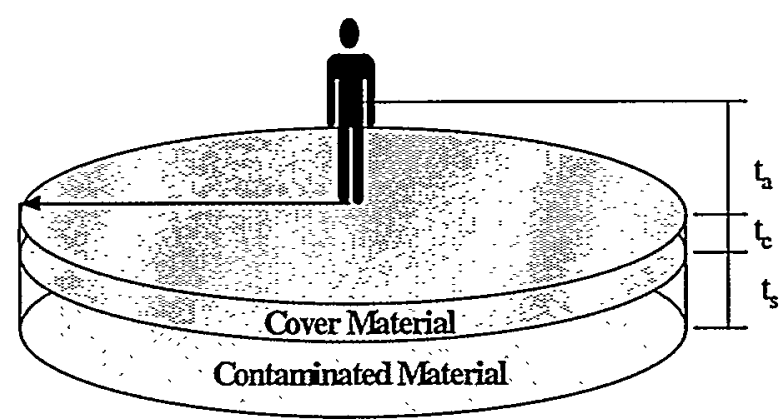

FIGURE 1 Exposure Geometry Considered for Area Factor Calculation

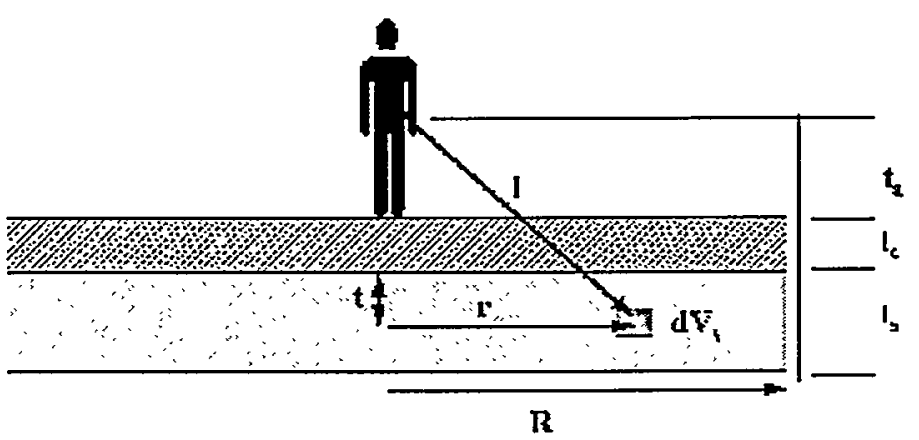

FIGURE 2 Cross Section of Exposure Geometry Showing Element of Integration for Area Factor Calculation 


$$
\begin{aligned}
l & =r^{2}+\left(t_{a}+t_{c}+t\right)^{2}, \\
d V_{s} & =2 \pi r t d r d t, \\
\mu_{a} & =\text { attenuation coefficient for air, } \\
\mu_{c} & =\text { attenuation coefficient for the cover material, } \\
\mu_{S} & =\text { attenuation coefficient of the source material, } \\
B(z) & =\text { buildup factor (G-P Method [Trubey 1991]) for length measured in mean } \\
K & =\text { free paths, } z, \text { and } \\
& \text { energy-dependent conversion factor. }
\end{aligned}
$$

The photon energies and yields of different radionuclides were obtained by condensing the International Commission on Radiological Protection (ICRP) Publication 38 (ICRP 1983) photon spectra. The algorithm used to condense the spectra consisted of taking the full spectra and repeatedly combining the photons that have the smallest relative ratio in their energies. The yield of the resultant photon is the sum of the yields of the two photons, and the energy is the yield-weighted energy of the two photons. This combining of pairs of photons was repeated until the closest pair had an energy ratio greater than 3. This process resulted in four or fewer collapsed photons for all radionuclides processed.

The radionuclide-specific area factor for a circular area, $F_{A, j}^{n u c}$, is obtained by combining the energy-dependent area factors weighted by their photon fraction, $F P T_{i}$, and dose contribution at the reference point:

$$
F_{A, j}^{n u c}=\frac{\sum_{i} F_{A j}\left(E P T_{i j}\right) F P T_{i} D_{s l a b}\left(E P T_{i}\right)}{\sum_{i} F P T_{i} D_{s l a b}\left(E P T_{i}\right)},
$$

where

$D_{s l a b}\left(E P T_{i}\right)=$ effective dose equivalent from the infinite slab geometry.

A shape factor, $F_{s, j}$, is used to correct a non-circular-shaped contaminated area on the basis of an ideally circular zone. The shape factor of a circular contaminated area is 1.0. For an irregularly shaped contaminated area, the shape factor is obtained by enclosing the irregularly 
shaped contaminated area in a circle, multiplying the area factor of each annulus by the fraction of the annulus area that is contaminated, summing the products, and dividing by the area factor of a circular contaminated zone that is equivalent in area:

$$
F_{s, j}=\frac{\sum_{i=0}^{n} f_{i}\left[F_{A}\left(A_{i}\right)-F_{A}\left(A_{i-1}\right)\right]}{F_{A}\left[\sum_{i=0}^{n} F_{i}\left(A_{i}-A_{i-1}\right)\right]}
$$

where

$f_{i}=$ fraction of annular area that is contaminated.

The general external dose equation (Equation 1) is applied to the seven specific reference operations (see Chapter 2) as described in the following sections.

\subsubsection{Operations 1,2 , and 3}

The process factor $(P)$ is unity because the DOE waste is not treated for operations 1,2 , and 3. The number of operations $(N)$ is obtained by dividing the mass of the DOE waste $(M)$ by the mass associated with the source geometry $\left(M_{g}\right)$. For operations 1 through 3 , the external worker dose is proportional to the activity.

\subsubsection{Operations 1, 2A, 2B, 2C}

For all of operation 1 and operations $2 \mathrm{~A}, 2 \mathrm{~B}$, and $2 \mathrm{C}$, the transportation and receiving workers are exposed to both solid and liquid waste; hence, the external radiation dose $\left(D^{\text {ext }}\right)$ in Equation 1 can now be expressed as:

$$
D_{i, j}^{\text {ext, solid +liquid }}=D C F_{i, j}^{e x t} \times \frac{A_{i}}{M} \times T_{j} \times \frac{M}{M_{g}}
$$




\subsubsection{Operations 2D, 3A, and 3B}

For operations $2 \mathrm{D}, 3 \mathrm{~A}$, and $3 \mathrm{~B}$, the receiving and sampling workers are exposed only to radiation from solid waste; therefore, the resulting dose from liquid waste would be zero. Hence Equation 1 can be expressed as:

$$
D_{i, j}^{\text {ext, solid }+ \text { liquid }}=D C F_{i, j}^{e x t} \times \frac{A_{i}}{M} \times T_{j} \times \frac{M}{M_{g}} \times F S W_{j}
$$

\subsubsection{Operations 2E and 3C}

For operations $2 \mathrm{E}$ and $3 \mathrm{C}$, the receiving and sampling workers are exposed only to radiation from liquid waste; therefore, the resulting dose from solid waste would be zero. Hence Equation 1 can be expressed as:

$$
D_{i, j}^{\text {ext solid }+ \text { liquid }}=D C F_{i, j}^{\text {ext }} \times \frac{A_{i}}{M} \times T_{j} \times \frac{M}{M_{g}} \times\left(1-F S W_{j}\right)
$$

\subsubsection{Operations 4,5 , and 6}

Operations 4,5 , and 6 involve residues from incineration. The conservative assumption is made that the incineration residues retain all of the activity of the original waste (except for volatile radionuclides such as tritium, which is assumed to be evaporated); thus, the process factor $(P)$ is expressed as:

$$
P=\frac{\sum A_{i} / M_{r e s}}{\sum A_{i} / M}=\frac{M}{M_{r e s}},
$$

where $M_{\text {res }}$ is the mass of the incineration residues.

The total number of bin, mixing pit, or dump truck loads needed to collect the potentially contaminated residues is expressed as $M_{\text {res }} M_{g}$. The expression for external radiation dose $\left(D_{\text {ext }}\right)$ can now be simplified as follows:

$$
D_{i, j}^{\text {ext, solid }+ \text { liguid }}=A_{i} \times D C F_{i, j}^{\text {ext }} \times T_{j} \times \frac{1}{M_{g}}
$$


Equation 11 shows that the external dose due to these operations is proportional to the total activity $(A)$ of all isotopes shipped.

\subsubsection{Operation 7}

The assumption is made that of the total waste incinerated annually by the TSD facility, $70 \%$ of the solid waste and $2 \%$ of the liquid waste remain as incineration residues. The specific activity of the plateout on the walls of the incinerator is the same as that of the residues. It is also assumed that the plateout is removed four times per year $(\mathrm{N})$. Therefore, the process factor is:

$$
\begin{gathered}
P=\frac{\frac{A_{i}}{\left[\left(0.7 \times M_{s o l}\right)+\left(0.02 \times M_{l i q}\right)\right]} \times N}{A_{i} / M_{p o}} \\
=\frac{M_{p o}}{\left[\left(0.7 \times M_{\text {sol }}\right)+\left(0.02 \times M_{\text {liq }}\right)\right]} \times N,
\end{gathered}
$$

where

$$
\begin{aligned}
P & =\text { process factor (dimensionless) } \\
M_{p o} & =\text { total annual mass of plateout }(\mathrm{g}) \\
M_{\text {sol }} & =\text { total annual mass of incinerated solid waste (g), and } \\
M_{l i q} & =\text { total annual mass of incinerated liquid waste (g), and } \\
N & =\text { number of times the plateout is removed per year (dimensionless). }
\end{aligned}
$$

By including the mass of the plateout, $M_{p o}$, the external radiation dose $\left(D^{e x t}\right)$ can be simplified as:

$$
D_{i, j}^{\text {ext solid }+ \text { liguid }}=A_{i} \times D C F_{i, j}^{e x t} \times T_{j} \times \frac{M_{p o}}{\left[\left(0.7 \times M_{\text {sol }}\right)+\left(0.02 \times M_{l i q}\right)\right]} \times N
$$

Equation 13 shows that the external dose to the incinerator maintenance workers is proportional to the total activity $(A)$ of all isotopes shipped to a TSD facility. 


\subsection{INTERNAL DOSES TO WORKERS}

The TSD workers may receive internal radiation exposure as a result of inhalation of airborne contamination caused by the handling and processing of DOE wastes. In this situation, radiation exposure as a result of ingestion has been found to contribute insignificantly to the worker internal dose. This section presents the formulas for calculating the worker internal doses associated with the reference operations. Internal doses are presented in terms of the committed effective dose equivalent.

The internal radiation dose $\left(D^{\text {int }}\right)$ caused by inhalation can be expressed in general as follows:

$$
\begin{gathered}
\mathrm{D}^{\mathrm{int}}=\sum \sum \mathrm{D}_{\mathrm{i}, \mathrm{j}}^{\mathrm{int}}, \\
D_{i, j}^{\mathrm{int}}=\frac{A_{i}}{M} \cdot R P C_{j} \cdot B R \cdot T_{j} \cdot N_{j} \cdot \frac{1}{P F_{j}} \cdot D C F_{i} \cdot F S W_{i} \cdot \frac{1}{D F_{j}},
\end{gathered}
$$

where

$$
\begin{aligned}
A_{i} & =\text { activity of radionuclide } i(\mathrm{pCi}), \\
M & =\text { total mass of waste }(\mathrm{mg}), \\
R P C_{j} & =\text { Respirable particulate concentration }\left(\mathrm{mg} / \mathrm{m}^{3}\right), \\
B R & =\text { breathing rate }\left(\mathrm{m}^{3} / \mathrm{s}\right), \\
T_{j} & =\text { exposure time for operation } \mathrm{j}(\mathrm{s}), \\
N_{j} & =\text { number of times each operation is performed (dimensionless), } \\
P F_{j} & =\text { respiratory protection factor (dimensionless), } \\
D C F_{i} & =\text { dose conversion factor (mrem } / \mathrm{pCi}), \\
F S W_{i} & =\text { fraction of solid waste (dimensionless), and } \\
D F_{j} & =\text { dilution factor (dimensionless). }
\end{aligned}
$$


The subscript $i$ denotes the various isotopes, and the subscript $j$ denotes the various operational steps. For each worker, the internal dose is summed across all isotopes and all applicable operations.

In the calculations described subsequently, the dose conversion factors are those given in Eckerman et al. (1988), and the breathing rate is taken to be the standard value of $11.7 \times 10^{-2} \mathrm{ft}^{3} / \mathrm{s}\left(3.33 \times 10^{-4} \mathrm{~m}^{3} / \mathrm{s}\right.$ ) (ICRP 1975). The selection of internal dose conversion factors for the listed isotopes accounts for the dose contribution of progeny radionuclides. The respiratory protection factors used for these calculations are listed in Appendix B. The following sections describe how the general formula, Equation 14, for inhalation dose is applied to the reference operations.

\subsubsection{Operation 2C - Inspect and Sample the Drums}

The model conservatively assumes that all drums are opened for inspection upon receipt and are sampled. Sampling methods vary, but this operation is modeled as a worker standing near an open drum, which accounts for the majority of possible sampling methods. The methods used for these calculations differ for tritium compared with the other radionuclides. Tritium is assumed to exist as water, and its release fraction is based on vapor pressure. The other radionuclides are assumed to be in solid form, and their release fraction is based on the airborne dust concentration.

\subsubsection{Particulate Release}

The conservative assumption is made that the waste is in solid form because liquids would offer no release mechanism for any radionuclide except tritium. The amount of activity released into the surrounding air when a drum containing solids is opened is estimated as follows:

- In drums containing solids, an air space (headspace) exists between the top surface of the drum's contents and the drumhead.

- Following tumbling of uranium oxide for 100 seconds, between $1.0 \mathrm{mg} / \mathrm{m}^{3}$ and $70 \mathrm{mg} / \mathrm{m}^{3}$ of airborne respirable particulates were detected in the interior of a ball mill (Schwendiman 1977). Because the DOE waste sampled would be dirt and debris and not the finely milled dust generated in the uranium oxide suspension studies, $10 \mathrm{mg} / \mathrm{m}^{3}$ is judged to be an appropriate, yet conservative, value for the respirable particulate concentration (RPC) generated during sampling in the drum headspace. The corresponding airborne activity concentration in the drum headspace is calculated by multiplying the respirable particulate concentration by the specific activity of the DOE waste. 
- Air currents and turbulence can result in some dilution of the contaminated air in the drum headspace with outside clean air after the drum is opened. A preliminary calculation yields an effective dilution factor $(D F)$ of about 30 .

- The number of operations $(N)$ is the total mass of the waste divided by the mass capacity of each drum $\left(M / M_{d r u m}\right)$.

Equation 14 can now be expressed as:

$$
D_{i, j}^{i n t}=A_{i} \cdot R P C_{j} \cdot \frac{1}{30} \cdot B R \cdot \frac{1}{P F_{j}} \cdot D C F_{i} \cdot F S W_{j} \cdot \frac{1}{D F_{j}} \cdot T_{j}
$$

\subsubsection{Tritium Release}

Some DOE waste may be contaminated with tritium, probably as water. The amount of radioactive tritium released into the surrounding air when a drum containing solid waste is opened is estimated as follows:

- The tritium is assumed to be in water that is associated with the solid waste. Because the amount of tritium is fixed, the assumption that a minimum amount of water is contained in the solid waste will maximize the specific activity of the tritiated water. In general, the content of unbound water in solids ranges from $0.5 \%$ to $5 \%$ (weight percent). The specific activity is inversely proportional to this weight percentage. Consequently, the value $1 \%$ by weight of water is conservatively employed in the model.

- The water vapor pressure in the drum headspace is conservatively assumed to be $50 \mathrm{~mm} \mathrm{Hg}$ (i.e., corresponding to water at a temperature of $100^{\circ} \mathrm{F}\left[38^{\circ} \mathrm{C}\right]$ ). The corresponding vapor density $(V D)$ in the headspace is $4.64 \times 10^{6} \mathrm{mg} / \mathrm{m}^{3}$.

- The tritium activity concentration in the drum headspace is calculated by multiplying the vapor density by the specific activity of tritium in the unbound water.

Equation 14 can now be expressed as:

$$
D_{3_{\mathrm{H}}}^{\text {int }}(\text { solid })=A_{3_{H}} \cdot V D \cdot \frac{1}{30} \cdot T_{j} \cdot \frac{B R}{P F} \cdot \frac{D C F_{3_{H}}}{M_{\text {drum }}} \cdot F S W_{j} .
$$


For all other radionuclides, there is no mechanism that would generate respirable airborne aerosols during inspection and sampling of liquid waste. Consequently, internal doses due to inspection and sampling of liquid waste are not calculated except when the liquid waste is contaminated with tritium. For such a case, the drum is assumed to have a water content of $10 \%$, and the tritium is assumed to be in the form of tritiated water. For liquid waste contaminated with tritium, the internal worker dose is estimated as:

$$
D_{3_{H}}^{\text {int }}(\text { liquid })=A \cdot 4.64 \times 10^{5} \mathrm{mg} / \mathrm{m}^{3} \cdot \frac{1}{30} \cdot T_{j} \cdot B R \frac{D C F_{3_{H}}}{M_{d r u m}} \cdot\left(1-F S W_{j}\right)
$$

\subsubsection{Operation 4 - Incineration}

This section describes the calculation of the internal dose to workers caused by the inhalation of radioactivity that could be released through the incinerator stack (Operation 4). The inhalation dose from the stack effluent when it reaches the receptor is calculated by:

$$
D_{i, j}^{i n t}=A_{i} \cdot R F \frac{\chi}{Q} \cdot B R \cdot D C F_{i}
$$

where

$$
\begin{aligned}
& \frac{\chi}{Q}=\text { atmospheric dispersion factor }\left(\mathrm{s} / \mathrm{m}^{3}\right) \text { and } \\
& R F=\text { release fraction (unitless). }
\end{aligned}
$$

The radionuclide-specific release fractions were obtained from Aaberg et al. (1995) and are listed in Table B.3 in Appendix B.

For elevated releases such as those from incinerator stacks, emissions generally would not reach ground level within the site boundary; however, two mechanisms - building wake and fumigation - may contribute to bring the stack effluent near ground level within the TSD facility site boundary.

When wind passes over a building, an area of low pressure is created along the back side. Air is pulled down to fill the gap. If the effective height of a stack is less than 2.5 times the height of surrounding structures, the building wake will entrain some of the stack effluent and bring it to the ground level on-site (DOE 1984). This building-wake effect can be accounted for by calculating the modified diffusion factors with the methodology outlined in the DOE publication Atmospheric Science and Power Production (DOE 1984). For a building $20 \mathrm{~m}$ high and $15 \mathrm{~m}$ 
wide, the resulting dispersion factor $(\chi / Q)$ was calculated to be $5 \times 10^{-5} \mathrm{~s} / \mathrm{m}^{3}$ at a receptor distance of $60 \mathrm{~m}$. The assumption was also made that the wind blows from the stack toward the buildings $50 \%$ of the time, resulting in the building-wake effect.

Fumigation conditions usually occur in the morning near sunrise. These conditions result when the stack plume does not penetrate the inversion boundary layer and is held near the stack release height, with vertical mixing taking place between the boundary layer and the ground. Because of solar heating, the inversion begins to dissipate and is replaced by a neutral or unstable layer that usually begins at ground level and works its way upward. This condition can result in a high contaminant concentration near ground level. Fumigation conditions can only exist under Class F diffusion conditions and are conservatively assumed to persist for about 30 minutes each time they occur (Slade 1968). On the basis of the meteorological data of the eight TSD facilities, the assumption is made that the fumigation condition exists about $1 \%$ of the total working time of a day-shift operator. Under fumigation conditions, the dispersion factor $\chi / Q$ was calculated to be $1 \times 10^{-4} \mathrm{~s} / \mathrm{m}^{3}$ (Westinghouse Idaho Nuclear Company, Inc. 1990).

The annual internal doses to the reference TSD facility on-site workers due to the stack releases are calculated according to Equation 17 by summing the fumigation and building-wake doses.

\subsubsection{Operation 5-Landfill Operations}

During the landfill operation, the unloading of soil or incineration residues from trucks may generate a small amount of respirable airborne particulates. Materials may also become airborne as a result of the mixing, leveling, and rolling of the waste deposited in the landfill; however, the truck driver and the operators generally remain in temperature-controlled, enclosed cabs during these operations. The travel surface within the landfill is often wetted to minimize generation of airborne dust. Inhalation doses from landfill operations were determined on the basis of the following assumptions:

- The airborne respirable particulate concentration $(R P C)$ at the disposal site is taken to be $1 \mathrm{mg} / \mathrm{m}^{3}$ (by comparison, the particulate concentration for clean air is about $0.01 \mathrm{mg} / \mathrm{m}^{3}$ ). The dust released during dumping would be dispersed by air movement; however, for conservatism, no air dilution factor is employed. Thus the airborne activity concentration is calculated by multiplying the $R P C$ by the specific activity of the DOE waste.

- The number of landfill operations $(N)$ is obtained by dividing the mass of the landfill waste $(M)$ by the mass of a truck load $\left(M_{\text {load }}\right)$. 
Thus one obtains:

$$
D_{i, j}^{i n t}=A_{i} \cdot R P C \cdot B R \cdot T_{j} \cdot \frac{1}{M_{\text {load }}} \cdot \frac{1}{P F_{j}} \cdot D C F_{i}
$$

\subsubsection{Operation 7 - Maintenance of the Incinerator System}

Workers performing incinerator maintenance may be required to use a jackhammer to dislodge vitrified material (plateout) accumulated on the incinerator walls. The method used to calculate the internal dose to the workers caused by the inhalation of respirable particulates generated during the removal of the plateout is discussed here.

From uranium oxide suspension studies, conservative judgment indicated that the respirable airborne particulate concentration generated in dislodging the vitrified material on the incinerator walls was $10 \mathrm{mg} / \mathrm{m}^{3}$. The corresponding airborne activity concentration is calculated by multiplying the respirable particulate concentration by the specific activity of the plateout and the process factor (see Equation 12).

Tritium is not considered in the maintenance dose calculation because free water and any tritium it contains are released during incineration. The internal doses to the workers performing maintenance inside the incinerator are estimated with Equation 19:

$$
\begin{aligned}
D_{i, j}^{i n t}= & \frac{A_{i}}{M_{P O}} \times \mathrm{RPC}_{i} \times \frac{M_{P O}}{\left[\left(0.7 \times M_{\text {sol }}\right)+\left(0.02 \times M_{\text {liq }}\right)\right]} \\
& \times \mathrm{N} \times \mathrm{BR} \times \mathrm{T}_{\mathrm{j}} \times \frac{1}{\mathrm{PF}_{\mathrm{j}}} \times \mathrm{DCF}_{1} .
\end{aligned}
$$




\section{ANALYSIS OF THE OFF-SITE PUBLIC DOSE}

The radiological dose to the off-site public depends in general on detailed site-specific data, such as meteorological, agricultural, population distribution, and stack-exhaust system design data. A simplified reference model for calculating the off-site public dose has been developed to provide a rapid, yet realistic, dose estimate for a TSD facility on the basis of knowledge of the general process steps at a facility and characteristics of the DOE waste shipments (i.e., in the absence of detailed site-specific information). The model was developed on the basis of detailed calculations performed for six of the eight TSD facilities studied for which an off-site public dose occurred. Five of these six TSD facilities were stack release facilities, and one was a landfill disposal facility. The TSD facilities studied fall into two general categories: those that have incinerators and those that have landfill disposal facilities. At incineration facilities, two types of releases to the atmosphere contribute to the off-site public dose: (1) normal stack releases and (2) emergency vent releases. Previous studies of the TSD facilities indicate that off-site doses are dominated by normal stack releases (more than $99 \%$ of the total dose estimated). Therefore, in TSD-DOSE, separate modeling of doses from emergency venting was not conducted, and all releases were assumed to be from the stack.

The dose models applicable to incineration facilities and to landfill operations are discussed in Sections 4.1 and 4.2, respectively. The site parameters that affect the off-site public doses have been screened, and equations have been developed that use a few key site-specific parameters to estimate the individual and population doses for members of the public around a TSD facility. The main input needed for the model is the activity of radionuclides in waste processed annually at a facility.

\subsection{NORMAL STACK RELEASE}

The models used to estimate dose for the individual and for the general population from normal stack releases are described in Sections 4.1.1 and 4.1.2, respectively. The doses are calculated as the product of an environment factor $\left(F_{E}\right)$ and a waste impact factor $(W)$. The environment factor is receptor-specific; however, the same waste impact factor is used for both individuals and the general population. The models include inhalation during plume passage, groundshine from contamination deposited during plume passage, and ingestion of food products harvested from the contaminated area. For the inhalation and groundshine pathways, the CAP88-PC (EPA 1992) methodology was followed for one specific meteorological category (i.e., stability class $\mathrm{D}$ with a $4-\mathrm{m} / \mathrm{s}$ wind). For the ingestion pathway, further assumptions were made regarding consumption rates and agricultural productivity. 


\subsubsection{Model for Doses to an Individual}

A model was developed to estimate the doses to individuals at five TSD stack-release facilities previously studied. Those studies used site-specific data and were modeled with the EPA CAP88-PC computer code (EPA 1992). In the previous studies, the following parameters were determined to be most significant:

- Total activity of all isotopes processed annually at a TSD facility and

- Vertical and horizontal atmospheric dispersion.

Vertical dispersion is affected by release height, as well as the location of the individual relative to the release point. This dependence reflects components of the Gaussian plume model. In the TSD-DOSE model, the dose to the individual is expressed as the product of an environment factor $\left(F_{E}\right)$ and a waste impact factor $(W)$ :

$$
D_{I S}=F_{E} \cdot W
$$

where

$$
\begin{aligned}
& D_{I S}=\text { dose to individual from stack operations (mrem), } \\
& F_{E}=\text { environment factor for an individual }\left(\mathrm{yr} / \mathrm{m}^{3}\right), \text { and } \\
& W=\text { waste impact factor }\left(\mathrm{mrem} \cdot \mathrm{m}^{3} / \mathrm{yr}\right)
\end{aligned}
$$

The factors $F_{E}$ and $W$ were developed and defined specifically for the TSD-DOSE model. The individual environment factor is defined as the time-integrated $\chi / Q$ of a Gaussian plume for stability class $D$ with a $4-\mathrm{m} / \mathrm{s}$ wind:

$$
F_{E}=\frac{3 \cdot F_{d i r}}{V_{w} \cdot R \cdot \sigma_{z}} \cdot \mathrm{e}^{-\frac{1}{2}\left(\frac{H_{e}}{\sigma_{z}}\right)^{2}}
$$

where

$$
F_{E}=\text { environment factor for an individual }\left(\mathrm{yr} / \mathrm{m}^{3}\right) \text {, }
$$


$F_{d i r}=$ fraction of time the wind is blowing from the release point toward the individual,

$H_{e}=$ effective stack height (m), defined as

$H_{E}=H+1.5 \cdot D \cdot V_{x} / V_{w}$

where

$D=$ stack diameter $(\mathrm{m})$,

$V_{x}=$ exit velocity from $\operatorname{stack}(\mathrm{m} / \mathrm{s})$,

$H=\operatorname{stack}$ height $(\mathrm{m})$,

$V_{w}=$ wind $\operatorname{speed}(\mathrm{m} / \mathrm{s})$

$R=$ distance of individual from the point of release $(\mathrm{m})$, and

$\sigma_{z}=$ vertical dispersion coefficient $(\mathrm{m})$, defined as:

$\sigma_{z}=\frac{a_{z} R}{\sqrt{1+b_{z} \cdot R}}$

where $a_{z}$ and $b_{z}$ are coefficients for Pasquill stability category D.

The effective stack height $\left(H_{e}\right)$ incorporates the actual physical height of the stack as well as the plume rise by taking into account the effluent stack gas velocity, the stack diameter, and the wind velocity. The vertical dispersion coefficient $\left(\sigma_{z}\right)$ is as defined in the CAP88-PC manual (EPA 1992) for a wind speed of $4 \mathrm{~m} / \mathrm{s}$.

The waste impact factor is expressed as the summation of the product of three radionuclide-dependent factors:

$$
W=\sum_{i} Q_{i} \cdot R F_{i} \cdot D C F_{i}^{\prime}
$$


where

$$
\begin{aligned}
W & =\text { waste impact factor }\left(\mathrm{mrem} \cdot \mathrm{m}^{3} / \mathrm{yr}\right) \\
Q_{i} & =\text { incinerated activity for radionuclide } i(\mathrm{Ci}), \\
R F_{i} & =\text { radionuclide-specific release fraction (dimensionless), and } \\
D C F_{i}^{\prime} & =\text { effective dose conversion factor }\left(\mathrm{mrem} / \mathrm{Ci} \cdot \mathrm{m}^{3} / \mathrm{yr}\right) .
\end{aligned}
$$

The release fraction (RF) is estimated by subtracting the removal efficiency (RE) from 1 (i.e., I - RE). The RE of several TSD facilities studied ranged from 0 to 0.99 , depending on the filtration system at each facility. RE should be adjusted to appropriate site-specific values.

The effective dose conversion factor is the summation of the product of pathway-specific dose conversion factors and pathway-specific components:

$$
D C F_{i}^{\prime}=D C F_{i n h_{i}} \cdot B R+V_{D} \cdot T_{e f f} \cdot\left(D C F_{e x x_{i}}+D C F_{i n g_{i}} \cdot F T F \cdot F_{i n g_{i}}\right)
$$

where

$$
\begin{aligned}
& D C F_{i n h_{i}}=\text { the dose conversion factor from the inhalation pathway for } \\
& \begin{aligned}
D C F_{\text {ing }_{i}}= & \text { the dose conversion factor from the ingestion pathway for } \\
& \text { radionuclide } \mathrm{i}(\mathrm{mrem} / \mathrm{Ci}) \text { (Eckerman et al. 1988), }
\end{aligned} \\
& \begin{aligned}
D C F_{\text {ext }}= & \text { the dose conversion factor from the groundshine external pathway for } \\
& \text { radionuclide } \mathrm{i}\left(\mathrm{mrem} / \mathrm{Ci} \cdot \mathrm{m}^{2} / \mathrm{yr}\right),
\end{aligned} \\
& B R=\text { average individual breathing rate }\left(\mathrm{m}^{3} / \mathrm{s}\right) \text {, } \\
& V_{D}=\text { deposition velocity }(\mathrm{m} / \mathrm{s}) \\
& F T F=\text { food transfer factor (dimensionless) }
\end{aligned}
$$




$$
\begin{aligned}
& F_{\text {ing }}=\begin{array}{l}
\text { the area of local agricultural land from which an individual consumes } \\
\text { food }\left(\mathrm{m}^{2} / \mathrm{yr}\right), \text { and }
\end{array} \\
& T_{\text {eff }}=\text { the effective exposure time }(\mathrm{yr}) .
\end{aligned}
$$

The inhalation pathway includes the inhalation dose conversion factor and the breathing rate. The external groundshine pathway includes the groundshine dose conversion factor, the deposition velocity, and the effective exposure time $\left(T_{\text {eff }}\right)$. The effective exposure time accounts for radionuclide decay and weathering:

$$
T_{e f f}=\frac{1-\mathrm{e}^{-T_{\text {exp }} \cdot \lambda^{\prime}}}{\lambda^{\prime}},
$$

where

$$
\begin{aligned}
\lambda^{\prime} & =\lambda_{\text {nuc }}+\lambda_{\text {met }} \\
\lambda_{\text {nuc }} & =\text { the radioactive decay constant }\left(\mathrm{yr}^{-1}\right), \text { and } \\
\lambda_{\text {met }} & =\text { loss rate constant for weathering }\left(\mathrm{yr}^{-1}\right) .
\end{aligned}
$$

The ingestion pathway includes the dose conversion factor for ingestion, the deposition velocity, the effective exposure time, the food transfer factor, and the ingestion rate. The ingestion rate was calculated by using CAP88-PC local consumption and U.S. average agricultural productivity. The ingestion pathway is the most sensitive to site-specific agricultural productivity. For facilities that show a high dose resulting from strontium, technetium, or tritium by using this model, the suggestion is that CAP88-PC be used in place of TSD-DOSE with all site-specific parameters.

\subsubsection{Model for Doses to the General Population}

The model for determining the dose to the general population is similar to that for the individual; however, the population environment factor is based on an area integral of the Gaussian plume:

$$
D_{p o p}=F_{E}^{p o p} \cdot W \cdot C F \text {, }
$$


where

$D_{\text {pop }}=$ dose to the population from stack operations (person-rem),

$F_{E}^{p o p}=$ environment factor for population (person- $\mathrm{yr} / \mathrm{m}^{3}$ ),

$W=$ waste impact factor as defined in Equation $22\left(\mathrm{mrem} \cdot \mathrm{m}^{3} / \mathrm{yr}\right)$, and

$C F=$ conversion factor: mrem to rem (0.001).

The environmental population factor is further defined as follows:

$$
F_{E}^{P o p}=\frac{f_{20} \cdot \rho_{20}+f_{50} \cdot \rho_{50}}{V_{D}}
$$

where

$$
\begin{aligned}
f_{20}= & \frac{0.805}{b_{20}+a_{50} \cdot H_{E}} \text { where } a_{20} \text { and } b_{20} \text { were calculated by using a Gaussian } \\
& \begin{array}{l}
\text { plume model with stability class } \mathrm{D} \text { and a windspeed of } 4 \mathrm{~m} / \mathrm{s} \text { and an } \\
\text { effective release height of } \mathrm{H}_{E} ;
\end{array}
\end{aligned}
$$

$f_{50}=\frac{0.805}{b_{50}+a_{50} \cdot H_{E}}-f_{20}$ where $a_{50}$ and $b_{50}$ were calculated by using a Gaussian plume model with stability class $D$ and a windspeed of $4 \mathrm{~m} / \mathrm{s}$ and an effective release height of $\mathrm{H}_{E}$;

$V_{D}=$ deposition velocity $(\mathrm{m} / \mathrm{s})$

$\rho_{20}=$ average population density within $20 \mathrm{mi}$ of the release point (person $/ \mathrm{mi}^{2}$ ); and

$\rho_{50}=$ average population density between 20 and $50 \mathrm{mi}$ from the release point (person/ $/ \mathrm{mi}^{2}$ ). 


\subsection{LANDFILL OPERATIONS}

During the landfill operations, unloading of soil or incineration residues from trucks might generate a small amount of airborne respirable particulates (less than $10 \mu \mathrm{m}$ in size). Materials might also become airborne as a result of the mixing, leveling, and rolling of waste deposited in the landfill. Water is often added to the travel surface within the landfill to reduce particulate emissions.

A separate equation was needed to calculate the individual environment factor resulting from landfill operations because the stack release model did not accurately extend to a landfill ground release. The population environment factor equation (Equation 26) still applies for landfill operations; however, the release height is zero. The dose to the individual from landfill operations is calculated as follows:

$$
D_{I L}=F_{E} \cdot W_{S}
$$

where

$$
\begin{aligned}
& D_{I L}=\text { dose to the individual from landfill operations (mrem), } \\
& F_{E}=\text { landfill environment factor for the individual }\left(\mathrm{yr} / \mathrm{m}^{3}\right) \text {, and } \\
& W_{S}=\text { waste impact factor from landfill operations }\left(\mathrm{mrem} \cdot \mathrm{m}^{3} / \mathrm{yr}\right) \text {. }
\end{aligned}
$$

The waste impact factor is calculated as defined in Equation 22; however, the airborne respirable release fraction is based on EPA methodology. This airborne respirable particulate fraction, $3 \times 10^{-7}$, is assumed for truck unloading operations (EPA 1989). This factor takes into account particle size, mean windspeed, and material moisture content. The landfill environment factor is defined as follows:

$$
F_{E}=\frac{4 \cdot F_{d i r}}{0.5 \cdot V_{w} \cdot R \cdot \sigma_{z}}
$$

where all terms are as defined for Equation 21. 


\section{VERIFICATION AND BENCHMARKING OF TSD-DOSE MODEL}

Verification and benchmarking of the worker and off-site public exposure models incorporated into TSD-DOSE are discussed in this chapter. Verification is a process used to ensure that the calculations are being performed by the code as intended. Verification of TSDDOSE results was performed in a step-by-step fashion with spreadsheets generated by Microsoft Excel. In contrast to verification, benchmarking consists of comparing results of the subject code against results of previously accepted codes to show that the results of the subject code are reasonable. For the worker analysis, external doses were compared with results from the Monte Carlo N-Particle (MCNP) transport code (Briesmeister 1993). For the off-site analysis, TSDDOSE was benchmarked against CAP88-PC for eight commercial TSD facilities.

\subsection{VERIFICATION AND BENCHMARKING OF WORKER DOSES}

\subsubsection{Verification of Internal Doses to Workers}

Verification of the internal dose to workers was performed for all of the operations in which workers would be involved. These operations include sampling and inspection, normal stack release, landfill, and incinerator maintenance operations.

The models for calculating internal dose to workers for the various operations specified in Equations 15, 16a, 17, 18 and 19 of Section 3.2 were inserted into a Microsoft Excel spreadsheet (Figure 3). The annual internal doses to the on-site worker due to normal stack releases are calculated according to Equation 17 in Section 3.2 by summing the doses from fumigation and building-wake effects.

The values for the parameters required by Equations 15, 16a, 17, 18, and 19 are provided in Tables 3 through 6 . The spreadsheet was used to calculate the values for both the derived parameters and the total collective dose resulting from worker operations. Verification was performed for californium-244, tritium, radium-226, and thorium-230. The internal dose to a worker from the specific operations estimated in the Excel spreadsheet was then compared with the internal dose obtained with TSD-DOSE. As shown in Table 7, the internal doses to workers from various operations calculated with the spreadsheet are identical to the internal doses obtained by using TSD-DOSE, indicating that the code performs as intended. 


\begin{tabular}{|c|c|c|c|c|c|c|c|c|}
\hline \multirow{2}{*}{$\begin{array}{c}\text { Dint/radium-226 }= \\
\text { (mrem) }\end{array}$} & $\bar{A}^{*}$ & RPC" & $D F^{*}$ & $E T^{*}$ & $\mathrm{BR}^{*}$ & $1 / \mathrm{PF}^{*}$ & 1/Mdrum" & $\mathrm{DCF}$ \\
\hline & 1 & 10 & 0.033 & 300 & $3.33 E-04$ & $1 / 10$ & \begin{tabular}{|c|}
$6.87 \mathrm{E}-09$ \\
\end{tabular} & $8.60 \mathrm{E}-03$ \\
\hline \begin{tabular}{|c|}
$2.0 \mathrm{E}-13$ \\
\end{tabular} & $\mathrm{pCl}$ & $\mathrm{mg} / \mathrm{ms}$ & & $\sec$ & $\mathrm{m} 3 / \mathrm{s}$ & & $1 / \mathrm{mg}$ & mrem/pCi \\
\hline
\end{tabular}

Tritium Release:

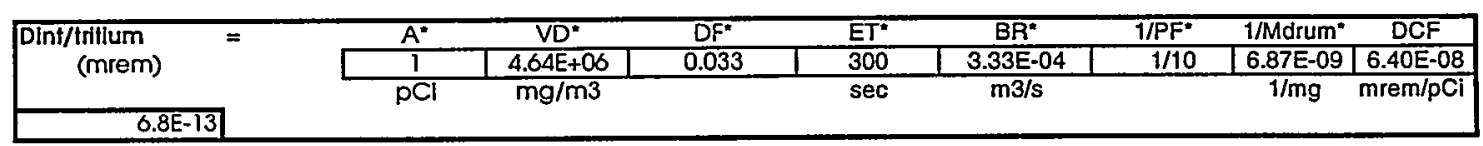

2. Equation Used in Evaluating Internal Dose to Workers from Normal Stack Release Operaration Buildina Wake Effect:

\begin{tabular}{|c|c|c|c|c|c|c|}
\hline Dint/radium-226 = & $A^{*}$ & SRF" & $\mathrm{BR}^{*}$ & X/Q Wake* & Bldg. Wake & DCF \\
\hline (mrem) & 1 & $5.00 \mathrm{E}-04$ & $3.3 \mathrm{E}-04$ & $5.00 \mathrm{E}-05$ & 0.5 & $8.60 \mathrm{E}-03$ \\
\hline
\end{tabular}

Fumigation Condition:

\begin{tabular}{|c|c|c|c|c|c|c|}
\hline \multirow{3}{*}{$\begin{array}{c}\text { Dint/radium-226 } \\
\text { (mrem) }\end{array}$} & $A^{*}$ & SRF" & $B R^{*}$ & X/Q fumg* & fumigation" & DCF \\
\hline & \multirow{2}{*}{$\frac{1}{\mathrm{pCl}}$} & $5.00 E-04$ & $3.33 E-04$ & $1.00 \mathrm{E}-04$ & 0.01 & $8.60 \mathrm{E}-03$ \\
\hline & & & $\mathrm{m} 3 / \mathrm{s}$ & $\mathrm{s} / \mathrm{m} 3$ & & mrem/pCi \\
\hline
\end{tabular}

3. Equation Used in Evaluating Dose to Workers from Landfill Operations

\begin{tabular}{|ccc|c|c|c|c|c|c|}
\hline $\begin{array}{c}\text { Dint/radlum-226 } \\
\text { (mrem) }\end{array}$ & \multicolumn{2}{c|}{$\mathrm{A}^{*}$} & $\mathrm{RPC}^{*}$ & $\mathrm{BR}^{*}$ & $\mathrm{ET}^{*}$ & $1 / \mathrm{Mload}^{*}$ & $1 / \mathrm{PF}^{*}$ & DCF \\
\hline $1.00 \mathrm{E}+00$ & $1.00 \mathrm{E}+00$ & $3.33 \mathrm{E}-04$ & $9.00 \mathrm{E}+02$ & $5.62 \mathrm{E}-11$ & $1.00 \mathrm{E}+00$ & $8.60 \mathrm{E}-03$ \\
\hline & $\mathrm{DCl}$ & $\mathrm{mg} / \mathrm{m3}$ & $\mathrm{m3} / \mathrm{s}$ & $\mathrm{s}$ & $1 / \mathrm{mg}$ & & $\mathrm{mrem} / \mathrm{pCi}$ \\
\hline
\end{tabular}

4. Equation Used in Evaluating Dose to Workers from Maintenance of the Incinerator System

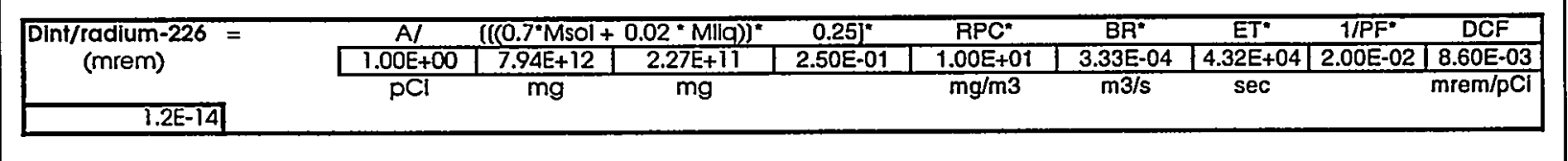

FIGURE 3 Verification of Internal Doses to Workers from Sampling and Inspection, Normal Stack Release, Landfill, and Incinerator Maintenance Operations for Radium-226 
TABLE 3 Parameters Used in Evaluating Internal Dose to Workers from Sampling and Inspection Operations

Value Used ${ }^{\mathrm{a}}$

\begin{tabular}{lccc} 
& & \multicolumn{2}{c}{ Value Used $^{\mathrm{a}}$} \\
\cline { 3 - 4 } Parameter & Unit & Particulate Release & Tritium Release \\
\hline & & & \\
Activity (A) & $\mathrm{pCi}$ & 1 & 1 \\
Respirable Particulate Concentration (RPC) & $\mathrm{mg} / \mathrm{m}^{3}$ & 10 & $\mathrm{NA}$ \\
Vapor Density (VD) & $\mathrm{mg} / \mathrm{m}^{3}$ & & $4.64 \times 10^{6}$ \\
Dilution Factor (DF) & & $1 / 30$ & $1 / 30$ \\
Exposure Time (ET) & $\mathrm{s}$ & 300 & 300 \\
Breathing Rate (BR) & $\mathrm{m}^{3} / \mathrm{s}$ & $3.33 \times 10^{-4}$ & $3.33 \times 10^{-4}$ \\
Respiratory Protection Factor (RPF) & & 10 & 10 \\
Mass of Drumb (Mdrum) & $\mathrm{mg}$ & $1.46 \times 10^{8}$ & $1.46 \times 10^{8}$ \\
Dose Conversion Factors (DCFs) & $\mathrm{mrem} / \mathrm{pCi}$ & & \\
Californium-244 & & 0.248 & $\mathrm{NA}$ \\
Tritium & & $\mathrm{NA}$ & $6.4 \times 10^{-8}$ \\
Radium-226+D & & $8.6 \times 10^{-3}$ & $\mathrm{NA}$ \\
Thorium-230 & & 0.326 & $\mathrm{NA}$ \\
\hline
\end{tabular}

${ }^{2} \mathrm{NA}=$ not applicable.

${ }^{b}$ Mass of Drum (Mdrum) $=$ density $\times$ volume: $0.7 \mathrm{~g} / \mathrm{cm}^{3} \times 2.08 \times 105 \mathrm{~cm}^{3} \times 1,000 \mathrm{mg} / \mathrm{g}=1.46 \times$ $10^{8} \mathrm{mg}$.

TABLE 4 Parameters Used in Evaluating Internal Dose to Workers from Normal Stack Release

\begin{tabular}{lccc}
\hline & & \multicolumn{2}{c}{ Value Used $^{\mathrm{a}}$} \\
\cline { 3 - 4 } \multicolumn{1}{c}{ Parameter } & & $\begin{array}{c}\text { Building Wake } \\
\text { Effect }\end{array}$ & $\begin{array}{c}\text { Fumigation } \\
\text { Condition }\end{array}$ \\
\cline { 3 - 4 } & Unit & & \\
Activity (A) & $\mathrm{pCi}$ & 1 & 1 \\
Stack Release Fraction (SRF) & & $5 \times 10^{-4}$ & $5 \times 10^{-4}$ \\
Radium-226 and Thorium-230 & & $1 \times 10^{-2}$ & $1 \times 10^{-2}$ \\
Californium-244 & & $9 \times 10^{-1}$ & $9 \times 10^{-1}$ \\
Tritium & & $3.33 \times 10^{-4}$ & $3.33 \times 10^{-4}$ \\
Breathing Rate (BR) & $\mathrm{m}^{3} / \mathrm{s}$ & $5 \times 10^{-5}$ & $1 \times 10^{-4}$ \\
Atmospheric Dispersion Factor ( $(\mathrm{Q} / \mathrm{Q})$ & $\mathrm{s} / \mathrm{m}^{3}$ & 0.5 & $\mathrm{NA}$ \\
Building Wake Effect Fraction & & $\mathrm{NA}$ & 0.01 \\
Fumigation Condition Fraction & & & \\
Dose Conversion Factors (DCF) & $\mathrm{mrem} / \mathrm{pCi}$ & 0.248 & 0.248 \\
Californium-244 & & $6.4 \times 10^{-8}$ & $6.4 \times 10^{-8}$ \\
Tritium & & $8.6 \times 10^{-3}$ & $8.6 \times 10^{-3}$ \\
Radium-226+D & & 0.326 & 0.326 \\
Thorium-230 & & & \\
\hline
\end{tabular}

a $\mathrm{NA}=$ not applicable. 
TABLE 5 Parameters Used in Evaluating Internal Dose to Workers from Landfill Operations

\begin{tabular}{lcc}
\hline \multicolumn{1}{c}{ Parameter } & Unit & Value Used \\
\hline & $\mathrm{pCi}$ & 1 \\
Activity (A) & $\mathrm{mg} / \mathrm{m}^{3}$ & 1 \\
Respirable Particulate Concentration (RPC) & $\mathrm{m}^{3} / \mathrm{s}$ & $3.33 \times 10^{-4}$ \\
Breathing Rate (BR) & $\mathrm{s}$ & 900 \\
Exposure Time (ET) & $\mathrm{mg}$ & $1.8 \times 10^{10}$ \\
Mass of Load (Mload) & & 1 \\
Respiratory Protection Factor (RPF) & $\mathrm{mrem} / \mathrm{pCi}$ & \\
Dose Conversion Factors (DCFs) & & 0.248 \\
Californium-244 & & $6.4 \times 10^{-8}$ \\
Tritium & & $8.6 \times 10^{-3}$ \\
Radium-226+D & & 0.326 \\
Thorium-230 & & \\
\hline
\end{tabular}

${ }^{\text {a }}$ Mass of Load $($ Mload $)=$ density $\times$ volume: $1.4 \mathrm{~g} / \mathrm{cm}^{3} \times 1.27 \times 10^{7} \mathrm{~cm}^{3} \times$ $1,000 \mathrm{mg} / \mathrm{g}=1.8 \times 10^{10} \mathrm{mg}$.

TABLE 6 Parameters Used in Evaluating Internal Dose to Workers from Incinerator Maintenance

\begin{tabular}{lcc}
\hline \multicolumn{1}{c}{ Parameter } & Unit & Value Used \\
\hline & & \\
Activity (A) & $\mathrm{pCi}$ & 1 \\
Fraction of Solid Waste (Msol) & & 0.7 \\
Fraction of Liquid Waste (Mliq) & & 0.02 \\
Mass of Waste (Msol) or (Mliq) & $\mathrm{mg}$ & $1.13 \times 10^{13}$ \\
Respirable Particulate Concentration (RPC) & $\mathrm{mg}^{\mathrm{a}} \mathrm{m}^{3}$ & 10 \\
Breathing Rate (BR) & $\mathrm{m}^{3} / \mathrm{s}$ & $3.33 \times 10^{-4}$ \\
Exposure Time (ET) & $\mathrm{s}$ & $4.32 \times 10^{4}$ \\
Respiratory Protection Factor (RPF) & & 50 \\
Dose Conversion Factors (DCFs) & $\mathrm{mrem} / \mathrm{pCi}$ & \\
Californium-244 & & 0.248 \\
Tritium & & $6.4 \times 10^{-8}$ \\
Radium-226+D & & $8.6 \times 10^{-3}$ \\
Thorium-230 & & 0.326 \\
\hline
\end{tabular}

a Mass of Solid Waste (Msol) or Mass of Liquid Waste (Mliq) = $25,000,000 \mathrm{lb} \times 453.6 \mathrm{~g} / \mathrm{lb} \times 1,000 \mathrm{mg} / \mathrm{g}=1.13 \times 10^{13} \mathrm{mg}$. 
TABLE 7 Comparison of Internal TSD-DOSE Model Predictions with Spreadsheet Calculations for the Worker from Sampling and Inspection, Normal Stack Release, Landfill, and Incinerator Maintenance Operations

\begin{tabular}{|c|c|c|c|c|c|c|c|c|}
\hline Operation & Spreadsheet & TSD Model & Spreadsheet & TSD Model & Spreadsheet & TSD Model & Spreadsheet & TSD Model \\
\hline $\begin{array}{l}\text { Sampling and Inspection } \\
\text { Particulate release }\end{array}$ & $5.7 \times 10^{-12}$ & $5.7 \times 10^{-12}$ & $6.8 \times 10^{-13}$ & $6.8 \times 10^{-13}$ & $2.0 \times 10^{-13}$ & $2.0 \times 10^{-13}$ & $7.4 \times 10^{-12}$ & $7.4 \times 10^{-12}$ \\
\hline Landfill & $4.2 \times 10^{-12}$ & $4.2 \times 10^{-12}$ & $1.1 \times 10^{-18}$ & $1.1 \times 10^{-18}$ & $1.4 \times 10^{-13}$ & $1.4 \times 10^{-13}$ & $5.5 \times 10^{-12}$ & $5.5 \times 10^{-12}$ \\
\hline Incinerator Maintenance & $3.5 \times 10^{-13}$ & $3.5 \times 10^{-13}$ & NA & NA & $1.2 \times 10^{-14}$ & $1.2 \times 10^{-14}$ & $4.6 \times 10^{-13}$ & $4.6 \times 10^{-13}$ \\
\hline
\end{tabular}




\subsubsection{Benchmarking of External Doses to Workers}

Results of the worker external dose model used in TSD-DOSE were benchmarked with MCNP computations for various source configurations. In general, the external worker doses from TSD-DOSE compare favorably with those of MCNP (Kamboj 1998).

\subsection{VERIFICATION AND BENCHMARKING OF OFF-SITE PUBLIC DOSE}

Verification of the TSD-DOSE off-site public exposure models was performed in a stepby-step fashion with spreadsheets generated by Microsoft Excel-97. The verification results are summarized in Sections 5.2.1 through 5.2.3. Benchmarking was done with the EPA's CAP88-PC code (EPA 1992); results are summarized in Section 5.2.4.

\subsubsection{Verification of Effective Dose Conversion Factors}

Verification of the effective dose conversion factors was conducted for cobalt- 60 and uranium-238. These isotopes were selected because of their contrasting radioactive half-lives and differences associated with the major pathways that determine their effective dose conversion factors. The half-lives of cobalt-60 and uranium-238 are 5.3 years and 4.5 billion years, respectively. The main contributor to the effective dose conversion factor for cobalt-60 is the groundshine pathway; the main contributor for uranium-238 is the inhalation pathway.

Figures 4 and 5 present the verification of the effective dose conversion factors for cobalt-60 and uranium-238, respectively. The models specified in Equations 23 and 24 of Section 4.1.1 were inserted into a Microsoft Excel spreadsheet. The values used for the parameters are directly below their names in the spreadsheet. Some of the more common parameters are given in Table 8. (If a parameter for a model is derived from a previous equation, then the name of that parameter is displayed in a bolded font.)

After the models and the parameters were entered, the spreadsheet calculated the effective dose conversion factor for the specified radionuclides. The values obtained from the Excel spreadsheet were then compared with the effective dose conversion factors from TSD-DOSE. As shown in Figures 4 and 5, the effective dose conversion factors for cobalt-60 and uranium-238 derived from the verification spreadsheets are identical to the values calculated by TSD-DOSE, confirming that the code is performing as expected. 


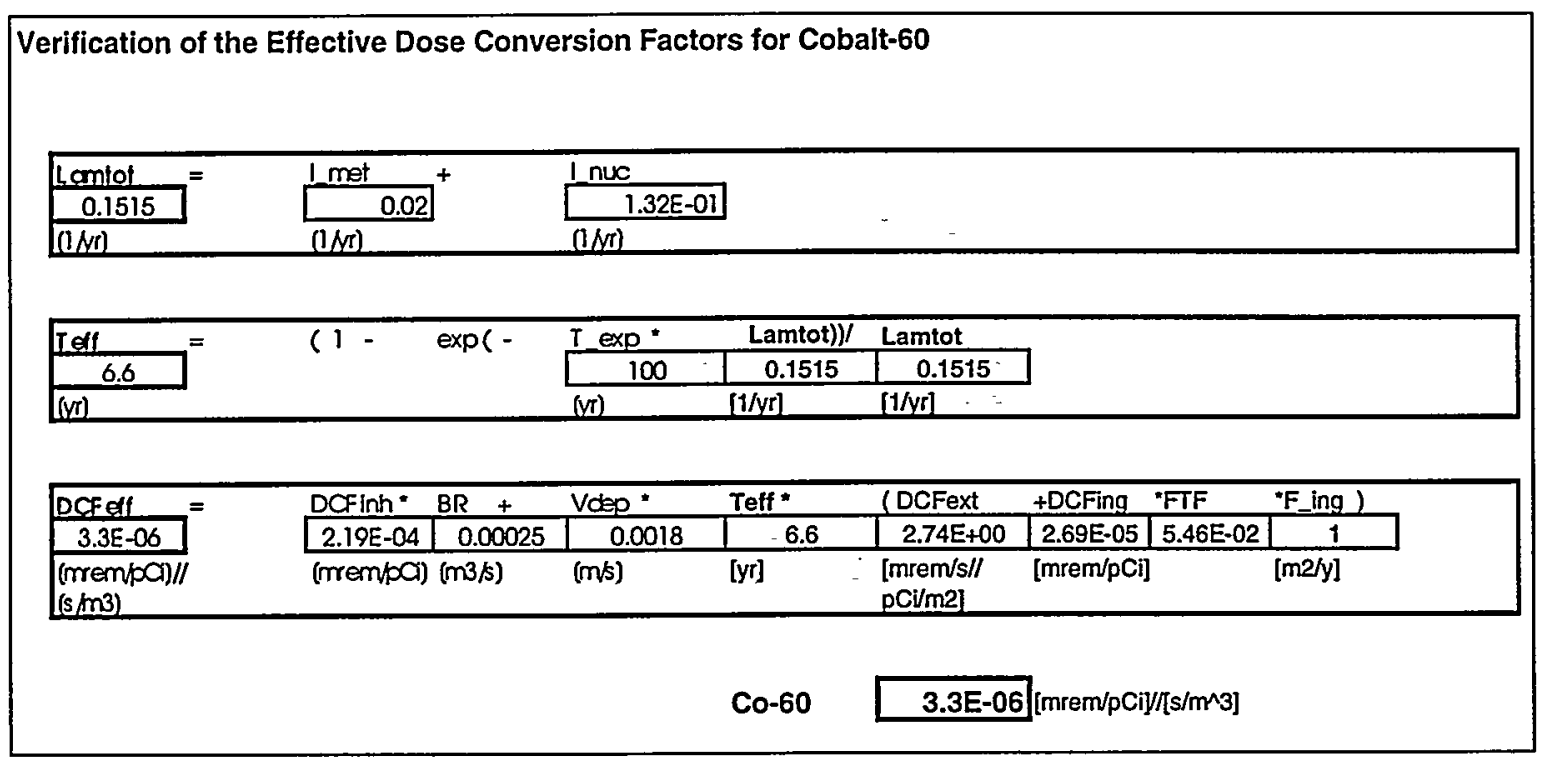

\section{FIGURE 4 Verification of the Effective Dose Conversion Factor for Cobalt-60}

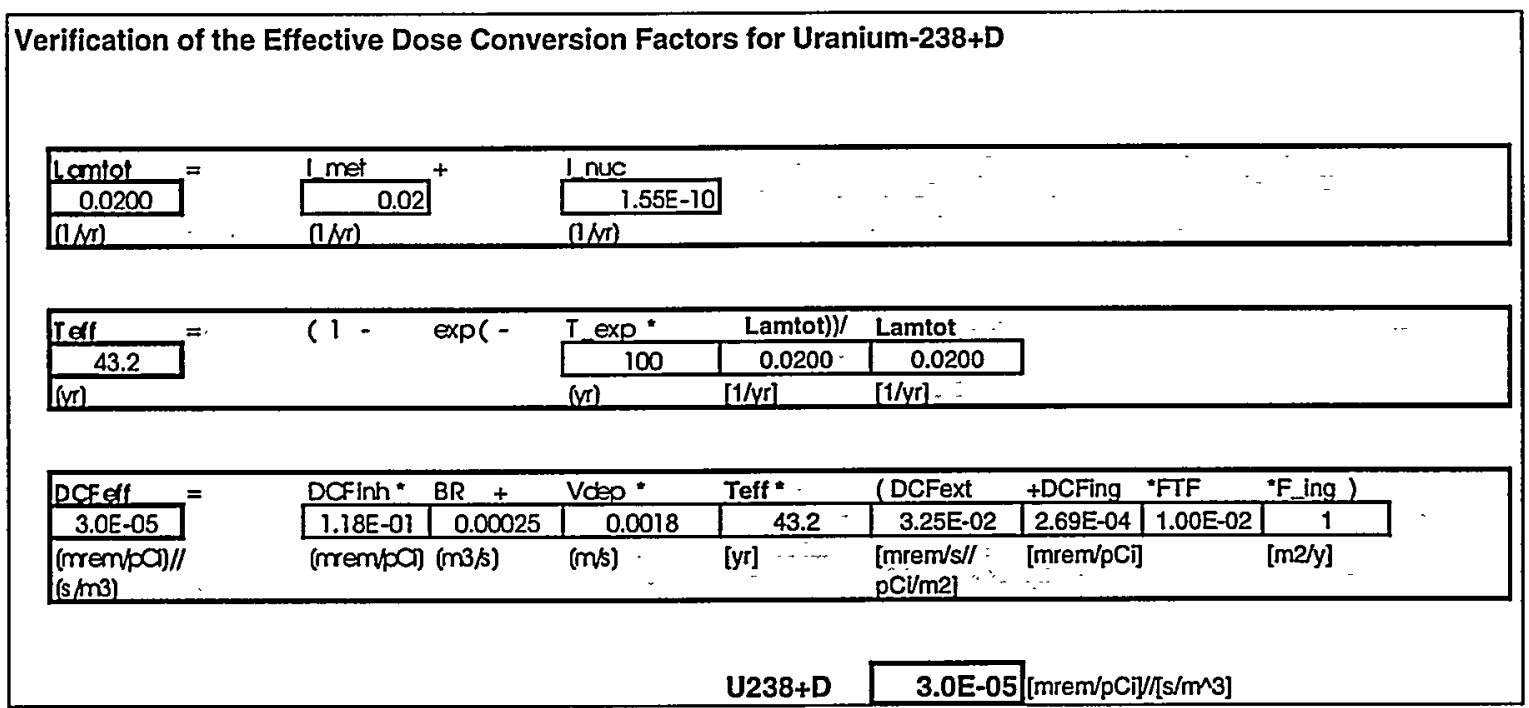

FIGURE 5 Verification of the Effective Dose Conversion Factor for U-238+D 
TABLE 8 General Parameters and Values Used for the Off-Site Exposure Models in TSD-DOSE

\begin{tabular}{|c|c|c|}
\hline General Parameter & Unit & $\begin{array}{l}\text { Value } \\
\text { Used }\end{array}$ \\
\hline Breathing rate (BR) & $\mathrm{m}^{3} / \mathrm{s}$ & 0.00025 \\
\hline Deposition velocity (vdep) & $\mathrm{m} / \mathrm{s}$ & 0.0018 \\
\hline Weathering rate constant (1_met) & $1 / \mathrm{yr}$ & 0.02 \\
\hline $\begin{array}{l}\text { Area of local agricultural land from } \\
\text { which an individual consumes food (F_ing) }\end{array}$ & $\mathrm{m}^{2} / \mathrm{yr}$ & 1 \\
\hline Conversion from $\mathrm{cm}^{\wedge} 2$ to $\mathrm{m}^{\wedge} 2$ (cm_m) & $\mathrm{cm}^{2} / \mathrm{m}^{2}$ & 0.0001 \\
\hline Exposure time (T_exp) & $\mathrm{yr}$ & 100 \\
\hline apop20 & $1 / \mathrm{m}$ & 0.172 \\
\hline bpop20 & Dimensionless & 9.325 \\
\hline apop50 & $1 / \mathrm{m}$ & 0.0786 \\
\hline bpop50 & Dimensionless & 6.79 \\
\hline Parameter for sigma $z$ (az) & Dimensionless & 0.07653 \\
\hline Parameter for sigma $\mathrm{z}(\mathrm{bz})$ & $1 / \mathrm{m}$ & 0.0015 \\
\hline Windspeed for plume calculation (ws) & $\mathrm{m} / \mathrm{s}$ & 4 \\
\hline Population dose correction factor (pop_f) & Dimensionless & 0.805 \\
\hline Conversion from feet to meters ( $\left.c_{-} \mathrm{ft} \_\mathrm{m}\right)$ & $\mathrm{m} / \mathrm{ft}$ & 0.3048 \\
\hline Conversion from year to seconds ( $c_{-} \mathrm{yr}_{-} \mathrm{s}$ ) & $\mathrm{yr} / \mathrm{s}$ & $3.15 E+07$ \\
\hline $\begin{array}{l}\text { Fraction of time the wind blows in the } \\
\text { direction (f_dir) }\end{array}$ & Dimensionless & 0.5 \\
\hline Stack release fraction (RF_stack) & Dimensionless & 0.05 \\
\hline Landfill release fraction (RF_land) & Dimensionless & $3.00 \mathrm{E}-07$ \\
\hline
\end{tabular}




\subsubsection{Verification of Off-Site Individual Model}

The verification procedure for the off-site individual model for incineration operations was identical to the procedure used to verify the dose conversion factor. The models specified in Equations 20 through 24 of Section 4.1.1 were inserted into a Microsoft Excel spreadsheet. As shown in Figure 6 , the dose to the individual from incineration operations calculated by TSD-DOSE is identical to the verification spreadsheet results.

For calculating the dose to the individual from landfill operations, the release fraction in Equation 22 of Section 4.1.1 was set to $3 \times 10^{-7}$, and the environment factor for the individual was estimated by using Equation 28 of Section 4.2. As shown in Figure 7, the individual dose from landfill operations calculated by TSD-DOSE is identical to the dose estimated with the verification spreadsheet.

\subsubsection{Verification of Off-Site Population Model}

Figure 8 presents the verification of the off-site population dose for incineration operations for cobalt-60. The models specified in Equations 22 through 26 of Sections 4.1.1 and 4.1.2 were inserted into a Microsoft Excel spreadsheet. The values for the required parameters are provided directly below their names in the spreadsheet. (If a parameter for a model was derived from a previous equation, then the name of that parameter is displayed in a bolded font.) The spreadsheet then calculated the values for both the derived parameters and the total collective dose resulting from incineration operations. The collective dose estimated in the Excel spreadsheet was then compared with the collective dose obtained from TSD-DOSE. As shown in the figure, the collective dose values are identical.

To calculate the dose to the off-site population from landfill operations, it was assumed that there is a ground-level release of material; consequently, the effective release height $\left(\mathrm{H}_{\mathrm{E}}\right)$ is zero. Furthermore the airborne respirable particulate release fraction was estimated at $3 \times 10^{-7}$ on the basis of EPA methodology (EPA 1989). Figure 9 presents the verification of the off-site population dose model for landfill operations for cobalt-60. As shown in the figure, the collective dose from landfill operations calculated with the verification spreadsheets is identical to that calculated by TSD-DOSE.

\subsubsection{Benchmarking of Off-Site Public Doses}

Comparisons between the off-site public doses calculated with the TSD-DOSE model and those obtained with CAP88-PC (EPA 1992) are shown in Table 9 and are illustrated in Figures 10 and 11 for the off-site individual and for the general population, respectively. 


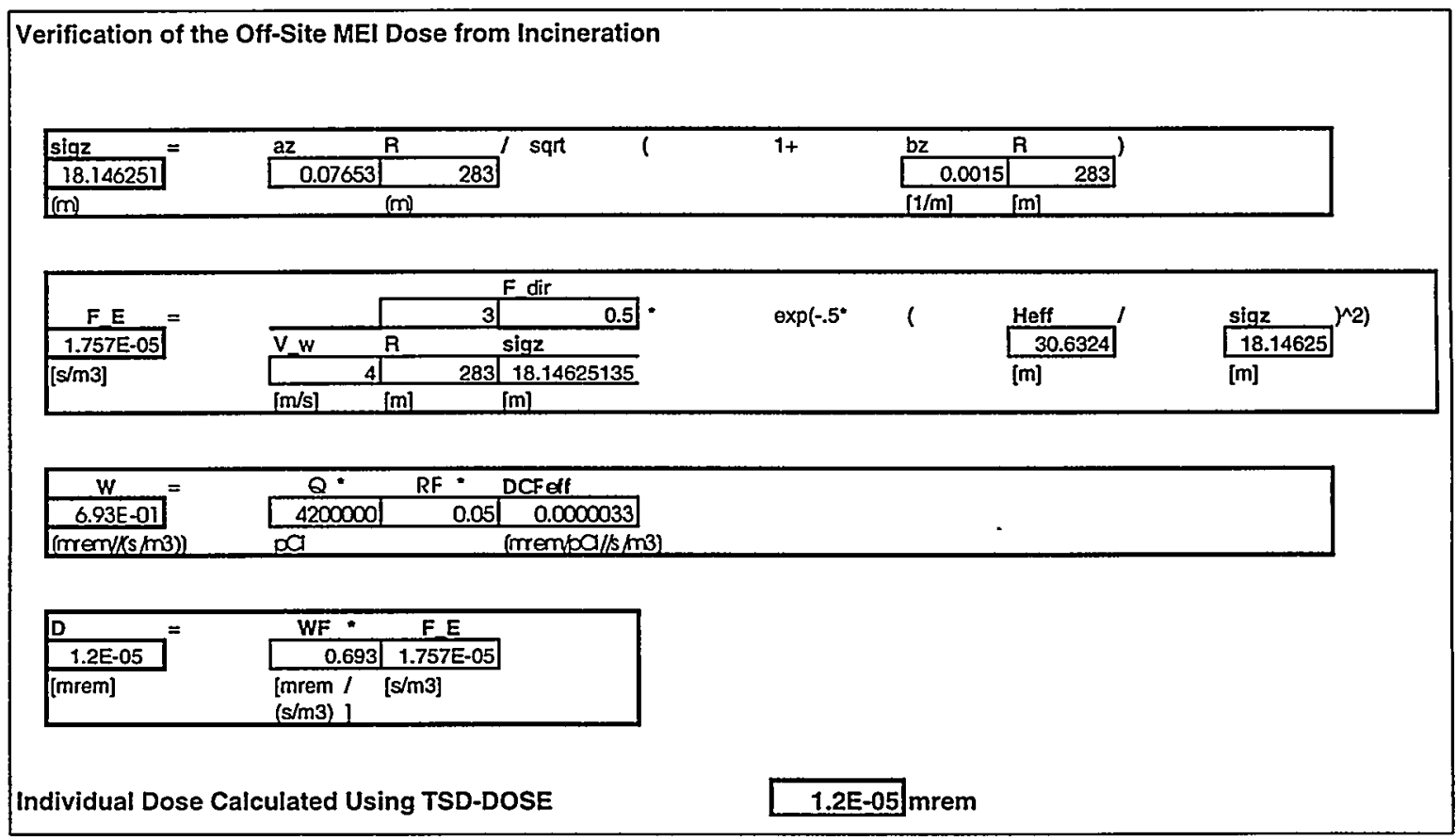

FIGURE 6 Verification of the Off-Site Individual Dose from Incineration Operations for Cobalt-60

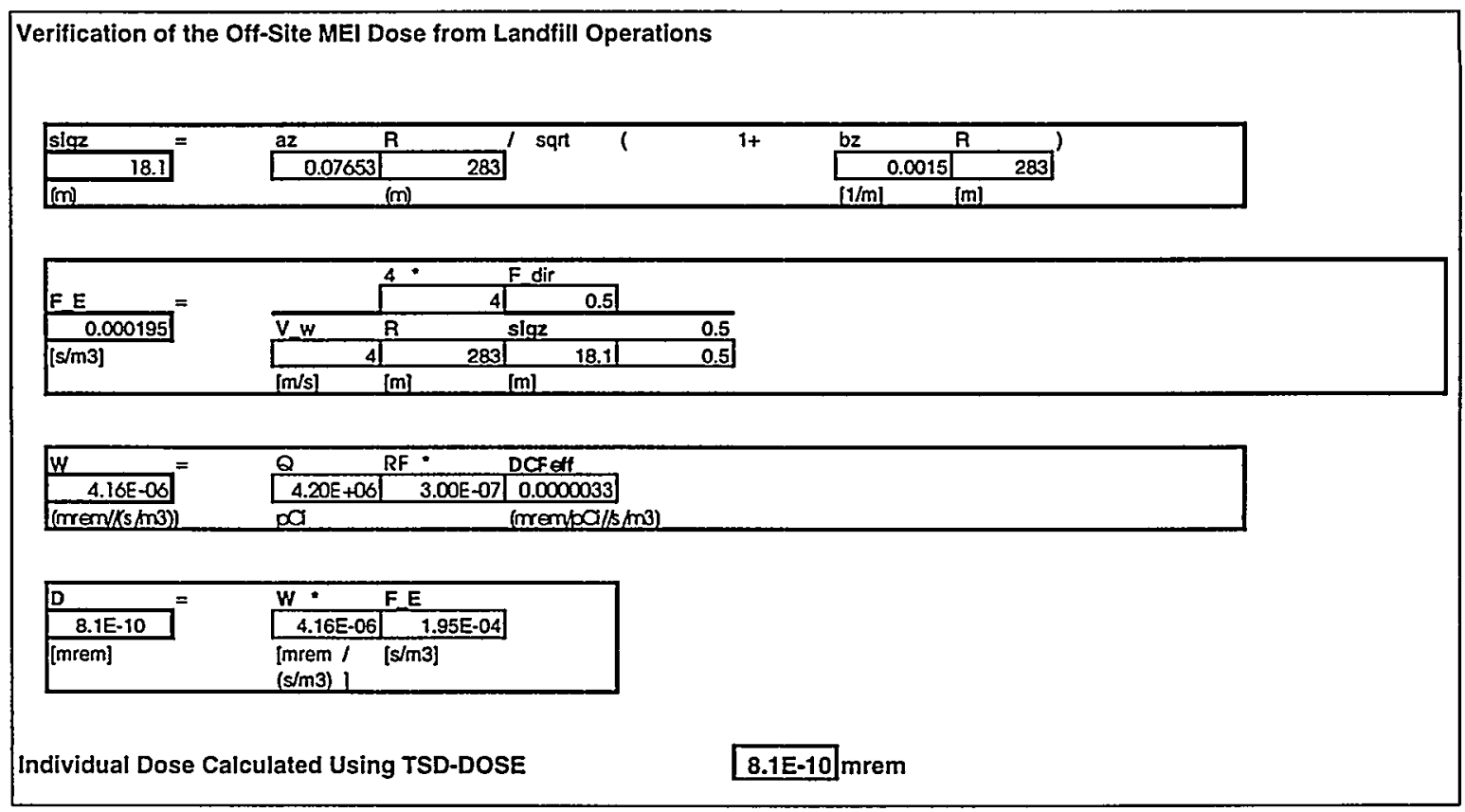

FIGURE 7 Verification of the Off-Site Individual Dose from Landfill Operations for Cobalt-60 


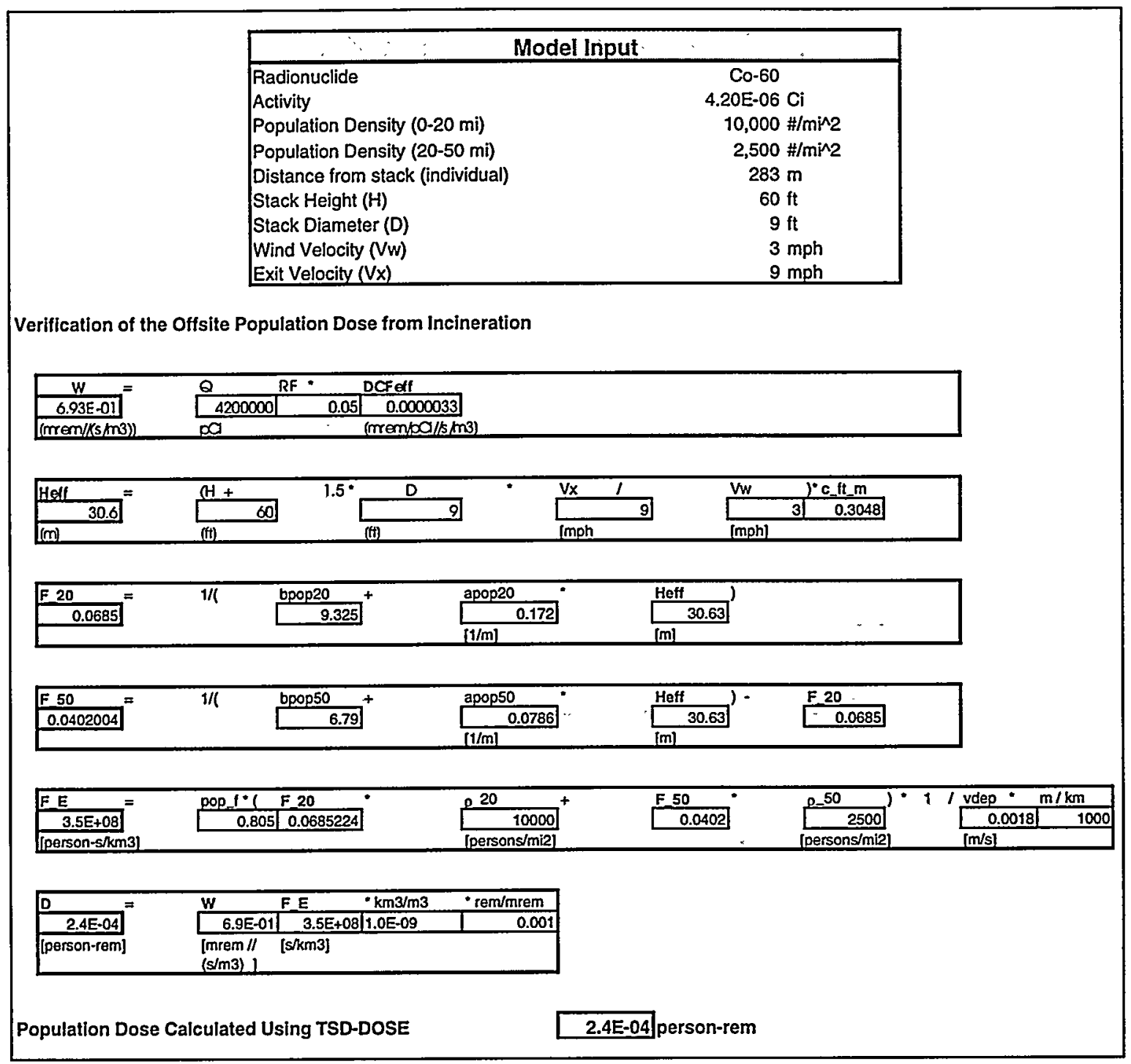

\section{FIGURE 8 Verification of the Off-Site Population Dose from Incineration Operations for Cobalt-60}

The facilities chosen for benchmarking were obtained from detailed radiological dose assessments for eight TSD facilities. Site-specific input parameters were used for the benchmarking report, and the released activity was primarily from uranium isotopes. For the facilities with stack releases, the results generally agree to within $35 \%$ for the off-site individual and within $30 \%$ for the general population.

The radionuclides incorporated into TSD-DOSE were also individually benchmarked against CAP88-PC for a unit release of $1 \mathrm{Ci}$. A site previously studied was chosen for comparative analysis. Figures 12 and 13 illustrate the comparison for individual and population doses, respectively. The radionuclide-specific doses calculated with TSD-DOSE for both individual and population are within a factor of 10 of the results from CAP88-PC. For 


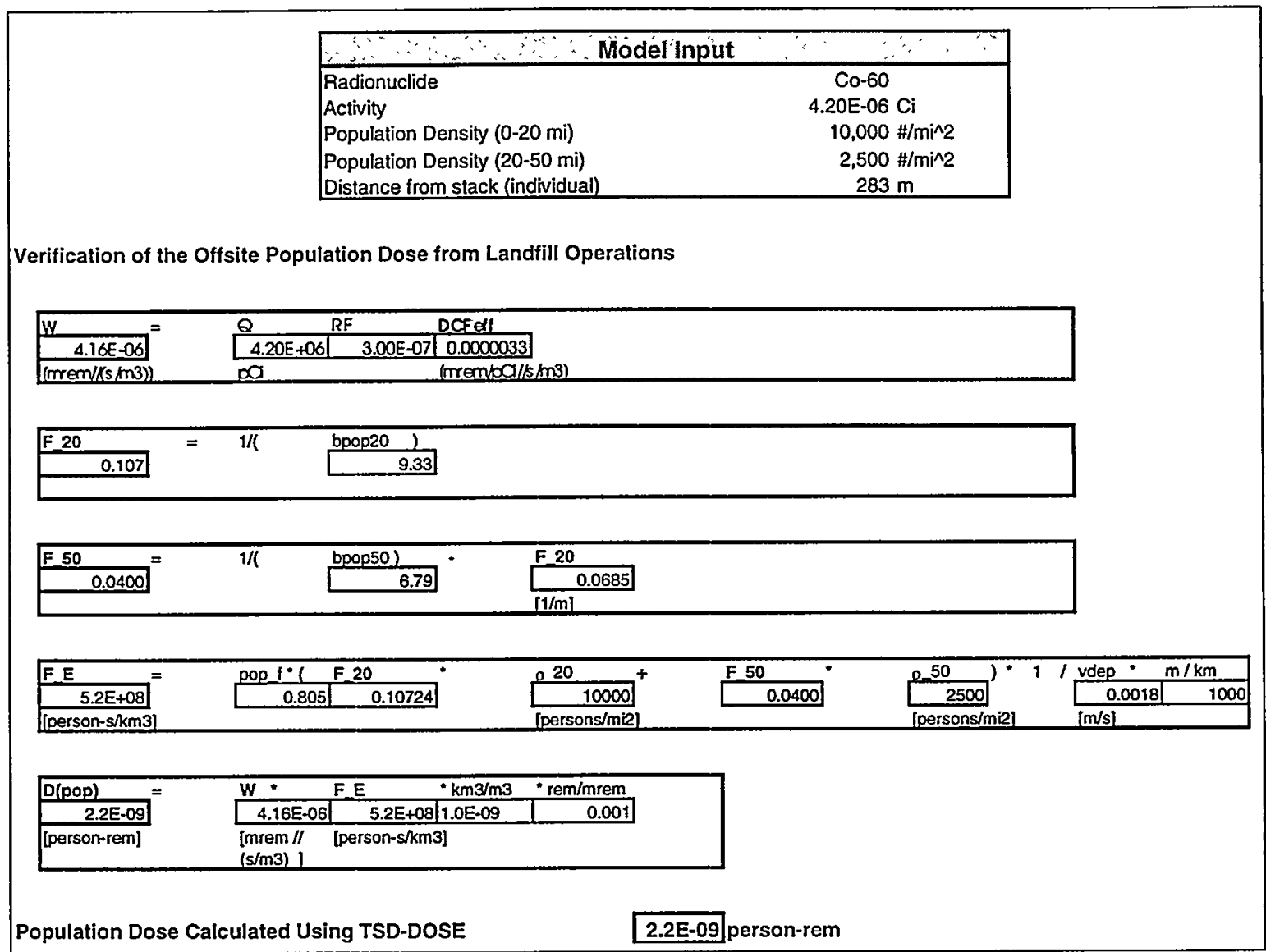

FIGURE 9 Verification of the Off-Site Population Dose from Landfill Operations for Cobalt-60

radionuclides contributing the largest dose to an individual according to TSD-DOSE, e.g., transuranics, the individual and population doses were a factor of 4 and 5, respectively, of CAP88-PC results, with the majority of doses being well within a factor of 2 .

Only one of the TSD facilities was a landfill. For the facility with landfill releases, the TSD-DOSE results were within $20 \%$ for the off-site individual and within $30 \%$ for the general population compared with CAP88-PC results. 
TABLE 9 Comparison of TSD-DOSE Model Predictions with CAP88-PC Calculations for the Individual and General Population for Stack Releases from Incineration and for Landfill Operations

\begin{tabular}{|c|c|c|c|c|c|c|}
\hline \multirow[b]{2}{*}{ Facility } & \multirow[b]{2}{*}{$\begin{array}{l}\text { Release } \\
\text { Type }\end{array}$} & \multirow[b]{2}{*}{$\begin{array}{c}\text { Calculation } \\
\text { Type } \\
\end{array}$} & \multicolumn{2}{|c|}{ Dose to Individual (mrem/yr) } & \multicolumn{2}{|c|}{$\begin{array}{l}\text { Dose to General Population } \\
\text { (person-rem/yr) }\end{array}$} \\
\hline & & & $\begin{array}{c}\text { Average } \\
\text { Release } \\
\end{array}$ & $\begin{array}{c}\text { Maximum } \\
\text { Release }\end{array}$ & $\begin{array}{l}\text { Average } \\
\text { Release }\end{array}$ & $\begin{array}{c}\text { Maximum } \\
\text { Release }\end{array}$ \\
\hline \multirow[t]{2}{*}{ Aptus } & Stack & CAP88-PC & $1.7 \times 10^{-4}$ & $5.0 \times 10^{-4}$ & $4.8 \times 10^{-4}$ & $1.4 \times 10^{-3}$ \\
\hline & & TSD-DOSE & $2.0 \times 10^{-4}$ & $6.0 \times 10^{-4}$ & $4.1 \times 10^{-4}$ & $1.2 \times 10^{-3}$ \\
\hline \multirow[t]{2}{*}{ CWM-Chicago } & Stack & CAP88-PC & $2.6 \times 10^{-4}$ & $1.4 \times 10^{-3}$ & $5.2 \times 10^{-2}$ & $2.8 \times 10^{-1}$ \\
\hline & & TSD-DOSE & $1.7 \times 10^{-4}$ & $9.2 \times 10^{-4}$ & $6.6 \times 10^{-2}$ & $3.6 \times 10^{-1}$ \\
\hline \multirow[t]{2}{*}{ CWM-Emelle } & Landfill & CAP88-PC & $2.0 \times 10^{-8}$ & $1.4 \times 10^{-7}$ & $5.5 \times 10^{-8}$ & $4.0 \times 10^{-7}$ \\
\hline & & TSD-DOSE & $2.4 \times 10^{-8}(\mathrm{a})$ & $1.7 \times 10^{-7}(\mathrm{a})$ & $6.4 \times 10^{-8}$ & $4.6 \times 10^{-7}$ \\
\hline \multirow[t]{2}{*}{ El Dorado } & Stack & CAP88-PC & $5.1 \times 10^{-5}$ & $4.4 \times 10^{-4}$ & $3.4 \times 10^{-4}$ & $2.9 \times 10^{-3}$ \\
\hline & & TSD-DOSE & $4.8 \times 10^{-5}$ & $4.2 \times 10^{-4}$ & $3.1 \times 10^{-4}$ & $2.8 \times 10^{-3}$ \\
\hline \multirow[t]{2}{*}{$\mathrm{LWD}^{\mathrm{b}}$} & Stack & CAP88-PC & $5.6 \times 10^{-3}$ & $5.6 \times 10^{-3}$ & $1.1 \times 10^{-2}$ & $1.1 \times 10^{-2}$ \\
\hline & & TSD-DOSE & $4.7 \times 10^{-3}$ & $4.7 \times 10^{-3}$ & $1.2 \times 10^{-2}$ & $1.2 \times 10^{-2}$ \\
\hline \multirow[t]{2}{*}{ RES } & Stack & CAP88-PC & $1.5 \times 10^{-5}$ & $8.6 \times 10^{-5}$ & $3.3 \times 10^{-3}$ & $1.9 \times 10^{-2}$ \\
\hline & & TSD-DOSE & $1.2 \times 10^{-5}$ & $6.5 \times 10^{-5}$ & $2.7 \times 10^{-3}$ & $1.5 \times 10^{-2}$ \\
\hline
\end{tabular}

a Using the landfill model for individual dose.

$\mathrm{b}$ The dose calculations for the LWD facility were performed for the cumulative release for 2 years. 


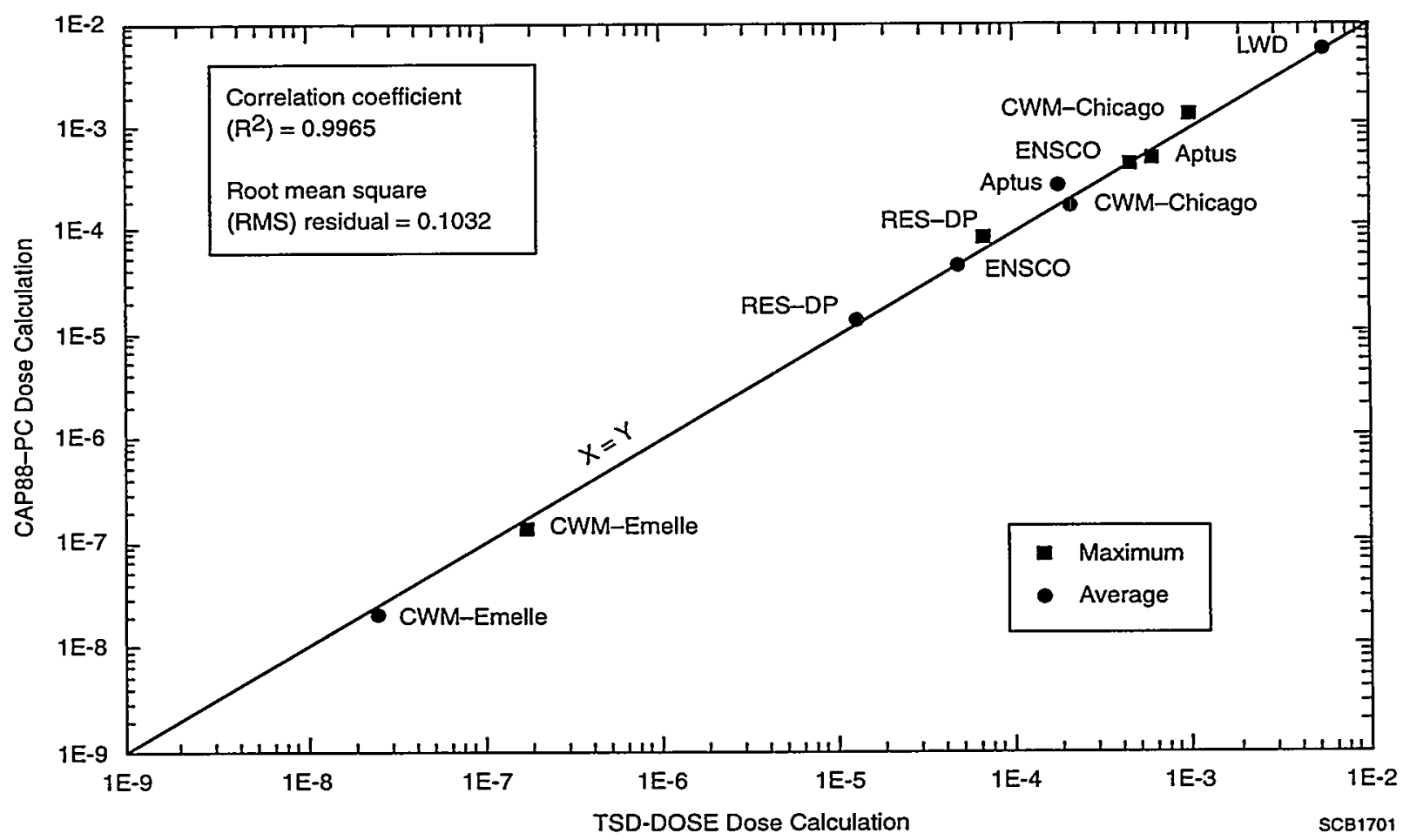

FIGURE 10 Correlation of Off-Site Individual Dose Calculations (mrem/yr): TSD-DOSE versus CAP88-PC (DP = Deer Park, Texas)

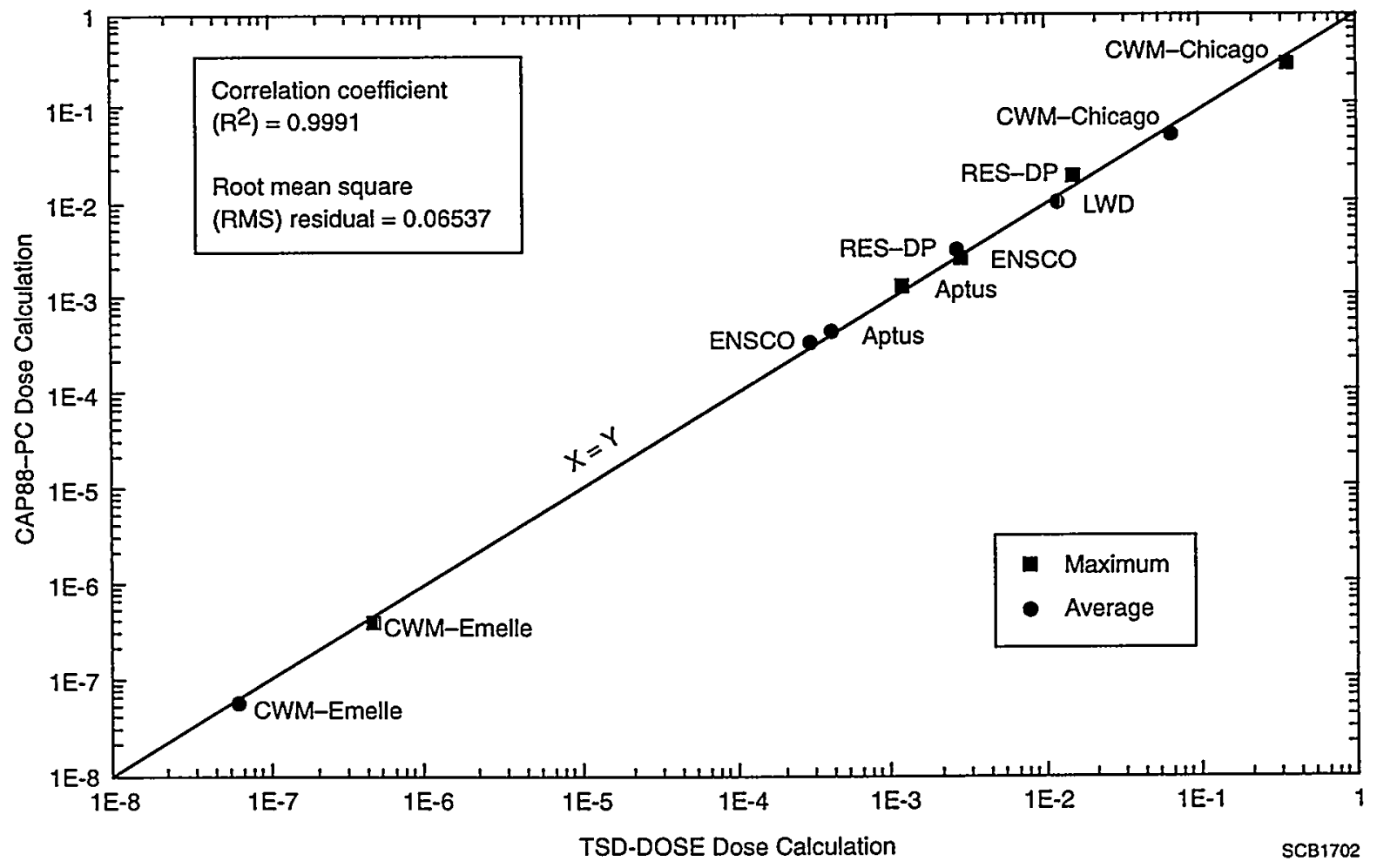

FIGURE 11 Correlation of Off-Site Population Dose Calculations (mrem/yr): TSD-DOSE versus CAP88-PC (DP = Deer Park, Texas) 


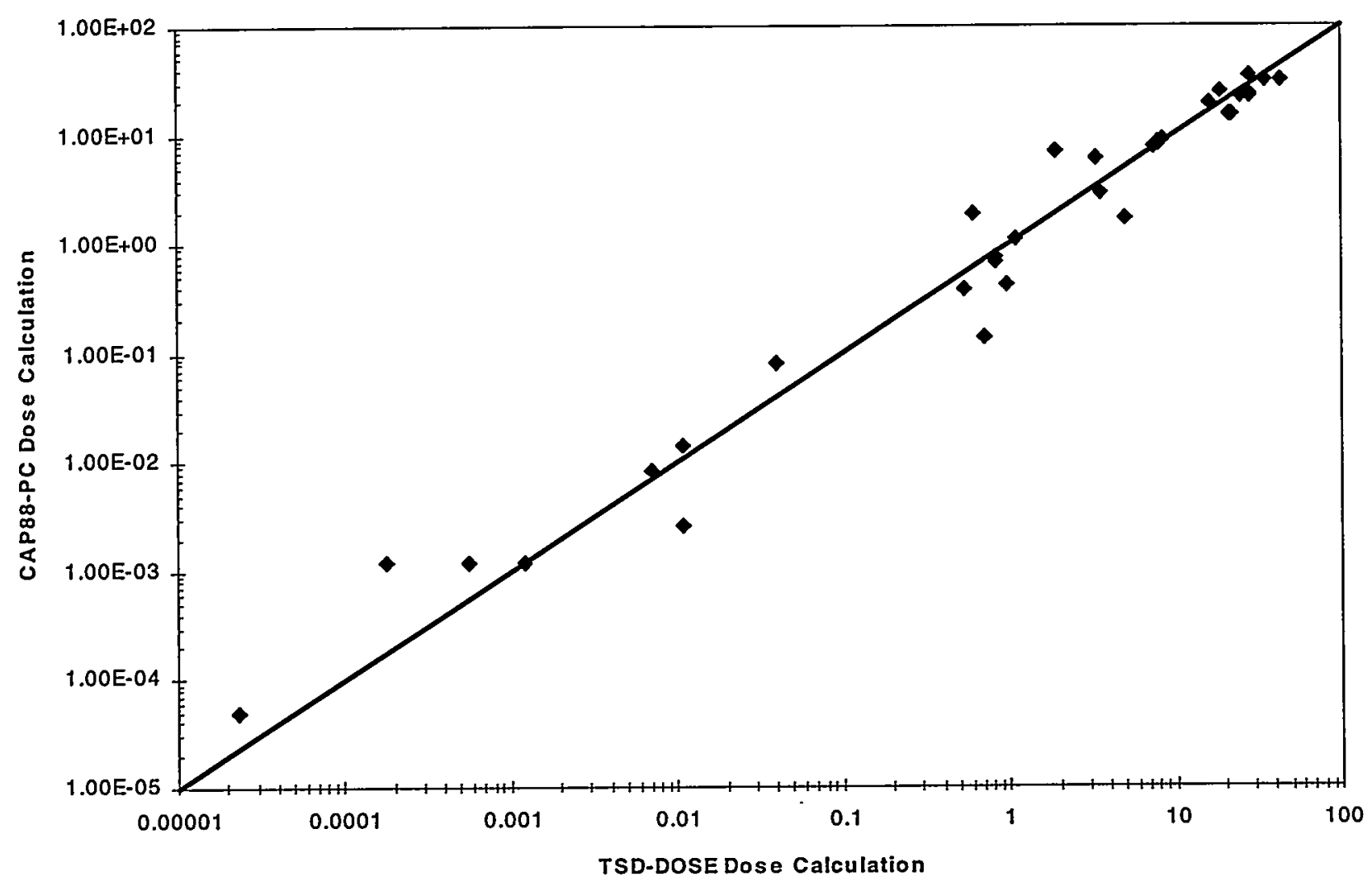

FIGURE 12 CAP88-PC versus TSD-DOSE Individual Dose Benchmarking for All Radionuclides Based on a 1-Ci Release 


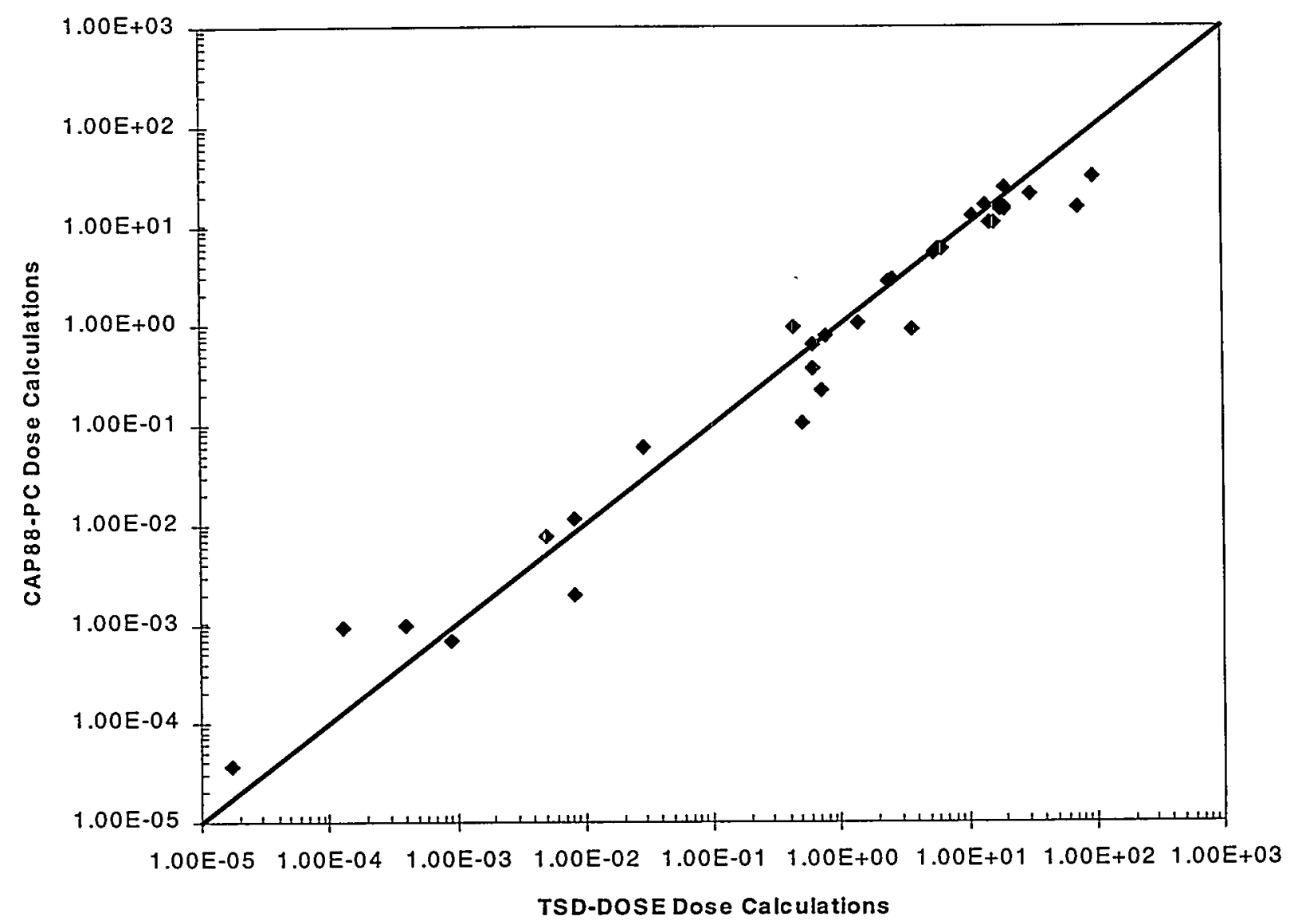

FIGURE 13 CAP88-PC versus TSD-DOSE Population Dose Benchmarking for All Radionuclides Based on a 1-Ci Release 


\section{REFERENCES}

Aaberg, R.L., et al., 1995, Radiation Dose Assessment Methodology and Preliminary Dose Estimates to Support U.S. Department of Energy Radiation Control Criteria for Regulated Treatment and Disposal of Hazardous Wastes and Materials, PNL-9405/UC-610, Pacific Northwest Laboratories, Richland, Wash., July.

Aptus Environmental Services, Inc., 1992, Radiological Dose Assessment of Treatment, Storage, and Disposal of Department of Energy Waste by Aptus Environmental Services, Inc., Coffeyville, Kansas, M.H. Chew \& Associates, Inc., Livermore, Calif., Sept.

Arnish, J.J., 1997, Letter with enclosure from Arnish (Argonne National Laboratory, Argonne, Ill.) to G.A. Vazquez (U.S. Department of Energy, Air, Water, and Radiation Division, Washington, D.C.), June 19.

Briesmeister, J.F. (editor), 1993, MCNP - A General Monte Carlo N-Particle Transport Code, Version 4A, LA-12625, Los Alamos National Laboratory, Los Alamos, N.M.

Chemical Waste Management, Inc., 1993a, Radiological Dose Assessment of Treatment, Storage, and Disposal of Department of Energy Waste by Chemical Waste Management, Inc., Emelle, Alabama, M.H. Chew \& Associates, Inc., Livermore, Calif., July.

Chemical Waste Management, Inc., 1993b, Radiological Dose Assessment of Treatment, Storage, and Disposal of Department of Energy Waste by Chemical Waste Management, Inc., Lake Charles, Louisiana, M.H. Chew \& Associates, Inc., Livermore, Calif., Oct.

Chemical Waste Management, Inc., 1994, Radiological Dose Assessment of Treatment, Storage, and Disposal of Department of Energy Waste by Chemical Waste Management, Inc., Chicago, Illinois, M.H. Chew \& Associates, Inc., Livermore, Calif., Sept.

Chen, S.Y., et al., 1996, "A Waste-Clearance Strategy for DOE Waste Processed at Commercial Facilities," presented at 1996 Annual Meeting of the American Nuclear Society, Reno, Nev., June.

CWM: See Chemical Waste Management, Inc.

DOE: See U.S. Department of Energy. 
Eckerman, K.F., et al., 1988 Limiting Values of Radionuclide Intake and Air Concentration and Dose Conversion Factors for Inhalation, Submersion, and Ingestion, EPA-520/1-88-020, Federal Guidance Report No.11, prepared by Oak Ridge National Laboratory, Oak Ridge, Tenn., for U.S. Environmental Protection Agency, Office of Radiation Programs, Washington, D.C.

Eckerman, K.F., and J.C. Ryman, 1993, External Exposure to Radionuclides in Air, Water, and Soil, Exposure-to-Dose Coefficients for General Application, Based on the 1987 Federal Radiation Protection Guidance, EPA 402-R-93-081, Federal Guidance Report No. 12, prepared by Oak Ridge National Laboratory, Oak Ridge, Tenn., for U.S. Environmental Protection Agency, Office of Radiation and Indoor Air, Washington, D.C.

ENSCO: See Environmental Systems Company, Inc.

Environmental Systems Company, Inc., 1993, Radiological Dose Assessment of Treatment, Storage, and Disposal of Department of Energy Waste by Environmental Systems Company, Inc., El Dorado, Arkansas, M.H. Chew \& Associates, Inc., Livermore, Calif., April.

EPA: See U.S. Environmental Protection Agency.

ICRP: See International Commission on Radiological Protection.

International Commission on Radiological Protection, 1975, "Report of the Task Group on Reference Man," Report 23, in Annals of the ICRP, Pergamon Press, Oxford, U.K.

International Commission on Radiological Protection, 1983, "Radionuclide Transformations: Energy and Intensity of Emissions," ICRP Publication 38, in Annals of the ICRP, Vols. 11-13, Pergamon Press, New York, N.Y.

Kamboj, S., 1998, unpublished information, Argonne National Laboratory, Argonne, Ill.

LWD, Inc., 1993, Radiological Dose Assessment of Treatment, Storage, and Disposal of Department of Energy Waste by LWD, Inc., Calvert City, KY, M.H. Chew \& Associates, Inc., Livermore, Calif., Oct.

National Council on Radiation Protection and Measurements, 1987, Exposure of the Population in the United States and Canada from Natural Background Radiation, NCRP Report No. 94, Bethesda, Md., Dec. 30.

NCRP: See National Council on Radiation Protection and Measurements.

RES: See Rollins Environmental Services, Inc. 
Rollins Environmental Services, Inc., 1994, Radiological Dose Assessment of Treatment, Storage, and Disposal of Department of Energy Waste by Rollins Environmental Services, Inc., Deer Park, Texas, M.H. Chew \& Associates, Inc., Livermore, Calif., Feb.

Schwendiman, L.C., 1977, Supporting Information for the Estimation of Plutonium Oxide Leak Rates through Very Small Apertures, BNWL-2198, Battelle-Pacific Northwest Laboratories, Richland, Wash., Jan.

SDM: See S.D. Myers, Inc.

S.D. Myers, Inc., 1993, Radiological Dose Assessment of Treatment, Storage, and Disposal of Department of Energy Waste by S.D. Myers, Inc., Tallmadge, OH, M.H. Chew \& Associates, Inc., Livermore, Calif., July.

Slade, D., 1968, Meteorology and Atomic Energy 1968, U.S. Department of Commerce, Air Resources Laboratories, Washington, D.C., July.

Stevens, L.E., et al., 1995a, "Issues Related to Estimating Potential Radiological Doses from Treatment, Storage, and Disposal Facilities Handling Waste Containing Trace Amounts of Radioactive Material," presented at Environmental Restoration 1995, Denver, Colo., Aug.

Stevens, L.E., et al., 1995b, "A Simplified Model to Estimate Radiological Doses from Incineration of Radioactive Waste," presented at the 14th International Symposium on Thermal Treatment Technologies: Incineration Conference, Bellevue, Wash., May.

Stevens, L.E., et al., 1996, "Potential Waste Clearance Strategy for U.S. Department of Energy Waste Processed at Treatment, Storage, and Disposal Facilities," presented at WM '96 Conference, Tucson, Ariz., Feb.

Trubey, D.K., 1991, New Gamma-Ray Buildup Factor Data for Point Kernel Calculations: ANS-6.4.3 Standard Reference Data, NUREG-5740, ORNL/RSIC-49, Oak Ridge National Laboratory, Oak Ridge, Tenn., for U.S. Nuclear Regulatory Commission, Washington, D.C., Aug.

U.S. Department of Energy, 1984, Atmospheric Science and Power Production, DOE/TIC-27601, Technical Information Center, Oak Ridge, Tenn., July.

U.S. Environmental Protection Agency, 1989, Air/Superfund National Technical Guidance Study Series, Vol. III - Estimation of Air Emissions from Cleanup Activities at Superfund Site, EPA-450/1-89-003 (interim final report), Office of Air Quality Planning and Standards, Research Triangle Park, N.C. 
U.S. Environmental Protection Agency, 1992, User's Guide for CAP88-PC, Version 1.0, EPA-402-B-92-001, Office of Radiation Programs, Las Vegas, Nev., March.

Yu, C., et al., 1993, Manual for Implementing Residual Radioactive Material Guidelines Using RESRAD, Version 5.0, ANL/EAD/LD-2, Argonne National Laboratory, Argonne, Il.., Sept.

Wang, Y.-Y., et al., 1993, A Compilation of Radionuclide Transfer Factors for the Plant, Meat, Milk, and Aquatic Food Pathways and the Suggested Default Values for the RESRAD Code, ANL/EAIS/TM-103, Argonne National Laboratory, Argonne, $\mathrm{Ml}$.

Westinghouse Idaho Nuclear Company, Inc., 1990, RSAC, Version 4.03: Radiological Safety Analysis Computer Program Interim User's Manual, Idaho Falls, Idaho. 


\section{APPENDIX A:}

\section{PROGRAM INSTRUCTIONS}




\section{APPENDIX A:}

\section{PROGRAM INSTRUCTIONS}

This appendix provides simplified instructions for using the graphical user interface (GUI) for the dose assessment model TSD-DOSE. The GUI simplifies the use of the model by providing a point-and-click interface in a Microsoft Windows ${ }^{\circledR}$ environment. These instructions assume a rudimentary knowledge of Windows. Additional instructions are included in the Help screens accessible throughout the GUI.

\section{A.1 SYSTEM REQUIREMENTS}

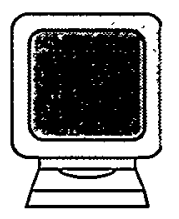

The system requirements are the following:

- Any $\mathrm{IBM}^{\circledR}$-compatible computer (an 80386 processor or higher is recommended),

- At least 4 megabytes of random-access memory (RAM),

- A hard disk with approximately 2 megabytes of available space,

- A 3.5-in. floppy disk drive,

- A mouse or compatible pointing device, and

- Microsoft Windows version 3.0 or later.

\section{A.2 INSTALLATION}

To install the GUI for TSD-DOSE, select file; run from Windows ${ }^{\circledR}$ Program Manager, and type a:lsetup. The setup program will create in Program Manager a new program group called TSD-DOSE. The GUI can be started by clicking the icon within this group. 


\section{A.3 THE GRAPHICAL USER INTERFACE}

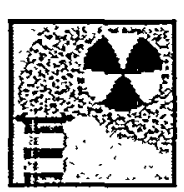

The strategy for using the GUI is given in more detail at the end of this appendix, but in order to better understand the following explanations, the typical strategy involves:

1. Entering the radionuclide inventory for the shipment;

2. Selecting operations applicable to the treatment, storage, and disposal (TSD) facility;

3. Reviewing the resulting bounding dose;

4. Entering site-specific parameters if necessary; and

5. Documenting the results.

When the GUI is executed, the title screen will appear while the program loads and configures itself. Click on the CONTINUE button from the title screen to view the Main Screen shown in Figure A.1. The Main Screen is used to access a variety of windows for inputting radionuclide activities, modifying modeling parameters, entering facility and shipment information, displaying detailed results, accessing Help, opening and saving files, and printing reports. The Main Screen, which is always displayed in the background as other windows are opened, is divided into five areas: the Menu Bar, Functions Toolbar, Operations Icons, Input Window, and Results Window. A program map of the GUI (Figure A.2) shows all of the windows called by the program and how to access them.

\section{A.3.1 Operations Icons}

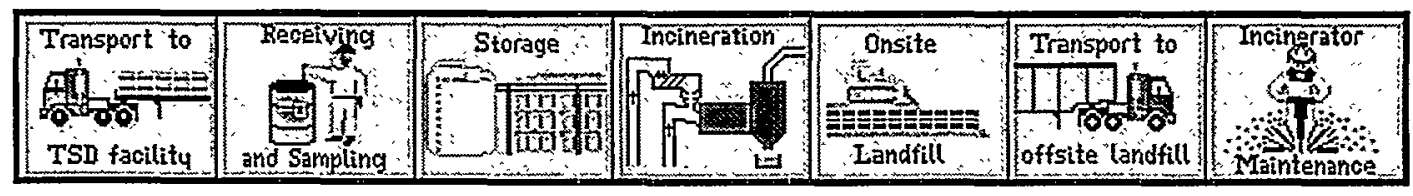

The operations icons are lined up on the left-hand side of the Main Screen. The icons represent the seven operations described in Chapter 2. Clicking the right mouse button on an icon will toggle that operation on or off. If an operation is turned off, the icon is circle-stricken $(\oslash)$, and the dose from that operation is not included in the results. Clicking the left mouse button on an icon will bring up the adjustable parameters screen for that operation (unless the operation is turned off) where site-specific values are needed to model the facility. The adjustable parameters screen for the Transport to TSD Facility operation is shown in Figure A.3. 
Menu Bar

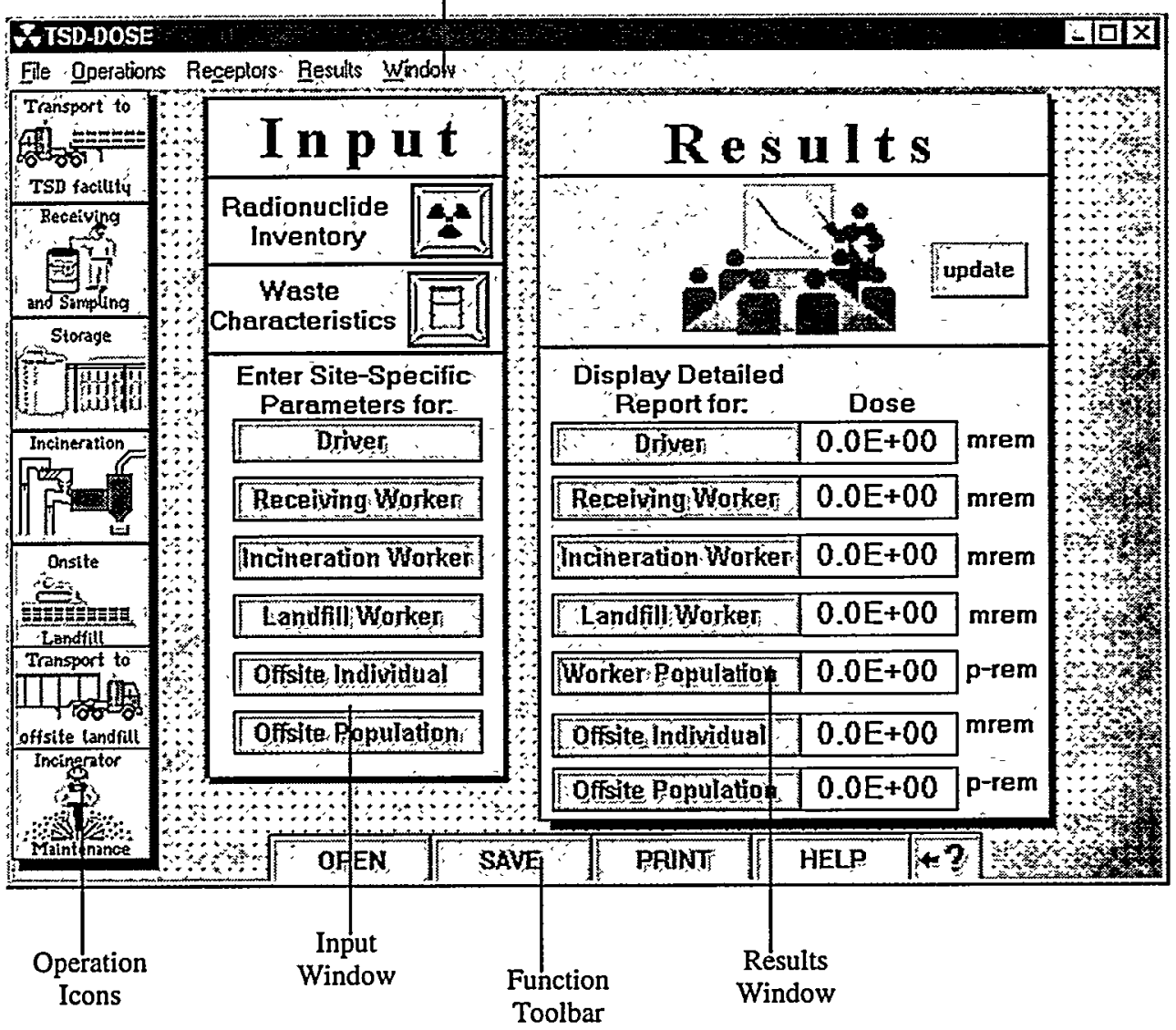

FIGURE A.1 Main Screen of TSD-DOSE

When the GUI is first loaded, the adjustable parameters are set to their default values. To restore a parameter to its default value, click the default button (回) next to it. Changing any of the adjustable parameters will update the doses. When finished entering the adjustable parameters, click CLOSE to return to the Main Screen. For more information on adjustable parameters, see the Help screens associated with each operation (accessing Help screens is discussed in the Functions Toolbar section).

A majority of the adjustable parameters for the model are entered within the adjustable parameters screens for the seven operations; however, some parameters (such as population characteristics) do not fit into any one operation. These parameters are adjusted within the receptor input screens for the off-site individual and the off-site population. For more information on these parameters, see Section A.3.2. 


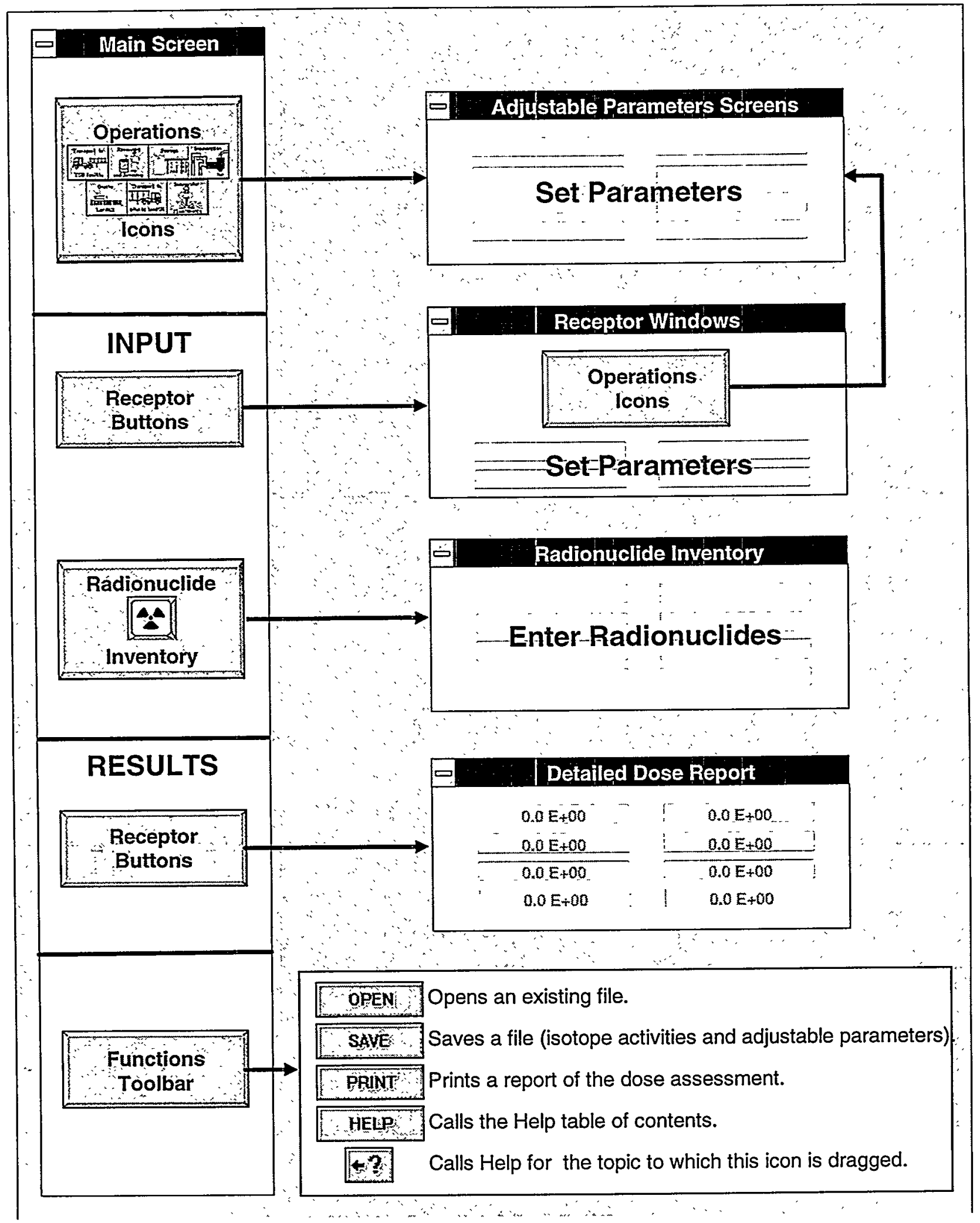

FIGURE A.2 Program Map of the GUI 


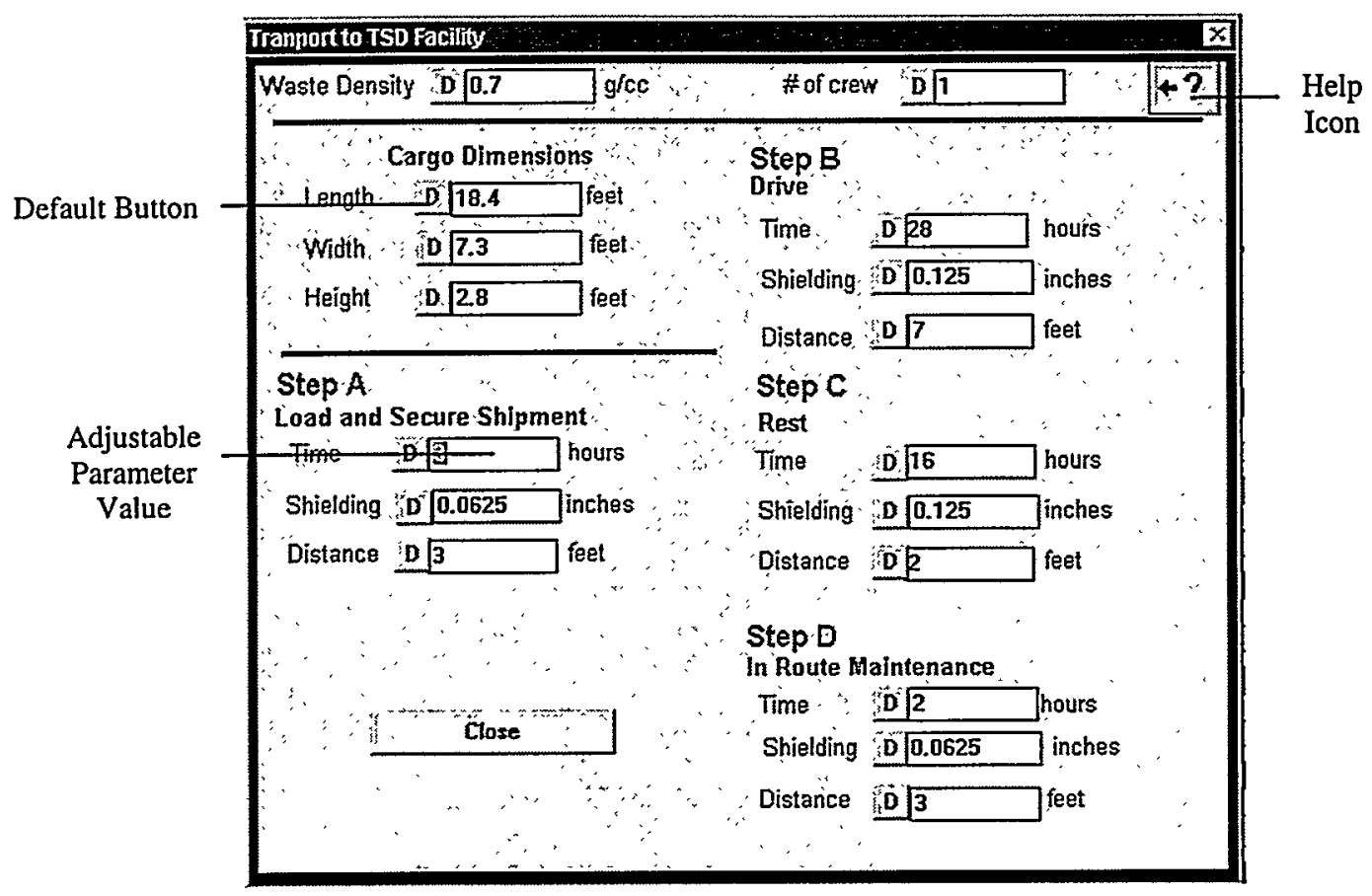

FIGURE A.3 Adjustable Parameters Screen for Transport to TSD Facility

\section{A.3.2 Input Window}

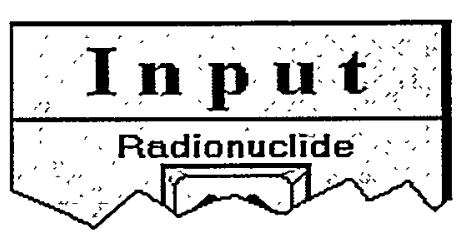

The Input Window is used to enter radionuclide activities and is an alternative way to access the adjustable parameters screens. Clicking the Radionuclide Inventory button brings up the window to enter the radionuclide activities. Proceed by selecting a radionuclide from the pull-down list at the bottom of the screen, entering its activity in the text box, and clicking on the ADD button. To delete a radionuclide or change its activity, click on the appropriate radionuclide in the large text box. The radionuclide will be removed from the large text box and returned to the pull-down list. Click on the ADD button to return the radionuclide to the list of included radionuclides after changes have been made. When finished entering the entire inventory, click on the CLOSE button to return to the Main Screen.

Clicking one of the receptor buttons in the Input Window will show a window with the icon and the dose for each of the operations that affect that receptor. Clicking on the Operation Icons within these windows will bring up the appropriate adjustable parameters screen.

Offsite Individual and Offsite Population Windows also contain adjustable parameters for these receptors. Changes are reflected in the results as new parameters are entered. 


\section{A.3.3 Results Window}

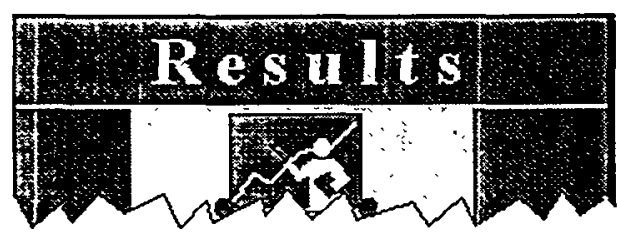

The Results Window continuously displays the total dose to each receptor. Clicking the receptor buttons in the Results Window will bring up detailed dose reports that show the breakdown of the dose by operation and type of dose incurred (i.e., internal or external). Additional Results Windows can be accessed through the Menu Bar.

\section{A.3.4 Functions Toolbar}

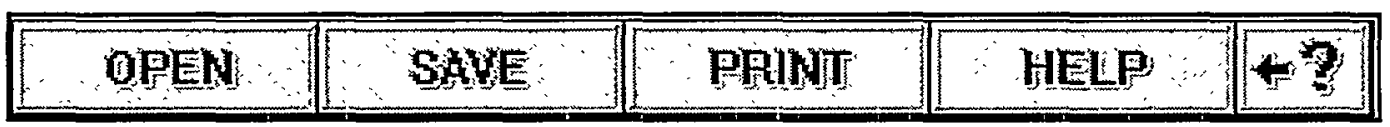

The Functions Toolbar is used to activate commonly used functions, such as opening and saving documents, printing reports, and accessing Help. Clicking on the OPEN button will bring up the Open File window that displays the current directory and all of the saved dose assessment model files $(*$.WCS $)$ contained in that directory.

Clicking on the SAVE button will first display the General Information Window. Before saving a file, the TSD facility, the program user, and the shipment description must be entered. After this entry process is done, clicking on the SAVE button will bring up the Save File window, which allows the user to browse the directories and enter an eight-character file name before saving (the extension ".WCS" is automatically added to the file name). A file stores all isotope activities and facility parameters.

Click on the PRINT button to first bring up the General Information Window before printing a report. The report lists the doses to each receptor, as well as a breakdown by isotope, and the adjustable parameters used in the dose calculations.

The HELP button and the $\leftarrow$ ? button are used to access the Help screens. Click on the HELP button to open the table of contents for the Help screens. Help on a specific topic can be called up via the table of contents, by clicking the SEARCH button within the Help window, or by holding down the mouse button over the $\leftarrow$ ? button and then dragging the icon to the specific area of interest on the screen. The $\leftarrow$ ? button also appears on each of the adjustable parameters screens.

\section{A.3.5 Menu Bar}

The Menu Bar shown in Figure A.4 can be used to perform most of the functions described up to this point. Additional features include dose breakdown by isotope for each receptor and logarithmic bar graphs of the doses to receptors or the doses caused by each operation. 


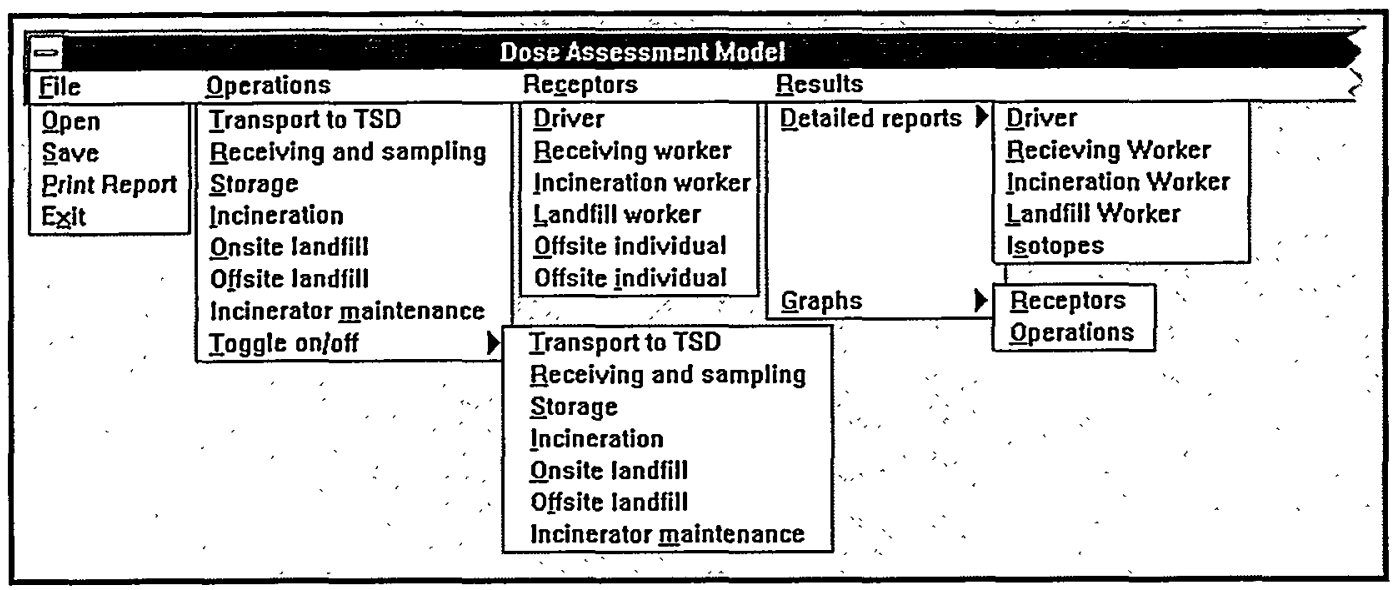

FIGURE A.4 The Menu Bar

\section{A.4 USING THE GRAPHICAL USER INTERFACE}

The model is intended to be used in an iterative fashion, as depicted in Figure A.5. The first step is to enter the radionuclide activities and turn on or off the operations icons at the left side of the screen to match the TSD facility being assessed. This step will give a bounding dose for the shipment. Site-specific values for the adjustable parameters can then be entered as necessary to refine the dose calculation and to make the calculated dose more accurate for the specific site.

During the iterative process of entering site-specific values, the calculated doses need to be compared against some criteria. Currently, acceptable criteria are not clearly defined, although some states do have in place dose limits to members of the public. International organizations such as the International Atomic Energy Agency are working to develop public dose limits, and the U.S. Department of Energy is considering developing clearance criteria. If no dose limits are available, then the results of the dose calculations need to be evaluated on a case-by-case basis in order to judge acceptability. This judgment should be made in the context of the regulatory environment at the facility. The doses calculated with the model must be acceptable to regulatory agencies. In some cases, the user may wish to input all available sitespecific parameters, regardless of the magnitude of the calculated dose, in order to increase confidence in the results of the model.

The receptor windows are helpful in deciding which site-specific parameters to enter if the iterative process is used. Click on the Receptor button in the Input Window corresponding to the receptor receiving the highest dose, and then click on the operation in the Receptor Window that contributes the highest dose, or adjust the off-site individual or population parameters. This method is meant only to save the user time in identifying which site-specific parameters to evaluate. The user must be careful to employ a certain degree of conservatism when entering site-specific parameters that cannot be determined exactly, such as durations and distances. Once acceptable doses have been calculated, save the file and print a dose assessment report. 


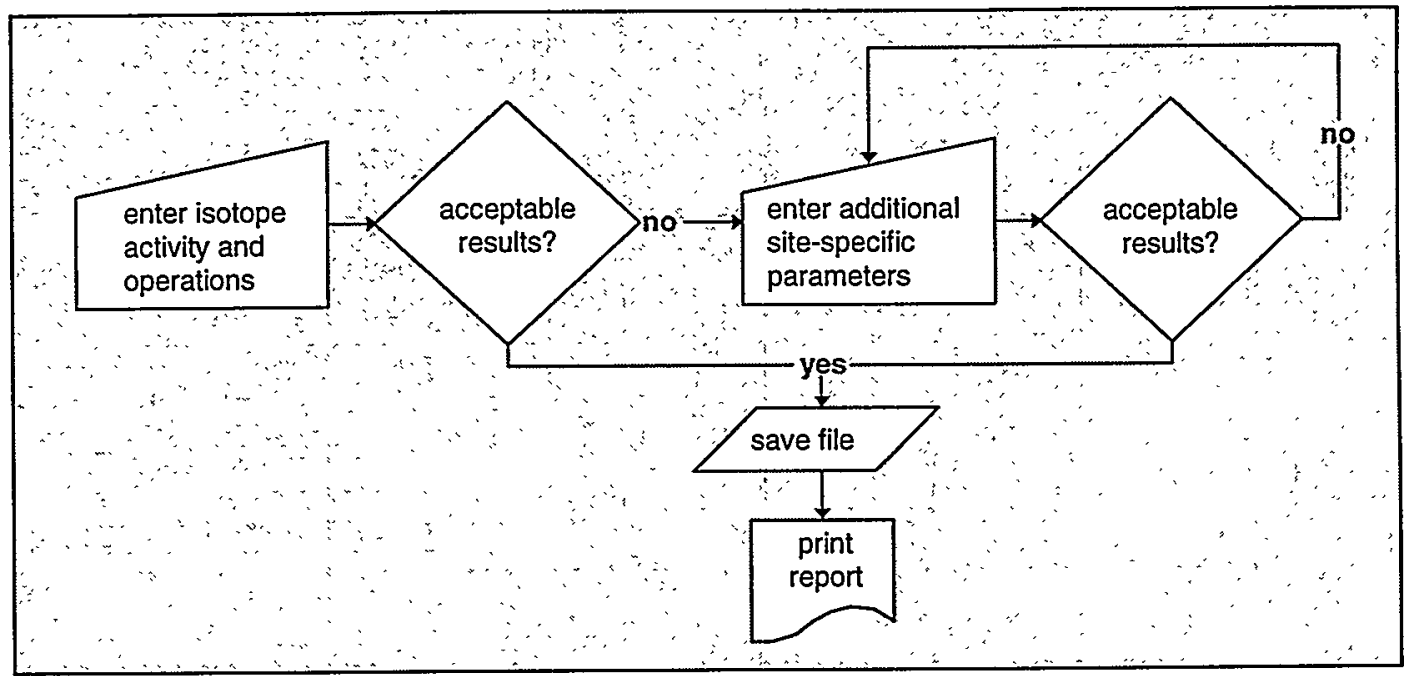

FIGURE A.5 Flowchart for GUI Usage 


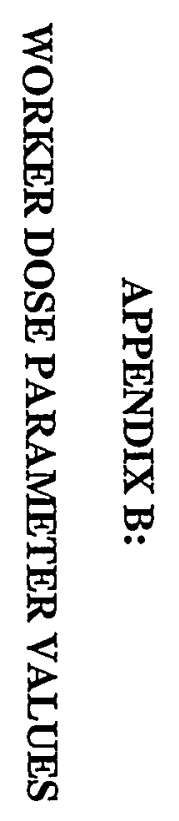


B-2 


\section{APPENDIX B:}

\section{WORKER DOSE PARAMETER VALUES}

This appendix provides some of the raw data used in the dose calculations for the treatment, storage, and disposal (TSD) facility worker. Table B.1 shows the ranges for the parameters from the eight previously assessed TSD facilities. Tables B.2 and B.3 show the default values used in the calculations for internal and external doses in TSD-DOSE. 
TABLE B.1 Parameter Ranges Based on Eight Previously Assessed TSD Facilities

\begin{tabular}{|c|c|c|c|c|c|c|}
\hline Operation & Step $^{\mathrm{a}}$ & $\mathrm{Hi} / \mathrm{Low}$ & $\begin{array}{c}\text { Source } \\
\text { Geometry }\end{array}$ & $\begin{array}{c}\text { Shielding } \\
\text { Thickness (in.) }\end{array}$ & Duration & Distance $(\mathrm{ft})$ \\
\hline \multirow{8}{*}{$\begin{array}{l}\text { 1: Transport } \\
\text { to TSD } \\
\text { facility }\end{array}$} & \multirow[t]{2}{*}{ A } & Low & 40 drums & 0.063 & $0.5 \mathrm{~h}$ & 5 \\
\hline & & High & 80 drums & 0.38 & $1 \mathrm{~h}$ & 10 \\
\hline & \multirow[t]{2}{*}{ B } & Low & 40 drums & 0.125 & $8 \mathrm{~h}$ & 5 \\
\hline & & High & 80 drums & 0.38 & $28 \mathrm{~h}$ & 10 \\
\hline & \multirow[t]{2}{*}{ C } & Low & 40 drums & 0.125 & $\mathrm{Oh}$ & 5 \\
\hline & & High & 80 drums & 0.38 & $8 \mathrm{~h}$ & 5 \\
\hline & \multirow[t]{2}{*}{$\mathrm{D}$} & Low & 40 drums & 0.063 & $0.5 \mathrm{~h}$ & 5 \\
\hline & & High & 80 drums & 0.38 & $1 \mathrm{~h}$ & 10 \\
\hline \multirow{10}{*}{$\begin{array}{l}\text { 2: Receiving } \\
\text { and sampling }\end{array}$} & \multirow[t]{2}{*}{ A } & Low & 40 drums & 0.063 & $0.5 \mathrm{~h} / \mathrm{truck}$ & 5 \\
\hline & & High & 80 drums & 0.31 & $5 \mathrm{~h}$ & 10 \\
\hline & \multirow[t]{2}{*}{ B } & Low & 20-gal drum & 0.063 & $1 \mathrm{~min} /$ pallet & 0.3 \\
\hline & & High & 55-gal drum & 0.31 & $2 \mathrm{~h} / \mathrm{truck}$ & 5 \\
\hline & \multirow[t]{2}{*}{$\mathrm{C}$} & Low & 20-gal drum & 0.063 & $1 \mathrm{~h} /$ truck & 0.3 \\
\hline & & High & 55-gal drum & 0.31 & $5 \mathrm{~min} / \mathrm{drum}$ & 0.5 \\
\hline & \multirow[t]{2}{*}{ D } & Low & 20-gal drum & 0.063 & $1 \mathrm{~min} /$ pallet & 5 \\
\hline & & High & 55-gal drum & 0.31 & $1 \mathrm{~h} /$ truck & 5 \\
\hline & \multirow[t]{2}{*}{ E } & Low & 20-gal drum & 0.063 & $2 \mathrm{~min} / \mathrm{drum}$ & 0.3 \\
\hline & & High & 55-gal drum & 0.31 & $5 \mathrm{~min} / \mathrm{drum}$ & 5 \\
\hline \multirow[t]{6}{*}{ 3: Storage } & \multirow[t]{2}{*}{ A } & Low & 40 drums & 0.063 & $30 \times 1 \mathrm{~h}$ & 5 \\
\hline & & High & 96 drums & 0.063 & $250 \times 0.5 \mathrm{~h}$ & 10 \\
\hline & \multirow[t]{2}{*}{ B } & Low & 20-gal drum & 0.063 & $1 \mathrm{~min} /$ pallet & 0.3 \\
\hline & & High & 55-gal drum & 0.063 & $5 \mathrm{~min} / \mathrm{pallet}$ & 5 \\
\hline & \multirow[t]{2}{*}{ C } & Low & $24 \mathrm{ft} \mathrm{H} \times 5.3 \mathrm{ft} \mathrm{R}^{\mathrm{b}}$ & 0.188 & $3 \times 0.5 \mathrm{~h}$ & 5 \\
\hline & & High & $32 \mathrm{ft} \mathrm{H} \times 36 \mathrm{ft} \mathrm{R}$ & 0.5 & $250 \times 1 \mathrm{~h}$ & 20 \\
\hline \multirow[t]{7}{*}{ 4: Incineration } & A & $-c$ & $-c$ & $-c$ & $-^{c}$ & $-^{c}$ \\
\hline & \multirow[t]{2}{*}{ B } & Low & $3 \mathrm{ft} \times 3 \mathrm{ft} \times 3 \mathrm{ft}$ & 0.13 & $2 \min$ & 0.3 \\
\hline & & High & $30 \mathrm{ft} \times 7 \mathrm{ft} \times 5 \mathrm{ft}$ & 0.5 & $0.5 \mathrm{~h}$ & 5 \\
\hline & \multirow[t]{2}{*}{$\mathrm{C}$} & Low & $7 \mathrm{ft} \times 4 \mathrm{ft} \times 4 \mathrm{ft}$ & 0.25 & $10 \mathrm{~min}$ & 3 \\
\hline & & High & $30 \mathrm{ft} \times 7 \mathrm{ft} \times 5 \mathrm{ft}$ & 0.5 & $6 \mathrm{~h}$ & 5 \\
\hline & \multirow[t]{2}{*}{$\mathrm{D}$} & Low & $7 \mathrm{ft} \times 4 \mathrm{ft} \times 4 \mathrm{ft}$ & 0.2 & $7 \mathrm{~min}$ & 5 \\
\hline & & High & $20 \mathrm{ft} \times 8 \mathrm{ft} \times 4 \mathrm{ft}$ & 0.5 & $20 \mathrm{~min}$ & 20 \\
\hline \multirow{8}{*}{$\begin{array}{l}\text { 5: On-site } \\
\text { landfill }\end{array}$} & A & Low & $30 \mathrm{ft} \times 7 \mathrm{ft} \times 5 \mathrm{ft}$ & 0.5 & $5 \mathrm{~min}$ & 5 \\
\hline & & High & $30 \mathrm{ft} \times 7 \mathrm{ft} \times 5 \mathrm{ft}$ & 0.5 & $10 \mathrm{~min}$ & 10 \\
\hline & B & Low & 1 drum & 0.063 & $0.33 \mathrm{~h}$ & 0.3 \\
\hline & & High & $20 \mathrm{ft} \times 10 \mathrm{ft} \times 10 \mathrm{ft}$ & Soil & $1 \mathrm{~h}$ & 20 \\
\hline & $\mathrm{C}$ & Low & $25 \mathrm{ft} \times 7 \mathrm{ft} \times 4.5 \mathrm{ft}$ & 0.18 & $10 \mathrm{~min}$ & 5 \\
\hline & & High & $30 \mathrm{ft} \times 7 \mathrm{ft} \times 5 \mathrm{ft}$ & 0.5 & $35 \mathrm{~min}$ & 20 \\
\hline & $\mathrm{D}$ & Low & 2 drums & 0.063 & $8 \mathrm{~min}$ & 5 \\
\hline & & High & $30 \mathrm{ft} \times 7 \mathrm{ft} \times 5 \mathrm{ft}$ & 0.5 & $35 \mathrm{~min}$ & 20 \\
\hline 6: Transport & $\mathrm{A}$ & Low & $20 \mathrm{ft} \times 7 \mathrm{ft} \times 4 \mathrm{ft}$ & 0.25 & $0.5 \mathrm{~h}$ & 5 \\
\hline to on-site & & High & $30 \mathrm{ft} \times 7 \mathrm{ft} \times 5 \mathrm{ft}$ & 0.5 & $2 \mathrm{~h}$ & 10 \\
\hline landfill & $\mathrm{B}$ & Low & $20 \mathrm{ft} \times 7 \mathrm{ft} \times 4 \mathrm{ft}$ & 0.25 & $3 \mathrm{~h}$ & 5 \\
\hline & & High & $30 \mathrm{ft} \times 7 \mathrm{ft} \times 5 \mathrm{ft}$ & 0.5 & $20 \mathrm{~h}$ & 10 \\
\hline & $\mathrm{C}$ & Low & $20 \mathrm{ft} \times 7 \mathrm{ft} \times 4 \mathrm{ft}$ & 0.25 & $\mathrm{Oh}$ & 5 \\
\hline & & High & $30 \mathrm{ft} \times 7 \mathrm{ft} \times 5 \mathrm{ft}$ & 0.5 & $8 \mathrm{~h}$ & 5 \\
\hline & $\mathrm{D}$ & Low & $20 \mathrm{ft} \times 7 \mathrm{ft} \times 4 \mathrm{ft}$ & 0.25 & $0.3 \mathrm{~h}$ & 5 \\
\hline & & High & $30 \mathrm{ft} \times 7 \mathrm{ft} \times 5 \mathrm{ft}$ & 0.5 & $1 \mathrm{~h}$ & 10 \\
\hline 7: Incinerator & $\mathrm{A}$ & Low & $6.5 \mathrm{ft} \mathrm{R} \times 40 \mathrm{ft} \mathrm{H}$ & $-d$ & $18 \mathrm{~h}$ & 0.5 \\
\hline maintenance & & High & $92 \mathrm{ft} \mathrm{H} \times 12 \mathrm{ft} \mathrm{R}$ & $-^{\mathrm{d}}$ & $24 \mathrm{~h}$ & 3 \\
\hline a See Section 2 & the $m$, t & renort $f(x)$ & deccrintion of the & & No external & \\
\hline b $\mathrm{H}=$ height; $\mathrm{R}$ & adius. & & & & Not applicabl & \\
\hline
\end{tabular}


TABLE B.2 External Dose Default Parameter Values ${ }^{a, b}$

\begin{tabular}{|c|c|c|c|c|c|c|}
\hline Operation & Step & $\begin{array}{c}\text { Source } \\
\text { Geometry }\end{array}$ & $\begin{array}{l}\text { Shielding } \\
\text { Thickness }\end{array}$ & Duration & Distance & Notes \\
\hline \multirow{4}{*}{$\begin{array}{l}\text { 1: Transport } \\
\text { to TSD } \\
\text { facility }\end{array}$} & A & $18.4 \mathrm{ft} \times 7.3 \mathrm{ft} \times 2.8 \mathrm{ft}$ & $0.063 \mathrm{in}$ & $3 \mathrm{~h}$ & $3 \mathrm{ft}$ & \\
\hline & $\mathrm{B}$ & $18.4 \mathrm{ft} \times 7.3 \mathrm{ft} \times 2.8 \mathrm{ft}$ & $0.125 \mathrm{in}$. & $28 \mathrm{~h}$ & $7 \mathrm{ft}$ & \\
\hline & $\mathrm{C}$ & $18.4 \mathrm{ft} \times 7.3 \mathrm{ft} \times 2.8 \mathrm{ft}$ & $0.125 \mathrm{in}$. & $16 \mathrm{~h}$ & $2 \mathrm{ft}$ & \\
\hline & $\mathrm{D}$ & $18.4 \mathrm{ft} \times 7.3 \mathrm{ft} \times 2.8 \mathrm{ft}$ & 0.063 in. & $2 \mathrm{~h}$ & $3 \mathrm{ft}$ & \\
\hline \multirow{5}{*}{$\begin{array}{l}\text { 2: Receiving } \\
\text { and sampling }\end{array}$} & $A$ & $18.4 \mathrm{ft} \times 7.3 \mathrm{ft} \times 2.8 \mathrm{ft}$ & 0.063 in. & $1 \mathrm{~h}$ & $5 \mathrm{ft}$ & \\
\hline & $\mathrm{B}$ & $1.6 \mathrm{ft} \times 1.6 \mathrm{ft} \times 2.8 \mathrm{ft}$ & $0.063 \mathrm{in.}$ & $0.083 \mathrm{~h}$ & $3 \mathrm{ft}$ & \\
\hline & $\mathrm{C}$ & $1.6 \mathrm{ft} \times 1.6 \mathrm{ft} \times 2.8 \mathrm{ft}$ & $0.063 \mathrm{in.}$ & $0.083 \mathrm{~h}$ & $0.5 \mathrm{ft}$ & See internal dose parameters. \\
\hline & $\mathrm{D}$ & $1.6 \mathrm{ft} \times 1.6 \mathrm{ft} \times 2.8 \mathrm{ft}$ & $0.063 \mathrm{in.}$ & $0.167 \mathrm{~h}$ & $3 \mathrm{ft}$ & \\
\hline & $E$ & $1.6 \mathrm{ft} \times 1.6 \mathrm{ft} \times 2.8 \mathrm{ft}$ & 0.063 in. & $0.0833 \mathrm{~h}$ & $0.5 \mathrm{ft}$ & \\
\hline \multirow[t]{3}{*}{ 3: Storage } & $A$ & $18.4 \mathrm{ft} \times 7.3 \mathrm{ft} \times 2.8 \mathrm{ft}$ & $0.063 \mathrm{in}$. & $60 \mathrm{~h}$ & $3 \mathrm{ft}$ & \\
\hline & B & $1.6 \mathrm{ft} \times 1.6 \mathrm{ft} \times 2.8 \mathrm{ft}$ & $0.063 \mathrm{in}$ & $0.083 \mathrm{~h}$ & $3 \mathrm{ft}$ & \\
\hline & $\mathrm{C}$ & $7 \mathrm{ft} \times 7 \mathrm{ft} \times 12 \mathrm{ft}$ & $0.125 \mathrm{in}$. & $60 \mathrm{~h}$ & $3 \mathrm{ft}$ & \\
\hline \multirow[t]{4}{*}{ 4: Incineration } & $\mathrm{A}$ & $-c$ & $-c$ & $-c$ & $-c$ & See internal dose parameters. \\
\hline & $\mathrm{B}$ & $5 \mathrm{ft} \times 3 \mathrm{ft} \times 3 \mathrm{ft}$ & $0.125 \mathrm{in}$. & $0.25 \mathrm{~h}$ & $2 \mathrm{ft}$ & \\
\hline & $\mathrm{C}$ & $5 \mathrm{ft} \times 3 \mathrm{ft} \times 3 \mathrm{ft}$ & $0.125 \mathrm{in}$. & $0.25 \mathrm{~h}$ & $2 \mathrm{ft}$ & \\
\hline & $\mathrm{D}$ & $5 \mathrm{ft} \times 3 \mathrm{ft} \times 3 \mathrm{ft}$ & $0.125 \mathrm{in}$ & $0.25 \mathrm{~h}$ & $2 \mathrm{ft}$ & \\
\hline \multirow{4}{*}{$\begin{array}{l}\text { 5: On-site } \\
\text { landfill }\end{array}$} & $\mathrm{A}$ & $25 \mathrm{ft} \times 6 \mathrm{ft} \times 3 \mathrm{ft}$ & $0.125 \mathrm{in}$. & $0.25 \mathrm{~h}$ & $5 \mathrm{ft}$ & See internal dose parameter \\
\hline & $\mathrm{B}$ & $10 \mathrm{ft} \times 10 \mathrm{ft} \times 10 \mathrm{ft}$ & N/A & $0.5 \mathrm{~h}$ & $10 \mathrm{ft}$ & $\begin{array}{l}\text { Partially shielded by earth } \\
\text { between pit and receptor. }\end{array}$ \\
\hline & $\mathrm{C}$ & $25 \mathrm{ft} \times 6 \mathrm{ft} \times 3 \mathrm{ft}$ & $0.125 \mathrm{in}$. & $0.25 \mathrm{~h}$ & $5 \mathrm{ft}$ & \\
\hline & $\mathrm{D}$ & $25 \mathrm{ft} \times 6 \mathrm{ft} \times 3 \mathrm{ft}$ & 0.125 in. & $0.25 \mathrm{~h}$ & $5 \mathrm{ft}$ & \\
\hline \multirow{4}{*}{$\begin{array}{l}\text { 6: Transport } \\
\text { to on-site } \\
\text { landfill }\end{array}$} & $\bar{A}$ & $25 \mathrm{ft} \times 6 \mathrm{ft} \times 3 \mathrm{ft}$ & $0.125 \mathrm{in}$. & $3 \mathrm{~h}$ & $3 \mathrm{ft}$ & \\
\hline & $\mathrm{B}$ & $25 \mathrm{ft} \times 6 \mathrm{ft} \times 3 \mathrm{ft}$ & $0.125 \mathrm{in}$. & $28 \mathrm{~h}$ & $7 \mathrm{ft}$ & \\
\hline & $\mathrm{C}$ & $25 \mathrm{ft} \times 6 \mathrm{ft} \times 3 \mathrm{ft}$ & $0.125 \mathrm{in}$. & $16 \mathrm{~h}$ & $2 \mathrm{ft}$ & \\
\hline & D & $25 \mathrm{ft} \times 6 \mathrm{ft} \times 3 \mathrm{ft}$ & $0.125 \mathrm{in}$ & $2 \mathrm{~h}$ & $3 \mathrm{ft}$ & \\
\hline Operation & Step & $\begin{array}{c}\text { Source } \\
\text { Geometry } \\
\end{array}$ & Liquids (lb) & Solids (lb) & Duration & Distance \\
\hline $\begin{array}{l}\text { 7: Incinerator } \\
\text { maintenance }\end{array}$ & $A$ & $100 \mathrm{ft} \times 8 \mathrm{ft} \times 0.5 \mathrm{ft}$ & $25,000,000$ & $25,000,000$ & $12 \mathrm{~h}$ & $3 \mathrm{ft}$ \\
\hline
\end{tabular}

a $\mathrm{H}=$ height; $\mathrm{L}=$ length; $\mathrm{N} / \mathrm{A}=$ not applicable (times are linearly proportional; therefore base doses are not required); NAP = not an adjustable parameter; and $\mathrm{R}=$ radius.

\begin{tabular}{|c|c|}
\hline $\begin{array}{c}\text { Preprocessed Waste Density } \\
\text { (Operations 1-3) }\end{array}$ & $\begin{array}{c}\text { Processed Waste Density } \\
\text { (Operations 4-6) }\end{array}$ \\
\hline $0.7 \mathrm{~g} / \mathrm{cm}^{3}$ & $1.4 \mathrm{~g} / \mathrm{cm}^{3}$ \\
\hline
\end{tabular}

c No external dose. 
TABLE B.3 Internal Dose Default Parameter Values

\begin{tabular}{|c|c|c|c|}
\hline Parameter & Value & Parameter & Value \\
\hline $\begin{array}{l}\text { Step } 2 \mathrm{C} \\
\text { Airborne respirable dust concentration } \\
\text { Respiratory protection factor }\end{array}$ & $\begin{array}{c}10 \mathrm{mg} / \mathrm{m}^{3} \\
10\end{array}$ & $\begin{array}{l}\text { Step 5A } \\
\text { Airborne respirable dust concentration } \\
\text { Respiratory protection factor }\end{array}$ & $\begin{array}{c}1 \mathrm{mg} / \mathrm{m}^{3} \\
1\end{array}$ \\
\hline $\begin{array}{l}\text { Step } 4 \mathrm{~A} \\
\text { Stack height } \\
\text { Wind speed } \\
\text { Exit velocity } \\
\text { Stack diameter } \\
\text { Surrounding building height } \\
\end{array}$ & $\begin{array}{c}60 \mathrm{ft} \\
3 \mathrm{mph} \\
9 \mathrm{mph} \\
9 \mathrm{ft} \\
60 \mathrm{ft} \\
\end{array}$ & $\begin{array}{l}\text { Step 7A } \\
\text { Airborne respirable dust concentration } \\
\text { Respiratory protection factor }\end{array}$ & $\begin{array}{c}10 \mathrm{mg} / \mathrm{m}^{3} \\
50\end{array}$ \\
\hline Isotope & $\begin{array}{c}\text { Release } \\
\text { Fraction }^{\mathrm{a}}\end{array}$ & Isotope & $\begin{array}{c}\text { Release } \\
\text { Fraction }^{\mathrm{a}}\end{array}$ \\
\hline$A c-227+D$ & $5.00 \mathrm{E}-04$ & $\mathrm{Ni}-63$ & $5.00 \mathrm{E}-03$ \\
\hline$A g-108+D$ & $1.00 \mathrm{E}-03$ & Np-237+D & $5.00 \mathrm{E}-04$ \\
\hline $\mathrm{Ag}-100 \mathrm{~m}+\mathrm{D}$ & $1.00 \mathrm{E}-03$ & $\mathrm{~Pa}-231$ & $1.00 \mathrm{E}-02$ \\
\hline $\mathrm{Al}-26$ & $1.00 \mathrm{E}-02$ & $\mathrm{~Pb}-210+\mathrm{D}$ & $1.00 \mathrm{E}-02$ \\
\hline Am-241 & $5.00 \mathrm{E}-04$ & Pm-147 & $1.00 \mathrm{E}-03$ \\
\hline $\mathrm{Am}-243+\mathrm{D}$ & $5.00 \mathrm{E}-04$ & Po-210 & $1.00 \mathrm{E}-02$ \\
\hline Au-195 & $5.00 \mathrm{E}-04$ & Pu-238 & 5.00E-04 \\
\hline $\mathrm{Bi}-207$ & $5.00 \mathrm{E}-03$ & Pu-239 & $5.00 \mathrm{E}-04$ \\
\hline C-14 & $9.50 \mathrm{E}-01$ & Pu-240 & 5.00E-04 \\
\hline $\mathrm{Ca}-41$ & $1.00 \mathrm{E}-03$ & $\mathrm{Pu}-241+\mathrm{D}$ & $5.00 \mathrm{E}-04$ \\
\hline $\mathrm{Ca}-45$ & $1.00 \mathrm{E}-03$ & $\mathrm{Pu}-242$ & 5.00E-04 \\
\hline Cd-109 & $1.00 \mathrm{E}-02$ & $\mathrm{Pu}-244+\mathrm{D}$ & 5.00E-04 \\
\hline $\mathrm{Ce}-141$ & $1.00 \mathrm{E}-03$ & $\mathrm{Ra}-226+\mathrm{D}$ & 5.00E-04 \\
\hline $\mathrm{Ce}-144+\mathrm{D}$ & $1.00 \mathrm{E}-03$ & $\mathrm{Ra}-228+\mathrm{D}$ & 5.00E-04 \\
\hline Cf-252 & $1.00 \mathrm{E}-02$ & $\mathrm{Ru}-106+\mathrm{D}$ & $1.00 \mathrm{E}-02$ \\
\hline $\mathrm{Cl}-36$ & $1.00 \mathrm{E}-02$ & S-35 & $5.00 \mathrm{E}-02$ \\
\hline $\mathrm{Cm}-242$ & $1.00 \mathrm{E}-02$ & $\mathrm{Sb}-124$ & $2.00 \mathrm{E}-02$ \\
\hline $\mathrm{Cm}-243$ & $1.00 \mathrm{E}-02$ & $S b-125+D$ & $2.00 \mathrm{E}-02$ \\
\hline $\mathrm{Cm}-244$ & $1.00 \mathrm{E}-02$ & Sc- 46 & 5.00E-04 \\
\hline $\mathrm{Cm}-248$ & $1.00 \mathrm{E}-02$ & Se-75 & $1.00 \mathrm{E}-01$ \\
\hline Co-57 & $1.00 \mathrm{E}-02$ & Sm-147 & $1.00 \mathrm{E}-03$ \\
\hline $\mathrm{Co}-60$ & $1.00 \mathrm{E}-02$ & Sm-151 & $1.00 \mathrm{E}-03$ \\
\hline Cs-134 & $2.00 \mathrm{E}-03$ & Sn-113+D & $1.00 \mathrm{E}-03$ \\
\hline Cs-135 & $2.00 \mathrm{E}-03$ & SI-85 & $1.00 \mathrm{E}-04$ \\
\hline $\mathrm{Cs}-137+\mathrm{D}$ & $2.00 \mathrm{E}-03$ & Sr-89 & $1.00 \mathrm{E}-04$ \\
\hline Eu-152 & $1.00 \mathrm{E}-03$ & Sr $-90+D$ & $1.00 \mathrm{E}-04$ \\
\hline Eu-154 & $1.00 \mathrm{E}-03$ & Ta-182 & $1.00 \mathrm{E}-02$ \\
\hline Eu-155 & $1.00 \mathrm{E}-03$ & Tc-99 & $1.00 \mathrm{E}-01$ \\
\hline $\mathrm{Fe}-55$ & $5.00 \mathrm{E}-03$ & $\mathrm{Te}-125 \mathrm{~m}$ & $1.00 \mathrm{E}-02$ \\
\hline $\mathrm{Fe}-59$ & $5.00 \mathrm{E}-03$ & Th-228+D & $5.00 \mathrm{E}-04$ \\
\hline Gd-152 & $1.00 \mathrm{E}-02$ & Th-229+D & $5.00 \mathrm{E}-04$ \\
\hline Gd-153 & $1.00 \mathrm{E}-02$ & Th-230 & $5.00 \mathrm{E}-04$ \\
\hline $\mathrm{Ge}-68+\mathrm{D}$ & $1.00 \mathrm{E}-02$ & Th-232 & $5.00 \mathrm{E}-04$ \\
\hline $\mathrm{H}-3$ & $9.00 \mathrm{E}-01$ & Tl-204 & $1.00 \mathrm{E}-02$ \\
\hline $\mathrm{I}-125$ & $3.00 \mathrm{E}-01$ & $\mathrm{U}-232$ & $5.00 \mathrm{E}-04$ \\
\hline $\mathrm{I}-129$ & $3.00 \mathrm{E}-01$ & U-233 & $5.00 \mathrm{E}-04$ \\
\hline $\mathrm{Ir}-192$ & $1.00 \mathrm{E}-02$ & U-234 & $5.00 \mathrm{E}-04$ \\
\hline $\mathrm{K}-40$ & $1.00 \mathrm{E}-02$ & $\mathrm{U}-235+\mathrm{D}$ & $5.00 \mathrm{E}-04$ \\
\hline $\mathrm{Mn}-54$ & $2.00 \mathrm{E}-03$ & $\mathrm{U}-236$ & $5.00 \mathrm{E}-04$ \\
\hline $\mathrm{Na}-22$ & $1.00 \mathrm{E}-03$ & $\mathrm{U}-238+\mathrm{D}$ & $5.00 \mathrm{E}-04$ \\
\hline $\mathrm{Nb}-94$ & $1.00 \mathrm{E}-03$ & $\mathrm{Zn}-65$ & $1.00 \mathrm{E}-02$ \\
\hline $\mathrm{Nb}-95$ & $1.00 \mathrm{E}-03$ & $\mathrm{Zn}-95+\mathrm{D}$ & $5.00 \mathrm{E}-04$ \\
\hline $\mathrm{Ni}-59$ & $5.00 \mathrm{E}-03$ & & \\
\hline
\end{tabular}

a Release fractions obtained from Aaberg, R.L., et al. (1995), Radiation Dose Assessment Methodology and Preliminary Dose Estimates to Support U.S. Department of Energy Radiation Control Criteria for Regulated Treatment and Disposal of Hazardous Wastes and Materials, PNL-9405/UC-610, Pacific Northwest Laboratories, Richland, Wash., July. 


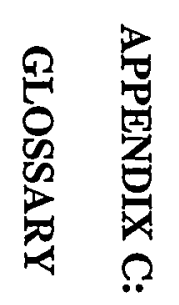


C-2 


\section{APPENDIX C:}

\section{GLOSSARY}

Adjustable parameters. Those parameters that the GUI user can change to more accurately represent the specific TSD facility. The adjustable parameters are originally set to bounding default values.

Bounding (default) parameter values. The most conservative set of parameter values determined from the eight previously assessed TSD facilities.

Clearance. A risk-based process used for determining whether the potentially contaminated DOE waste poses a discernible radiological health risk and for demonstrating to receiving TSD facilities and their regulatory agencies that the waste is safe to accept.

Dose assessment model. A mathematical model to simplify radiological dose calculations for the purpose of assessing consequences to workers and the surrounding public at commercially licensed TSD facilities as a result of receiving and processing slightly radioactive waste.

GUI (graphical user interface). A point-and-click, Windows ${ }^{\circledR}{ }^{\circledR}$-based computer program that simplifies the use of the dose assessment model so that TSD facilities are able to perform calculations with limited outside assistance.

GUI adjustable parameters screens. Seven screens that allow the user to input site-specific information for the seven different operations.

GUI Help. A program feature available for many aspects of the GUI that provides more detail than this report. Because the Help screens are presented in the standard Microsoft format, instructions on their use are not included in this report.

GUI Main Screen. The first screen shown after the title screen; this screen is the base from which all other screens are accessed. It remains in the background when other screens are being accessed.

GUI operations icons. The icons corresponding to the seven different operations; the icons are aligned along the left side of the Main Screen and can be used to toggle operations on/off or to access adjustable parameters screens; the icons are also used in the Receptor Windows to access adjustable parameters screens.

GUI print report. Printed dose results report that shows the highest receptor dose, the other receptors' doses, and a dose breakdown by isotope; the report also lists the values used for the adjustable parameters. 
GUI receptor buttons. Buttons corresponding to the six receptors that are used in the input window to access receptor screens and in the Results Window to access detailed dose reports for each receptor.

GUI receptor screens. Six screens that display the doses from the applicable operations for each receptor and allow the user to access the adjustable parameters screens for those operations.

(Operational) parameters. Set of characteristics such as time and geometry used to mathematically model each operational step.

Potentially contaminated DOE waste. Waste that is currently in storage at DOE sites because of a DOE-imposed shipping moratorium and that was generated through processes that may have resulted in minute radioactive contamination. Radionuclide inventories for these shipments sometimes give worst-case radioactivities derived from the process that generated the waste; hence the term "potentially" contaminated.

Receptors. Theoretical TSD facility workers and off-site receptors used to model exposure to actual receptors.

Reference operations. Seven separate modules that model typical TSD facility operations. Reference operations are building blocks that are combined to more accurately model specific TSD facilities.

Site-specific parameter values. Adjustable parameter values entered by the GUI user to replace default parameter values and to model more accurately the specific TSD facility.

(Operational) steps. Sequential steps that make up each operation and are usually defined by changes of equipment, process, or activity. 